University of Rhode Island

DigitalCommons@URI

Open Access Master's Theses

1995

\title{
ARMY FOR PROGRESS : THE U.S. MILITARIZATION OF THE \\ GUATEMALAN POLITICAL AND SOCIAL CRISIS 1961-1969
}

Michael Donoghue

University of Rhode Island

Follow this and additional works at: https://digitalcommons.uri.edu/theses

\section{Recommended Citation}

Donoghue, Michael, "ARMY FOR PROGRESS : THE U.S. MILITARIZATION OF THE GUATEMALAN POLITICAL AND SOCIAL CRISIS 1961-1969" (1995). Open Access Master's Theses. Paper 1808. https://digitalcommons.uri.edu/theses/1808

This Thesis is brought to you for free and open access by DigitalCommons@URI. It has been accepted for inclusion in Open Access Master's Theses by an authorized administrator of DigitalCommons@URI. For more information, please contact digitalcommons-group@uri.edu. 


\author{
ARMY FOR PROGRESS: THE U.S. MILITARIZATION \\ OF THE GUATEMALAN POLITICAL \\ AND SOCIAL CRISIS 1961-1969 \\ BY \\ MICHAEL E. DONOGHUE
}

A THESIS SUBMITTED IN PARTIAL FULFILLMENT OF THE

REQUIREMENTS FOR THE DEGREE OF

MASTER OF ARTS

IN

HISTORY

UNIVERSITY OF RHODE ISLAND

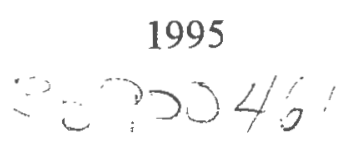




\begin{abstract}
The purpose of this thesis is to explore the military and political implications of the United States' foreign policy towards Guatemala in the years 1961 to 1969. Guatemala was a key battleground of the Cold War in Latin America in the crucial decade of the 1960 s. While greater scholarly attention has focused on the 1954 U.S. backed CIA planned coup in Guatemala, the events of the 1960s proved an equally significant watershed in U.S.-Latin American relations.
\end{abstract}

The outbreak of a nationalist insurgency in Guatemala early in the decade provided the Kennedy Administration with a vital testing ground for its new counter-insurgency and civic action politico-military doctrine. The fear of another Cuba, combined with the growing political and social instability within Guatemala, increasingly drove U.S. policy makers first in the Kennedy and later in the Johnson Administration to adopt a largely military solution in Guatemala just as in South Vietnam with similar tragic results.

Relying primarily on Presidential archival materials, government documents, and Spanish publications as the basis of its analysis, this study demonstrates how 1) the U.S. transmutation of military doctrine and cultures warped civil-military relations within Guatemala, 2) assured the emergence of the Guatemalan military as the dominant force within society, and 3) inadvertently increased the very instability and conflict the U.S. hoped to stem within the region.

This project demonstrates that by the late 1960 s, due in significant part to U.S. 
political and military intervention, the manageable crisis of a small nascent guerrilla movement erupted into an all-out Guatemalan civil war whose tragic consequences reverberate to the present. 


\section{ACKNOWLEDGMENTS}

Several people were instrumental in the preparation and writing of this project. My major professor, Frank Costigliola, provided me with much needed criticism and guidance in the general direction of the work, helping me to frame the thesis, adjust chapter outlines and stay on track when I showed signs early on of veering off course. Of equal importance was his personal kindness, interest and encouragement towards me. Had Frank not sent me to a SHAFR conference at Bentley College in July 1994, I do not think I could have ever written this paper in its present form.

Professor Nancy Bernard cheerfully and amazingly analyzed large amounts of material in a matter of days, pointing out weaknesses and areas $\mathrm{Id}$ neglected all throughout the process, supplying lots of helpful ideas for strengthening the manuscript and rethinking its larger implications.

Professor James Findlay, in addition to reading an early version of the manuscript and pointing out some key problems, was very generous in allowing me time away from my work as his teacher assistant to complete the critical writing of the early drafts. (He also, along with Frank, may go into the Guinness Book of Records for writing the most recommendation letters for a single student in the shortest period of time.)

My cousin, Elizabeth Morais, who teaches Spanish at the Community College of Rhode Island, proved invaluable in deciphering some of the more difficult Spanish publications. My mother Jane provided enormous help in typing considerable sections of the original manuscript. She also supplied a sharp and critical eye towards grammar, 
sentence structure and vocabulary. Marie Rudd of the Interlibrary Loan Department of the URI Library helped in acquiring numerous Spanish publications from the Universities of Texas, New Mexico and Miami Libraries.

The most significant contributor towards the research and writing of this paper came from outside the University of Rhode Island, from Professor Stephen M. Streeter of the University of Connecticut. Stephen, who wrote a masterful dissertation on Guatemala in the 1950 s, is probably one of the five or six leading experts of U.S.-Guatemalan relations in the country. His advice, interest, and generous sharing of archival and Spanish materials proved indispensable to the creation of this paper. He epitomizes all that is best in scholarly collaboration. Stephen pointed me towards all the important secondary literature early on, saving me months of hit and miss investigation. He lent me critical Lyndon Baines Johnson Library documents that I would have otherwise never acquired and cheerfully answered late night calls from me when Id gotten stuck or didn't understand what I was reading. On a personal level, he never treated me as a student but always as a colleague and collaborator. His friendship is one of the pleasant by-products of this thesis. 
Page

ABSTRACT

ACKNOWLEDGMENTS iv

LIST OF TABLES

$\begin{array}{lll}\text { CHAPTER I INTRODUCTION } & 1\end{array}$

$\begin{array}{lll}\text { CHAPTER II } & \text { IMPACT OF THE CUBAN REVOLUTION ON THE } & 8\end{array}$ UNITED STATES MILITARY AND SECURITY ASSISTANCE TO GUATEMALA

CHAPTER III $\quad$ THE KENNEDY DOCTRINE IN GUATEMALA

CHAPTER IV U.S. RESPONSE TO INSURGENCY AND POLITICAL 73 CRISIS IN GUATEMALA 1962-1965

CHAPTER V

VIETNAM ON THE ISTHMUS: THE U.S. LED COUNTER-INSURGENCY WAR IN GUATEMALA 1966-1977

CHAPTER VI

TET COMES TO GUATEMALA: THE URBAN GUERRILLA CRISIS 1967-1969

CHAPTER VII CONCLUSION 


\section{LIST OF TABLES}

TABLE I Comparative Officer Grade Structure -1960

TABLE II Approximate Costs of Military Assistance to Guatemala

TABLE III Annual Budgets of the Public Safety Program, Guatemala 1957-1961

TABLE IV U.S. Assistance to Latin American Police Forces under the Public Safety Program - Fiscal Years 1961-1969

TABLE V U.S. Arms Sales to Guatemalan Police Forces 1961-1969

TABLE VI Special Group (Counter-insurgency)

TABLE VII Counter-insurgency and Civic Action Organization Model for Training

TABLE VIII Central American Graduates United States School of the Americas 1961-1964

TABLE DX Latin American Graduates United States Army Special Warfare Center and School (Fort Bragg) 1961-1963

TABLE X United States Military Aid to Latin America 1952-1963

TABLE XI Military Aid to Guatemala: $1962-1969$

TABLE XII Guatemalan Defense Appropriations 1961-1964 92

TABLE XIII U.S. Military Assistance to Central America Cumulative U.S. Military Aid, U.S. Military Aid per Member of Armed Forces

TABLE XIV March 6, 1966 Guatemalan Presidential Elections

TABLE XV Guatemalan Election Results 1958-1970

TABLE XVI State Department Officials Reassigned from South Vietnam to Guatemala 1964-1972

TABLE XVII CIA Agents Transferred from Vietnam to Guatemala. 


\section{CHAPTER I - INTRODUCTION}

On the night of November 12,1960, two Guatemalan army officers -- Captain Chur del Cid and Colonel Rafael Sessan Pereira -- imprisoned in the Matamoros barracks for acts of rebellion against their government, escaped from their basement cells through the collusion of dissident officers within the Guatemalan Army. While attempting to make their way to a side gate of the barracks, they were spotted by an army colonel and captain who rushed to sound the alarm. Captain Chur del Cid and Colonel Pereira immediately shot both brother officers down at point blank range. With the aid of nearly a hundred fellow conspirators, they quickly seized automatic weapons from the barracks armory, commandeered several jeeps and an armored car, and crashed through the Fort Matamoros' main gate headed for the Atlantic Coast. ${ }^{1}$

This entire incident may have gone down as just another example of what the United States Department of State once referred to as "overheated Central American bravado" $^{12}$ except that the daring Colonel Pereira was a part of a much larger scheme involving over a third of the officers in the Guatemalan Army. The colonel and his co-conspirators were bent on rebellion and not just flight. Arriving in darkness at the important Zacapa military base in northeastern Guatemala, Pereira and his compatriots pretended to be reinforcements and captured the garrison without firing a shot. Most of the soldiers at the base joined the revolt, others fled. Among the escapees was Colonel Ramon Gonzales, the commander of the Zacapa base. Racing along the dirt roads in his favorite English sports car, he reached the sleepy capital, Guatemala City, around dawn and gave the alarm. Military and government officials were stunned and incredulous. 
No one had suspected either a coup or revolt from among the military. The tiny Communist Party and Fidel Castro were the current bogeymen of Guatemalan politics. ${ }^{3}$

While shock and confusion reigned in the capital, Pereira's rebel convoy which had swelled to near battalion size drove on toward the coast, increasing in numbers and enthusiasm at each village along the way. Several of the rebels camped outside the Atlantic port of Puerto Barrios, dressed in campesino garb, posing as rice dealers. The next morning they captured both the base and the port. They executed the colonel in command and began to distribute mimeographed tracts to nearby peasants and fishermen. Some of the pamphlets called for an overthrow of President Ydigoras Fuentes because of his corruption and slavish devotion to the United States; others espoused Marxist and Castroite revolution. Hundreds of peasants presented themselves to the rebels and asked for arms. The Guatemalan navy, consisting of only three vessels -- two of them actually personal yachts of the president -- escaped the capture of its main base and got away from shore in time to notify the capital through radio transmission, confirming the seriousness of the revolt. ${ }^{4}$

A telegram arrived at the State Department from the U.S. embassy in Guatemala City a little after noon on November 13th, 1960. "Some kind of uprising Guatemala City aborted early this morning", began U.S. Ambassador to Guatemala, John J. Muccio. $^{5}$ He then relayed considerably inaccurate and sketchy details of what had occurred so far. His report proved overoptimistic.

By the afternoon of the next day Secretary of State, Christian Herter, apprised President Dwight D. Eisenhower who was vacationing in Augusta, Georgia, of the situation. It was becoming clear to numerous U.S. State Department and diplomatic 
officials that events in Guatemala were spinning "out of control" and required immediate U.S. action. Guatemalan President Miguel Ydigoras Fuentes had been engaged in a drinking bout at his country estate with a number of his colonel friends on the day of the revolt. In his autobiography My War with Communism, he claimed it was "a banquet." He kept calling Ambassador Muccio with alarming reports that Castro was involved in this rebellion, which had meanwhile spread to over a third of the Guatemalan military. Reports of skirmishes between Nicaraguan troops and Cuban "invaders" along the Costa Rican border further flamed U.S. fears. ${ }^{6}$ Complicating matters was the presence of some two thousand Cuban exiles being trained by the CIA for an invasion of Cuba at the La Helvetia plantation of conservative businessman Roberto Alejos in the province of Retalhulen in the remote northwestern region of Guatemala.

By the evening of November 14th, before President Eisenhower even gave orders for U.S. military intervention, the Guatemalan Air Force, as well as Cuban exiles and American CIA pilots flying from secret air bases near the capital, began bombing and strafing the rebels in Puerto Barrios and Zacapa, as a sort of trial run for their later operations in the Bay of Pigs. U.S. transport planes, on Eisenhower's orders, airlifted both Cuban mercenaries and loyal Guatemalan troops to siege lines outside the rebel strongholds. U.S. bombers flying from air bases in the Panama Canal Zone joined the attack. By November 16th, five United States naval vessels, including an aircraft carrier with eighty-five jet fighter-bombers and a 2,000 man strong Marine amphibious group, arrived off Puerto Barrios, supposedly to "interdict a planned Cuban invasion of Guatemala in support of Castroite rebels." ${ }^{7}$ The next day the revolt was finally crushed 
without direct U.S. Marine intervention. Most rebel officers surrendered. Dozens escaped, however, into the countryside where they soon formed the embryo of a guerrilla movement which fights in the Guatemalan jungles to this day. ${ }^{8}$

Although nowhere near as famous as the 1954 U.S. backed CIA planned coup in Guatemala, the revolt of November 13,1960, and its immediate aftermath proved a watershed event for both U.S.-Guatemalan relations and the entire history of Central America. The revolt sparked the first serious insurgency in the Western Hemisphere since Augusto Sandino's war with the United States Marines in Nicaragua in the 1930s. It also elicited a determined reaction from three successive administrations in Washington. Beginning in the 1960 s the United States, primarily in response to the perceived political and economic threat of the Cuban Revolution and this nascent guerrilla movement in Guatemala, began to exert increasing political influence on Guatemalan society, particularly in the areas of military aid, internal security, civic action and counterinsurgency training. Guatemala became a laboratory for the Kennedy Doctrine of nation building and defeating wars of national liberation in Latin America just as Vietnam became the model in Asia. Combined with other internal factors in Guatemalan society, United States military aid and doctrine increasingly polarized politics, warped economic development, repressed democratization and despite the lofty, even sincere, ideals of the Alliance for Progress, helped elevate the Guatemalan military from its traditional role of arbiter among numerous political factions to sole ruler of Guatemalan society. Before the decade ended some 10,000 Guatemalan civilians would lose their lives as a result of these developments. 
This study will examine how political and social crisis first arose in Guatemala in the late 1950 s as a consequence of the 1954 U.S. sponsored coup and the Eisenhower Administration's insistence in maintaining a strong anti-communist bastion in Guatemala. Washington's support for political repression and the crushing of internal dissent provided a key impetus for the later largely nationalist insurgency movement. The 1959 Cuban Revolution heightened the Eisenhower Administration's concerns for further revolutions in Latin America and the Caribbean. Eisenhower's response emphasized internal security and increased military and economic aid to keep Guatemala and other supposedly threatened nations firmly within the capitalist Western fold.

This paper will demonstrate how the Kennedy Administration devised a much more sweeping two pronged strategy for opposing any communist intrusion into its vital Latin American sphere of influence. The Kennedy approach encompassed both Alliance for Progress economic aid and a new counter-insurgency and civic action security program. Guatemala became a prime testing ground for this comprehensive military, ideological, and geopolitical struggle against communism in the Western Hemisphere. The United States brought enormous influence to bear particularly in its championing of the Guatemalan military as the chief agent of stability and change. Washington frequently intervened in the volatile internal politics and social upheaval of Guatemala with often unintended yet almost always tragic results.

When hopes for socio-political reforms and liberal economic development faltered by the mid-1960s, the Johnson Administration with its Mann Doctrine increasingly turned to a strictly military solution in Guatemala strikingly similar to its 
policy in both Vietnam and the Dominican Republic. The short term success of defeating most of the Guatemalan insurgents exacerbated the political climate of terror and fear, and crushed the last hopes for ameliorating the horrendous living conditions, racism and social injustice of Guatemalan society. In attempting to prevent a serious insurgency and social crisis in Guatemala, the United States helped set into place many of the key elements which led directly to both. 


\section{CHAPTER I FOOTNOTES}

${ }^{1}$ Jean Larteguy, Los Guerrilleros. (Mexico City: Raoul Solar, 1970), p. 80; New York Times, November 14, 1960, pp. 3, 9.

2 Holland to Puerifoy, June 30, 1954, Foreign Relations of the United States. (Washington: GPO, 1968), Vol. 4, (1954)., p. 1196.

${ }^{3}$ William Blum, The CIA: A Forgotten Documentary History (London: Zed Books, 1986), p. 164; Alfonso Yurrita, "The Transition from Civilian to Military Rule in Guatemala," from Lewis W. Goodman (ed.), The Military and Democracy in Latin America, (Lexington: Lexington Books, 1990), pp. 77-8.

${ }^{4}$ Michael McClintock, The American Connection, Volume Two; State Terror and Popular Resistance in Guatemala, (London: Zed Books, 1985), p. 49; Stephen M. Streeter, "Managing the Counter Revolution: The United States and Guatemala, 1954-1961," (PhD diss.) University of Connecticut, Storrs, pp. 511-2.

${ }^{5}$ Muccio to Secretary of State Herter, Telegram No. 222, Nov. 13, 1960, Declassified Documents Reference Service (hereafter referred to as DDRS), \#17C.

${ }^{6}$ Miguel Ydigoras Fuentes, My War with Communism, (Englewood Cliffs, N.J.: Prentice-Hall, 1963), pp. 167-169.

${ }^{7}$ International Cooperation Administration, Monthly Report Public Safety Division, Telegram \#3332, Dec. 6, 1960, Washington National Records Center) (hereafter referred to as WNRC), RG 286 Office of Public Safety, (hereafter referred to as OPS), Box 61, folder: Guatemala - Monthly Progress Reports

${ }^{8}$ Susanne Jonas and David Tobis, North American Congress on Latin America: Guatemala, (New York: NACL, 1981), p. 179. 


\section{CHAPTER II}

\section{IMPACT OF THE CUBAN REVOLUTION ON THE UNITED STATES MILITARY AND SECURITY ASSISTANCE TO GUATEMALA}

On the morning of January 1, 1959, Guatemalan President Miguel Ydigoras Fuentes was enjoying the traditional New Year's breakfast of rum, orange juice and tamales when his Foreign Minister Unda Murillo whispered in his ear: "Batista has resigned. He has fled with all his ranking military and political supporters. It appears Castro will run the new government."1

Although neither Ydigoras or his foreign minister seemed particularly alarmed at that moment (nor were most officials in the U.S. embassy in Guatemala City), Castro's revolution would have a profound effect on the politics and internal security of Guatemala for the next two decades. As Castro moved towards socialism and agrarian reform during his first year in power, he increasingly aroused the ire of the Eisenhower Administration, Guatemala's principal benefactor in both economic and military aid. The conflict between Castro and the Kennedy Administration almost led to nuclear war.

The revolution in Cuba represented a serious blow to U.S. economic and strategic interests in Latin America. It also threatened to upset the favorable balance of power the United States had hitherto enjoyed in the Cold War. The containment policies of Truman, Kennan, Acheson and Dulles had been designed primarily for Europe, then expanded to Asia and the Middle East. Communism would be deterred at a safe distance in fairly exotic locales. Yet with a socialist revolt in the Caribbean, the Cold War, for the first time, seriously intruded upon the Western Hemisphere, 
Washington's own backyard and previous "safe zone." Castro's revolution violated two cardinal rules of Washington's Latin American policy. First, by expropriating U.S. property which Castro began in the summer of 1959, it challenged the doctrine of no expropriation without full and immediate compensation that had been the cardinal rule since the start of U.S. economic expansion in Latin America in the 1890s. ${ }^{2}$ Second, in the spring of 1960 Castro crossed the line of acceptable behavior by embracing communism and aligning Cuba with the Soviet Union in direct defiance of the U.S. position, ratified by the OAS, that communism was "incompatible with the institutions and way of life of the Western Hemisphere..$^{13}$ As humiliating and shocking as the Cuban Revolution was to the United States, a far greater threat emerged in the potential spread of Cuban style revolution throughout Latin America. While the United States could countenance the economic and strategic loss of a single island, it understandably feared the exportation of the Cuban model to other countries. Locked in a global struggle with the Soviet Union, successive administrations in Washington viewed the "loss" of any additional Latin American territory as a victory for their mortal enemy. The rise of fidelismo throughout Latin America made it clear that the United States faced an urgent challenge in developing new strategies for dealing with a completely unprecedented situation -- a hemisphere that appeared to be on the verge of revolution. ${ }^{4}$ One of the first places that revolution would break out was Guatemala.

But before the Kennedy Administration developed a larger grand strategy against Castro style Communism in Latin America, the Eisenhower Administration reverted to a more characteristic response to destabilize and overthrow Castro's regime through covert action. This decision would eventually lead to an insurgency in 
Guatemala. As early as November 1959, Eisenhower approved sabotage operations against Cuban sugar refineries, port facilities, and electrical power stations. On March 16, 1960, CIA chief Allen Dulles went a step further in submitting a memorandum to the President entitled "A Program of Covert Action Against the Castro Regime." Its stated objective was "to bring about the replacement of the Castro regime with one more devoted to the true interests of the Cuban people and more acceptable to the U.S., in such a manner as to avoid any appearance of U.S. intervention." ${ }^{15}$ Allen Dulles and Eisenhower were both old hands at this type of clandestine operation, having carried off similar ones in 1953 in Iran against Premier Mossedegh and in 1954 in Guatemala against President Jacobo Arbenz. Revisionist Richard H. Immerman's 1982 The CIA in Guatemala: The Foreign Policy of Intervention is probably the most thorough investigation of theUnited States' role in the 1954 coup to date. Immerman traces a direct link between the 1954 coup and the 1961 Bay of Pigs invasion, conducted in totally different circumstances, yet with the same easy assumption that the CIA could rig a counter-revolution in its favor without directly revealing U.S. involvement. Immerman made extensive use of newly declassified government materials under the Freedom of Information Act, oral histories, National Security Council and State Department memoranda from the Eisenhower Library as well as personal interviews. The one criticism of his work is that it deals almost exclusively with the U.S. side of the coup and its aftermath, and ignored the impact of Guatemalan domestic politics on the coup.

Ironically, the CIA chose Guatemala as the training site for its secret invasion of Cuba, code named Operation Zapata, named oddly for the anti-American, pro-land 
reform hero of the Mexican revolution. Guatemala was in fact the obvious choice as the United States' most pliable ally in the region. In the years 1954-1959 in what amounted to a government salvage job after the economic and social dislocation of the 1954 coup, Washington disbursed some $\$ 110$ million in economic aid to tiny Guatemala. This figure comprised about a third of all U.S. economic aid to Latin America in the period. Having conspired, along with Guatemalan rightists, to overthrow the democratically elected reformist government of President Jacobo Arbenz, the Eisenhower Administration felt duty bound to create a prosperous capitalist showcase state in Guatemala. It encouraged a tripling of U.S. investment in the country, vastly expanded Guatemala's military and totally reorganized the state's internal security apparatus. ${ }^{6}$ Eisenhower's hard line stance in Guatemala reflected a ratcheting up of Cold War tensions around the globe in places as diverse as Iran, Formosa, and South Vietnam by his aggressive Secretary of State John Foster Dulles. Dulles felt that Marxist take-overs could be reversed and cited Guatemala as the first successful example.

In the wake of the 1954 coup, the FBI, CIA and U.S. diplomatic personnel descended on Guatemala to begin instituting a drastic overhaul of the police and security network. In conjunction with Castillo Armas' Liberacion government, they helped establish the Guatemalan National Security Council (modeled after the United States'), the new Department of Security (modeled after the FBI) and the Defense Against Communism Department (modeled after the CIA). CIA personnel and Guatemalan security police drew up a "blacklist" of 70,000 "subversive suspects" from the Arbenz period which would become a primary reference book for government 
associated right wing paramilitary groups throughout the 1960 s. $^{7}$ CIA officer David Philips in The Nightwatch revealed how he and other counter-intelligence officers sorted through Guatemalan records in the mid-1950s:

I returned to Guatemala for a one month temporary duty assignment....as part of a team to assist the new government in sifting and evaluating the documents left behind when Arbenz and his friends abruptly went into the foreign embassies. The papers we found were an intelligence gold mine, filled with nuggets of information...The CI-nicks-counter-intelligence officers -- who worked with me were ecstatic. These were pearls which could be fondled for years. ${ }^{8}$

In 1956, the International Cooperation Administration (ICA) - AID's predecessor instituted the first Office of Public Safety police training program in the Western Hemisphere in Guatemala. FBI and U.S. military advisers strengthened and reorganized the 3,000 man National Police, the secret Judicial Police and the Treasury Guard, Guatemala's Secret Service.' A 1957 Office of Public Safety Memorandum clearly laid out the priorities of this reorganization:

It may be assumed...that the primary police function of protecting life and liberty and preserving the peace is in reality a secondary function of the police administration and executive management. Operations top level planning, intelligence gathering activities are singularly directed towards alertness and preparedness against 'the threat of the communists' instead of being directed against the army of criminals. ${ }^{10}$

Ronald M. Schneider's 1958 orthodox work, Communism in Guatemala, provides a good representation of U.S. fears of communist subversion in the region during the 1950s. But like its 1955 predecessor, Daniel James' Red Design for the Americas: Guatemala Prelude, its scholarship has been called into question for its exaggerated appraisal of the communist threat and its almost exclusive reliance on 
extreme right wing sources and interviews with Castillo Armas' Liberacionista Army veterans. Post-revisionist historian Stephen G. Rabe has even suggested that the CIA helped finance Schneider's study. ${ }^{11}$

Even in this relatively early period, Washington began to view Guatemala as an ideal training ground for the U.S.'s larger security goals in the hemisphere. A 1958 Public Safety memorandum spoke of the director's "pleasure regarding the project for third-country training in Guatemala for Ecuadorians in border control methods and scientific surveillance techniques." The same document went on to cite "joint Guatemalan, Salvadoran and Honduran police training exercises near Guatemala City...."12

Still the government of President Castillo Armas, the U.S. designated leader of the 1954 coup (who had been a furniture salesman in Honduras when the CIA picked him) proved so inept, corrupt and repressive that no amount of American largesse succeeded in halting Guatemala's economic and political slide. When a deranged rightist officer assassinated Castillo Armas in July 1957, several officials in the United States and Guatemalan governments including U.S. ambassador David Sparks, expressed relief. ${ }^{13}$ In the election which quickly followed, massive voter fraud by the ruling party, the National Democratic Movement (MDN) cast doubt on its candidate Miguel Ortiz Pasarelli's victory. When the apparent true winner, Miguel Ydigoras Fuentes, retired general and former Public Works Minister under the ruthless dictator Ubico, protested, Washington supported his call for new elections. An ailing Secretary 
of State John Foster Dulles sought an end to political anarchy in Guatemala, which had increasingly become an embarrassment to United States' prestige. ${ }^{14}$

Ydigoras won a plurality of $42 \%$ in the 1958 elections, running on a platform of nationalism and political reconciliation. His victory was ultimately decided in the National Assembly with considerable arm twisting by the new U.S. ambassador John J. Muccio, who conveyed the Eisenhower Administration's "strong desire for a stable and unified government."15

Ydigoras was therefore somewhat beholden to the United States despite the fact that four years previously th? CIA had rejected him as a potential leader of the coup on the grounds that he was "too headstrong and unpredictable."16 Guatemala owed the United States $\$ 18.2$ million in development loans borrowed between 1955 and 1959 and counted on a similar amount in direct U.S. economic grants for survival each year. In April 1960 when the CIA requested the creation of a secret training base in Guatemala for Cuban exiles bent on invading Cuba, Ydigoras willingly complied. A $\$ 50,000$ personal bribe, combined with $\$ 500,000$ increase in military aid no doubt sweetened the deal. ${ }^{17}$ Ydigoras may have even genuinely relished his involvement in this clandestine attack against Castro. In his autobiography Ydigoras pictured himself as a cold warrior in the most colorful terms:

I fought Castro-Communism from the outset and from the first days of 1959. I was a victim of Fidel Castro's aggression. I frustrated his invasion of Panama in March of 1959; I broke off relations with his government in April of 1960; I withstood two military uprisings inspired by his money and his agents; I cooperated with anti-Castro groups to train 2,000 Cubans and launched them against the Soviet bastion in the Caribbean; I put down an incipient civil war in March, April and May of 1962; I swung a submachine gun around my shoulder in November of 1962 and put down a rebellion of the Guatemalan Air Force. ${ }^{18}$ 
Even members of Ydigoras' own government later admitted much of this was bombast. The plantation La Helvetia owned by the brother of the Guatemalan ambassador to Washington, Carlos Alejos, provided an ideal training site for the Cuban exiles. It was remote yet within B-26 bombing range of Cuba. For insurance, the CIA constructed two new airstrips to support the Cuban invasion on the outskirts of Guatemala City and set up a frogmen training center in Barcenda. Secrets as large as armies and airforces are notoriously difficult to keep -- and word of the operation quickly leaked throughout Guatemala, prompting student protests. On October 30, 1960, the centrist Guatemala City daily La Hora published an article revealing the existence of the camp and the Cuban exiles training there. ${ }^{19}$

Guatemalan officers, especially the younger reformist ones, expressed outrage. According to Turios Lima, a young participant in the revolt and later guerrilla commander, the presence of Cuban exiles training in Guatemala: "was a shameful violation of our national sovereignty. And why was it permitted? Because our government is a puppet. ${ }^{120}$ But he emphasized that his reasons for joining the revolt were essentially "the traditional ones of younger officers fed up with corruption, desiring structural changes in the army, nothing really different." ${ }^{\text {21 }}$

Disgust throughout Guatemala with Ydigoras' corruption was universal. In 1958 as his first official act in office Ydigoras increased his own salary to $\$ 150,000$ a year -- the highest for a head of state in the Western Hemisphere. He also granted himself a generous million dollar pension fund. He appointed his daughter ambassador to France and his cousin education minister. ${ }^{22}$ Auctioning off the national fincas 
(government owned plantations) to whomever offered him the largest bribes. the new president sold offices, as one opponent put it "like a street vendor selling tortillas. ${ }^{.23}$

Ydigoras particularly enraged younger officers by promoting older cronies while obstructing the promotions of lieutenants and captains. He went "colonel crazy" in the late 1950s, jumping favorites several grades, bestowing the rank on civilian bureaucrats and drinking buddies until the Guatemalan Army attained the ludicrous distinction of having $35 \%$ of its officers hold the rank of colonel ( $4.7 \%$ of U.S. army officers in the same time period were colonels).

\section{TABLE $\mathrm{I}^{24}$}

COMPARATIVE OFFICER GRADE STRUCTURE 1960

\begin{tabular}{|c|c|c|c|c|}
\hline \multirow[b]{2}{*}{ Rank } & \multicolumn{3}{|c|}{ (in percentages) } & \multirow[b]{2}{*}{ Panama } \\
\hline & United States & Brazil & Guatemala & \\
\hline General & .4 & 1.0 & 1.0 & 1.0 \\
\hline Colonel & 4.7 & 3.7 & 35.1 & \\
\hline Lt. Colonel & 11.3 & 10.0 & 6.0 & 2.0 \\
\hline Major & 17.4 & 14.8 & 6.0 & 4.0 \\
\hline Captain & 32.9 & 33.0 & 14.0 & 7.0 \\
\hline 1 st Lt. & 18.4 & 26.8 & 15.0 & 32.0 \\
\hline 2nd Lt. & 14.9 & 10.3 & 23.0 & 54.0 \\
\hline
\end{tabular}

In 1960 El Imparcial, Guatemala's most influential newspaper, decried the "lack of discipline [which] increased from top to bottom, consuming social energy and discouraging everyone. ${ }^{125}$ Not all officers, however, were angry at Ydigoras for his graft and demoralization of the military. Several senior colonels expressed resentment that they had not been cut in for their fair share of the $\$ 50,000$ bribe or the $\$ 500,000$ in additional military aid. ${ }^{26}$ 
The Eisenhower Administration's reaction to the rebellion of November 13, 1960, proved swift and decisive. Informed by Secretary of State Christian Herter that the situation was "not good", President Eisenhower decided that "if we received a request from Guatemala for assistance, we would move in without delay."127 Stymied by the breakdown of the Geneva talks with the Soviets over the U-2 Incident and stung by domestic political criticism, blaming his administration for the "loss" of Cuba, Eisenhower was in no mood to equivocate. As in the 1954 coup, American pilots flew combat missions against the rebel bases in American donated planes with Guatemalan airforce markings. In this and other phases of U.S. involvement, Guatemala emerged as a training ground for perfecting CIA covert techniques later used in Laos and Vietnam. Lacking an airforce, pummeled by U.S. B-26 bombers from both Retalhulen and Panama, the rebels' resistance quickly faded. The U.S. naval presence off Puerto Barrios overawed many of the insurgents and clearly dispirited rebel morale. Still the revolt had been a close run thing. Disputed reports from among the participants claimed that Cuban exile troops and not loyal Guatemalan soldiers carried out most of the ground fighting against the insurgents. Ydigoras apparently mistrusted his own troops. ${ }^{28}$ Some 120 Guatemalan army officers and an estimated 3,000 soldiers, over a third of the overall force, participated in the uprising which lasted four days, took over three major military bases and gained control of the country's largest port city. While the revolt started as a nationalist protest against institutional decay and the presence of the Cubans, its bloody outcome further radicalized the survivors. They would return to the country fifteen months later as determined communist guerrillas. Thus in one fell swoop, the United States and Ydigoras eliminated nearly all the young reformist 
idealism within the Guatemalan military. This would be sorely missed when the Kennedy Administration attempted to implement social reforms within Guatemala a year later. ${ }^{29}$

Despite Washington's energetic support on behalf of his regime during the crisis, the United States increasingly pulled away from Ydigoras after the coup. The slow unraveling of Ydigoras' presidency began in November 1960. A 1959 collapse in the price of coffee, Guatemala's number one export, accelerated domestic disillusionment with Ydigoras' economic program. He would flounder desperately in his remaining two and a half years in office, trying to divert attention from his personal malfeasance, political unpopularity and economic failure by alternatively calling for invasions of British Honduras (Belize) and Castro's Cuba as well as overdramatizing his extremely modest land reform program. ${ }^{30}$

After the Cuban Revolution, the Eisenhower Administration began to shift its Guatemalan security policy away from deterring a Moscow-inspired political takeover by a leftist-communist popular front to the suppression of a possible Castro style guerrilla insurgency. Hemispheric defense doctrine, with its emphasis on anti-Soviet submarine surveillance and air patrols, gave way to internal security. ${ }^{31}$ While the Kennedy Administration claimed credit for developing this new strategy in a truly comprehensive fashion, much of its roots really lay in Eisenhower's re-energized Latin American policies in the late 1950s. The 1958 near murder of Vice President Richard Nixon by angry mobs in Caracas, followed by the Cuban Revolution, aroused the administration from its general torpor regarding Latin America with its emphasis on large capital investments, limited military grants, and "trade not aid." The Suez and 
Hungarian crises, the launching of Sputnik, and the 1958 U.S. invasion of Lebanon had tended to keep Washington's attention riveted on the Soviets and the Middle East, not Latin America. By the late fifties, however, the rise of anti-Americanism in the Hemisphere, spurred by U.S. support for dictators, and the fear of "other Cubas" forced Eisenhower to re-evaluate his Latin American policy.

This shift on the security side occurred much earlier in Guatemala when the instability of Castillo Armas' post 1954 coup government required a heavy emphasis on internal surveillance and police repression of "all hostile political elements." It remained doubtful just how powerful these "elements" that included a handful of communists, peasant labor leaders, university professors and students, actually were. Certainly, the temptation of Guatemalan political leaders to use this largely American fashioned security apparatus for their own dictatorial purposes proved overwhelming. The security build-up in Guatemala served as a model for similar expansions in other Latin American nations implemented at the end of the decade. A foreign service dispatch of September 1959, from the American Embassy in Guatemala to the State Department traced the history of U.S. military involvement throughout the decade and highlighted the fluctuations of disbursements:

Guatemala has been the recipient of exclusive aid under the Mutual Security Program. In addition to moderate military assistance and the existence of an Army Mission and an Air Mission, some $\$ 58,000,000$ has been made available during the past five years as technical and Special Assistance. This was a consequence of the need to bolster the economy and strengthen the democratic regime which followed the overthrow in 1954 of the Communist-dominated Arbenz Government. 
The allocation of funds have been as follows:

TABLE $\Pi^{32}$

\section{APPROXIMATE COSTS}

(In Thousands)

\begin{tabular}{ccccc}
$\begin{array}{c}\text { Army Mission Including } \\
\text { Military Assistance }\end{array}$ & Air & ICA & & $\begin{array}{c}\text { (Construction of Inter- } \\
\text { American Highway) }\end{array}$ \\
\hline
\end{tabular}

1953

1954

1955

1956

1957

1958

1959

1960

$\$ 67$
68
68
688
237
170
239
313

$\$ 60$

64

71

77

78

93

135

$\begin{array}{rrr}\$ 1,814 & \$ 8,039 & \$ 70 \\ 1,833 & 12,681 & 2,902 \\ 2,189 & 15,423 & 8,845 \\ 2,226 & 10,250 & 9,440 \\ 2,708 & 423 & 2,375 \\ 2,400 & 70 & 3,500\end{array}$

Military assistance to the Army Mission (column \#1), which included training and equipment, was minimal during the years of the Arbenz presidency, 1953 and 1954. In fiscal year 1956, aid increased by about $1,000 \%$. This occurred in conjunction with the massive overhaul of Guatemalan military and security forces (police, secret police, and the new security departments), by U.S. Army, CIA and FBI advisors. A gradual fall-off of investment then occurred which began to rise noticeably again during the Castro years 1959 and 1960. During the years of this admittedly uneven build-up, the Guatemalan Army increased in size by $60 \%$, from 5,000 to 8,000 men. The Guatemalan National Police increased by $50 \%$ from 2,000 to 3,000 men. The Public Safety Program records show similar patterns of U.S. investment. 
Table III $^{33}$

ANNUAL BUDGETS OF THE PUBLIC

SAFETY PROGRAM, GUATEMALA 1957-1961

\begin{tabular}{cccccc}
\multicolumn{7}{c}{ (US thousands) } \\
FIRST YEAR & TOTAL & TECH & PART & COMMOD & OTHER \\
57 & 280 & 38 & 0 & 242 & 0 \\
58 & 158 & 58 & 37 & 58 & 5 \\
59 & 72 & 53 & 13 & 0 & 6 \\
60 & 267 & 37 & 1 & 219 & 10 \\
61 & 271 & 35 & 11 & 213 & 12
\end{tabular}

The United States made a large initial investment to set up the program and reinvigorate Guatemalan police and internal security. A drop-off followed, but again the advent of Castro brought about a nearly $400 \%$ increase in funding between FY 1959 and FY1960 which continued into FY1961. It is important to note that no tables of CIA or FBI spending in Guatemala have been declassified to date, though one can assume their spending patterns approximated those of Military Assistance and the Office of Public Safety. It is known that the CIA under both Eisenhower and Kennedy spent $\$ 11$ million setting up various Cuban exile bases and training programs in Guatemala between April 1960 and April 1961. ${ }^{34}$ Political scientists and human rights activists, Susanne Jonas and Michael McClintock, in their works The Battle for Guatemala (1991) and The American Connection (1985) make a strong argument that the roots of all political repression in Guatemala lay in these crucial Eisenhower years of the mid to late 1950 s, but this study will show that the Kennedy influence in the early 1960s was even more pronounced and predominant. 
One of the ironic outcomes of the Eisenhower Administration's increased military assistance, intelligence and internal security spending in Guatemala was that the network it helped install seemed to know everything that was going on inside of the country except the fact that one-third of the military was about to rise up and overthrow the government. Much of this was due to both Washington and the Guatemalan government's obsession with the small Guatemalan Communist party as the only credible threat to the government.

In hindsight the appraisal made in this internal Office of Public Safety memo, dated June 20, 1960, speaks volumes of the U.S. misappraisal:

The extent to which military assistance can, by strengthening Guatemala, aid U.S. national security and our foreign policy interests is perceptible but of a rather diverse nature. As of now it is doubtful if Guatemala could be of much help outside the confines of its own frontiers. There is however gradually being engendered a better understanding of free world ideology, a better esprit de corps, and hopefully, we think, slightly less political ambition on the part of those trained in the military. It is true there remains a large group of older senior officers who would like to be President, but junior officers are now learning something about simple military devotion to duty. Training in U.S. service schools has positive benefits not only in the military sense but also has observably had very considerable desirable moral influence on those who have passed through them ${ }^{35}$

Four months later the Guatemalan military erupted in revolt led almost exclusively by junior officers, most trained in U.S. service schools, all under the age of thirty. The memorandum was correct in stating that a majority of these officers had a strong moral devotion to duty, yet that devotion led them to oppose, not endorse, the security policies of the United States.

"Castro changed everything," asserted Captain Thomas "Rip" Robertson, former rodeo rider and CIA pilot who took part in both the 1954 Guatemalan coup and the 
1960 crushing of the rebels. "We were in a whole new ballgame and our pitching was pretty wild the first couple of years." ${ }^{36}$

It would fall to the Kennedy Administration to try and pick up the pieces of a fairly botched U.S. economic and security policy in Guatemala. The new administration would crystallize the doctrine which dominated U.S. policy in Guatemala for the remainder of the decade. 


\section{CHAPTER I FOOTNOTES}

${ }^{1}$ Miguel Ydigoras Fuentes, My War with Communism . (Englewood Cliffs, N.J.: Prentice Hall, 1963), p. 1.

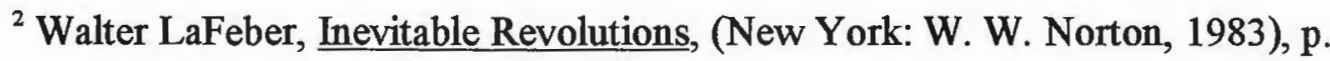
107.

3 "The Caracas Declaration", Department of State Bulletin 31, (March 31, 1954), p. 211.

${ }^{4}$ Louise Fitz Simmons, The Kennedy Doctrine, (New York: Random House, 1973), p. 19.

${ }^{5}$ John Prados, The Presidents' Secret Wars: CIA and Pentagon Covert Operations Since World War II, (New York: William and Morrow, 1986), p. 178.

${ }^{6}$ Susanne Jonas and David Tobis, eds., Guatemala, (New York: North American Congress on Latin American Press, 1981) p. 58.

${ }^{7}$ Michael McClintock, The American Connection Vol. II: State Terror and Popular Resistance in Guatemala, (London: Zed Books, 1985), p.34.

${ }^{8}$ David Atlee Phillips, The Night Watch, (London: Robert Hale, 1978), p. 52.

${ }^{9}$ McClintock, The American Connection, p. 36.

${ }^{10}$ ICA Report on the National Police of Guatemala, Washington National Records Center (hereafter referred as WNRC), Office of Public Safety Records, Box 60, Folder: Guatemala Programs 1955-1958 (hereafter referred to as OPS) .

${ }^{11}$ Stephen G. Rabe, "Clues Didn't Check Out: Commentary on the CIA and Castillo Armas," Journal of Diplomatic History, Vol. 14, No. 1 (Winter 1990), p. 93.

12 "Guatemala Public Safety Matters", September 27, 1957, WNRC, RG 286, OPS Box 60, Folder: Guatemala Programs 1955-1958.

${ }^{13}$ Sparks to Dulles, July 27, 1957, Foreign Relations of the United States: The American Republics (hereafter referred to as FRUS), (Washington, D.C.: Government Printing Office, 1983), Vol. 4, p. 472.

${ }^{14}$ Dulles to Sparks, October 23, 1957, FRUS, 1955-1957, Vol. 4, p. 491.

${ }^{15}$ Dulles to Muccio, March 18, 1958, FRUS, 1958-1960, Vol. 5, p. 389.

${ }^{16}$ Peurifoy to Department of State, May 12, 1954, FRUS, Vol. 4, p. 1096. 
${ }^{17} \mathrm{Jim}$ Handy, Gift of the Devil: A History of Guatemala, (Boston: South End Press, 1984), p. 153.

${ }^{18}$ Ydigoras, My War With Communism, p. 2.

${ }^{19}$ La Hora, October 30, 1960, pp. 1, 12.

${ }^{20}$ Turcios Lima to Alan Howard, "With the Guerrillas in Guatemala," New York Times, June 26, 1966, p. 20.

${ }^{21} \underline{\text { Ibid, }}$ p. 20.

${ }^{22}$ James Sloane, "The Electoral Game in Guatemala,", $(\mathrm{PhD}$ diss., University of Pittsburgh, 1968), p. 93.

${ }^{23}$ La Hora, October 30, 1960, pp. 1, 10.

${ }^{24}$ Cesar D. Sereseres, "Military Development and the U.S. Military Assistance Program for Latin America,", (PhD diss.), University of California, Riverside, 1971, p. 109.

${ }^{25}$ El Imparcial, Nov. 18, 1961, p. 12.

${ }^{26}$ James Dunkerly, Power in the Isthmus: A Political History of Modern Central America, (London: Verso, 1988), pp. 441-2.

${ }^{27}$ Dwight D. Eisenhower, Waging Peace, (Garden City: Doubleday, 1965), p. 613.

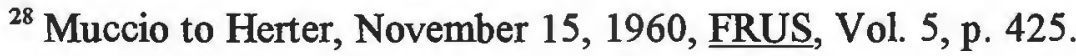

${ }^{29}$ Bruce Minoff, Pragmatic Illusions: The Presidential Politics of John F. Kennedy, (New York David McKay, 1976), p. 118.

${ }^{30}$ Thomas and Marjorie Melville, Guatemala: The Politics of Land Reform, (New York: Free Press, 1971), pp. 128-133.

31 "Latin American Defense Policy", John F. Kennedy Library, National Security Files, Department of Defense Joint Chiefs of State, Vol. 1, Box 276, Folder: Military Action for Latin America.

${ }^{32}$ Foreign Service Dispatch \#168, September 21, 1959, WNRCN, RG 286, OPS, Box 60, Folder: Guatemala, General.

${ }^{33}$ Office of Public Safety, Termination Phase-Out Study, (Washington, DC: Government Printing Office, 1975), p. 148.

${ }^{34}$ John Prados, The Presidents' Secret Wars, p. 187. 
35 "Military Assistance to Guatemala," June 20, 1960, WNRC, RG 287, OPS, Box 61, Folder: Guatemala, General.

${ }^{36}$ Robertson to the author, Prados, The Presidents' Secret Wars, p. 183. 


\section{CHAPTER III}

\section{THE KENNEDY DOCTRINE IN GUATEMALA 1961-1963}

"For the first time in our history an enemy stands poised at the throat of the United States," candidate John F. Kennedy told a veterans' convention at Miami Beach on August 26, 1960. "Castro's ambitions extend far beyond his own shores. He has transformed the island of Cuba into a hostile and militant Communist satellite -- a base from which to carry Communist infiltration and subversion throughout the Americas..." In January, 1961, the same month the new president took the oath of office, Premier Nikita Khrushchev delivered a speech to the meeting of International Communist Parties in Moscow, in which he pledged the Soviet Union's support for "wars of national liberation" around the globe. A representative of the Guatemalan Communist Party (the PGT) attended this meeting. But the Kennedy Administration had no intention of countenancing Guatemala's "liberation."

The Kennedy Administration arrived in Washington in January 1961, with a throng of what were later referred to as "action intellectuals" ready to propose and implement a host of new foreign policy initiatives designed to roll back and defeat Communist revolution throughout the Third World. Early hagiographic accounts, such as Arthur Schlesinger, Jr.'s 1965 A Thousand Days, pictured Kennedy and his advisors as sober, reflective, dedicated knights-errants. But as revisionist historians, such as Thomas G. Paterson, in his 1989 Kennedy's Quest for Victory point out, the new president and his close inner circle placed a premium on toughness, energy, drive and vigor, on an aggressive "hands-on can do" approach to foreign policy. They regarded 
Eisenhower's recent Cold War diplomacy, particularly in Latin America, as soft, uninspired and lethargic. "We have allowed a soft sentimentation to form the atmosphere we breathe," Kennedy claimed "toughminded plans have to be designed."

Kennedy regarded Latin America as an area of supreme geo-political importance only superseded by the direct conflict with the Soviets in Europe. With much fanfare, he proposed an "Alliance For Progress" in March of 1961, an ambitious $\$ 20$ billion aid program for Latin America over ten years. While the Eisenhower Administration had already put forward a somewhat similar increase in Latin American aid at the Bogota Convention in 1960, the Alliance for Progress promised to do far more. It encompassed "a vast cooperative effort unparalleled in magnitude and nobility of purpose, to satisfy the basic needs of the American peoples for homes, work and land, health and schools..." ${ }^{13}$

This new partnership of North and South would embrace both economic development and social restructuring. It included national planning and technical aid, agrarian and tax reform, public housing, education, health care -- a veritable cornucopia of social reforms and improvements. All this would supposedly operate within the framework of democratic institutions, proving "the compatibility of representative government with material progress." Harking back to Jefferson and Bolivar, Kennedy cloaked these ideas with the mantle of revolution: "Let us once again transform the American continent into a vast crucible of revolutionary ideas and efforts..." ${ }^{4}$

Central to the Alliance for Progress, though never mentioned by name, was a more recent revolution -- the Cuban one of Fidel Castro. "It was," Ronald Steel observed in Pax Americana "neither charity nor a guilty conscience but Fidel Castro 
who provided the inspiration for the Alliance for Progress...[it] might never have seen the light of day, let alone grow into a childhood, had Fidel not injected the fear of Communism into official Washington." 5

Less than a month after the announcement of this grand new initiative, the ghastly failure of the U.S. backed Bay of Pigs Invasion doused cold water on Kennedy's initial enthusiasm for redrawing the political and social parameters of Latin America. Yet the seriousness of its Cuban failure only emphasized the administration's desire to achieve some kind of success south of the border. It proved telling that the man who had come up with the phrase "Alliance for Progress" and would help put the program together, Kennedy aide and Harvard graduate Richard Goodwin, (twenty-nine years old at the time) had never been to South America. ${ }^{6}$ Kennedy's ideology and energy almost immediately ran up against the harsh political and social reality of Latin America.

Guatemala, one of the highest per capita recipients of Alliance for Progress aid in the 1960s illustrated just how stark Latin American reality could be. In 1961 Guatemala had a basically two crop export economy consisting of coffee and bananas, $90 \%$ of which were sold to the United States for very low, largely U.S. determined, prices. On the other hand, Guatemala purchased $80 \%$ of its imports -- staple grains, manufactured goods, machinery and equipment -- from the United States at relatively high U.S. prices. The result was an unfavorable balance of payments and an almost classic neo-colonial dependency on the United States. ${ }^{7}$ 
Guatemalan society, like most of Latin Americas, was sharply stratified along rigid, almost feudal, class lines. The criollos, affluent land owners of Spanish and other European ancestry, comprising about $2 \%$ of the population, owned $70 \%$ of the land. Most of the senior, high-ranking military officers either came from or identified with this class. Together with wealthy businessmen and foreign investors the criollos dominated Guatemala's economy and politics. Politically they aligned themselves with the right-wing National Liberation Movement (MLN), Castillo Armas' reactionary, fiercely anti-Communist political party. ${ }^{8}$

A larger middle class group of mixed Spanish and Indian ancestry, the ladinos made up around $40 \%$ of the population and owned about $20 \%$ of Guatemala's land. Largely urban, shopkeepers, craftsmen, managers, low level government functionaries, as well as some small farmers, the ladinos were an important force in the more modern sectors of the Guatemalan economy and supplied the Guatemalan military with most of its junior officer corps. The majority, but not all, allied themselves with the liberal centrist Revolutionary Party (PR). The Kennedy Administration counted on these ladinos to lead the way towards the modernization and democratization of Guatemala. ${ }^{9}$

The largest population group in Guatemala in 1961, making up about 55\% of the roughly four million population, were impoverished Maya Indians. They owned less than $10 \%$ of the land and were virtual serfs forced by law to work 150 days a year for starvation wages on the vast coffee, banana and cotton plantations of the criollos. Largely disenfranchised, $80 \%$ illiterate, with a life expectancy of forty-two, an infant mortality rate of $40 \%$ and an average per capita income of $\$ 63$ a year (compared to $\$ 181$ for the average Guatemalan), the Indians of Guatemala remained completely 
isolated from the political life of the country. Worse, they were subject to a centuries old form of racism and discrimination. With their very different Amerindian looks, clothing, language, customs and religion, the Maya represented the ever present "demonic other" of Guatemalan society. Through over four hundred years of Spanish domination, they endured expulsion, massacres and economic dehumanization. ${ }^{10}$ As one Spanish plantation owner said in a telling comment on both racism and upper-class opposition to modernity: "Why spend ten thousand dollars for a tractor when you can get Indians to work for seventy-five cents a day?"11

This almost incredibly inequitable political-economic structure of Guatemala posed a huge obstacle to the Alliance for Progress, which the Kennedy Administration never really overcame. Yet while the Eisenhower White House never even attempted to change and, in fact, reinforced this status quo, the crusaders of the New Frontier, actually made a stab at it. The already relatively high economic aid to Guatemala increased by over $40 \%$ in the early 1960 s to about $\$ 25$ million per year. This expansion of aid was based in part on the Alliance for Progress' favoritism towards "constitutional governments" in Latin America. The Kennedy Administration cut aid to numerous notorious dictators in the region such as the Dominican Republic's Trujillo and Haiti's Duvalier. Kennedy hoped to encourage democratization by rewarding more moderate and democratic regimes like Betancourt's in Venezuela and Frondizi's in Argentina. In January 1961 the Kennedy Administration refused to recognize a military junta which had recently seized power in El Salvador. Such lofty principles, like much of the rhetoric of the Alliance for Progress, did not last long. Still, in early 1961 hopes for the Alliance ran high. 
In a wave of initial optimism and idealism scores of Peace Corp Volunteers and Maryknoll missionaries arrived in Guatemala, setting up peasant cooperatives and local improvement projects. United States Agency for International Development (AID) loans, both large and small, multiplied as well as credits from the Inter-American Development Bank (IDB), the Inter-American Bank of Rural Development (IBRD) and the Export-Import Bank. ,Guatemala received staple grains and dairy products from Food for Peace and private contributions from CARE and Project Hope. ${ }^{12}$

The bulk of the larger economic loans and grants to Guatemala, however, like practically all Alliance for Progress aid, were "tied loans." This meant that the dollar loans or grants had to be spent on purchasing American goods and services. In effect the Export-Import Bank and AID used taxpayers' money to subsidize the growth of large American companies that did business with Guatemala. Guatemala's U.S. purchases were often made at prices $30 \%-50 \%$ above world market prices so that, in real terms, the value of the aid was little more than half the nominal amount. Moreover, goods which Guatemala bought within the framework of this "not-quite-aid" were typically second rate. American freighters transported goods to Guatemala which could no longer be sold on the U.S. market -- obsolete machinery, antiquated vehicles and machine tools. (The same procedure existed with U.S. military sales to Guatemala. The U.S. military unloaded much of its obsolescent equipment on Guatemala at high U.S. prices.) Worse still, the Hickenlooper Amendment to the 1962 Foreign Assistance Act, drawn up in reaction to Castro's seizure of U.S. property in Cuba, called for the automatic suspension of U.S. aid to any country "which expropriated or 
nationalized the property of U.S. citizens. ${ }^{113}$ Foreign and international loans to Guatemala held the same stipulation. Thus, Alliance for Progress aid, meant supposedly to develop and reform Guatemalan society, by its very nature forbade the equitable reform and redistribution of Guatemala's land and resources. In 1960, U.S. and foreign companies owned nearly $40 \%$ of Guatemala's arable land They also held claim to the vast majority of its natural resources -- oil, nickel, tungsten, iron, timber and natural gas. In the early 1960 s, $\$ 92$ million of the $\$ 117$ million of foreign investment in Guatemala came from the United States. By 1964, Guatemala imported $\$ 38$ million more than it exported and \$36 million of this unfavorable balance of payments was with the United States. ${ }^{14}$

The majority of large Alliance for Progress development projects helped neither Indians nor middling Guatemalan businessmen and farmers. The huge $\$ 12$ million Rio Hondo Road Project, begun with much publicity by the Kennedy Administration in 1961, provided a prime example of Alliance for Progress aid in Guatemala. The project connected the main Atlantic port of Puerto Barrios with Honduras. The Guatemalan government had to pay the $\$ 12$ million in principal plus roughly $\$ 5$ million in interest back to the United States in dollars, which placed a heavy burden on Guatemala's balance of payments. The Guatemalan government purchased all the machinery for construction from the United States under the terms of the loan. The engineer, contractors, supervisors and surveyors were all from United States companies. Three U.S. firms -- Nebloteer, Poteshnick and Harrison, paved and constructed the road. The highway itself largely facilitated the shipment of export crops -- coffee, bananas and cotton, not from individual farmers but from large plantations. ${ }^{15}$ U.S. AID loans built 
similar roads north to the mineral and oil extraction enterprises of American and foreign investors. The Rio Hondo project drove numerous Indian families, that had the bad fortune to be located in its path, off their land with little compensation. All these newly constructed roads provided access for the Guatemala military in their new U.S. built trucks, jeeps and armored cars to reach remote hinterlands where guerrillas operated. Most of the road projects of the Kennedy era in Guatemala traveled through guerrilla country. Little wonder many embittered Guatemalan Indians referred to the Alliance for Progress as Alianza para el Progresso - The Alliance Stops Progress. ${ }^{16}$ Much of the historiography of the Alliance captures the disillusionment with the program in its very titles: Victor Alba's 1965 Alliance Without Allies, Jerome Levinson and Juan de Onis' 1970 The Alliance That Lost Its Way, Robert Smetherman's 1972 The Alliance for Progress: Promises Unfulfilled.

The Kennedy Administration's economic program in Guatemala operated on the assumption that there was a connection between poverty and political instability which would inevitably lead to Communism. But as political scientist Lucien Pye and others pointed out, this was not necessarily the case. ${ }^{17}$ Economic development was probably a greater cause of social instability than simple economic deprivation in Guatemala. The Alliance for Progress unleashed a torrent of investments, loans, grants, rural projects, industrial enterprises, peasant cooperatives, road building, local improvement campaigns, free clinics, bribery, extortion, land grabbing, price fixing, forced expulsions and general socio-economic chaos. As the Yankee dollars poured in, the de-stabilization of society and the exploitation of the poor increased. Peasant cooperatives and credit unions, set up by Peace Corps volunteers, enraged local 
plantation owners because they made the campesinos less dependent on the criollos. When American AFL-CIO volunteers handed out Spanish translations of the Declaration of Independence to labor unions, Guatemala businessmen protested vociferously against the distribution of Communist propaganda. Food for Peace milk and cheese undercut Guatemalan dairy farmers. When the Peace Corps built schools in the countryside, less Indian children reported for work on cotton plantations. ${ }^{18}$ The Guatemalan oligarchy and the Kennedy Administration were clearly speaking two different languages in early 1961. Jean-Francois Revel captured something of this quandry when he stated: "The idea that an authoritarian political system must collapse because it cannot provide a decent life for its citizenry can only occur to a democrat... The notion that whoever holds power must clear out because his subjects are discontented or dying of hunger or distress is a bit of whimsy that history has tolerated few times in real life. ${ }^{119}$

The Alliance for Progress brought about a huge rise in expectations to the poor of Guatemala which upset the traditional social fabric much more than Castro's largely annoying radio broadcasts. Wealthy Guatemalans certainly regarded Kennedy, with his wild ideas of land reform and progressive tax codes, as a much greater threat to their position than Castro. As one landowner put it, "When the Cubans come I can shoot them but I can't shoot these damned Americans. ${ }^{20}$ One of the great unintended results of the Alliance for Progress in Guatemala was that it helped fuel the very insurgency it was designed to defeat. Capitalist democracy in a society as feudal as Guatemala represented, a truly revolutionary idea. Yet having raised expectations of individual prosperity, the program failed miserably to deliver on them. The great majority of 
funding still went to the larger development projects which inevitably benefited U.S. investors and Guatemalan elites. Peasant social reforms and local improvement projects, on the other hand, barely scratched the surface of deep, systemic, century old inequities. $^{21}$

Was another alternative available to the Kennedy Administration to truly modernize and democratize Guatemala? Numerous tracts of land could have been redistributed among the Indians. A larger amount of government loans and private investment could have been targeted to small businesses and domestic manufacturing. But such a course of real reform would have infuriated the Guatemalan oligarchy and substantial elements of the military, the United States' only real allies in Guatemala. It also would have hurt U.S. corporations' and investors' profits. Such a scheme would also weaken the political dependence of Guatemala on the United States at a time when the Kennedy Administration attempted to forge strong U.S. dominated military and economic alliances throughout Central American as a wedge against Castro. The Kennedy Administration faced a fundamental dilemma early on in Guatemala. It could either have chronic instability, wedded to political and economic dependence or an independent, semi-socialist state in Guatemala. As much as the Kennedy Administration claimed to dislike the former, it clearly preferred it to the latter.

The Kennedy Administration's reform program in Guatemala can best be evaluated in its approach to the vital land issue. Just as 19th century black sharecroppers in the United States could never hope to gain any real political power until they first owned their own land, so two-thirds of the Guatemala population remained forever isolated, embittered and marginalized, simply because they did not 
own enough land to feed themselves. Large scale coffee, banana and cotton production for export soared during the Alliance for Progress years, almost in direct proportion to malnutrition, unemployment, infant mortality, disease and demoralization among the Indian and poor ladino population. ${ }^{22}$ Mayas would literally die of starvation while hauling hundred and fifty pound banana stems on their backs fourteen hours a day. In 1961, one YMCA volunteer walked away in shock when he discovered 5,000 Indians living in rat infested tin and stucco housing on a coffee plantation with a total of six open water faucets and no medical facilities. ${ }^{23}$ From 1961 to 1964 the Gross National Product of Guatemala rose an average of $5.5 \%$ a year -- a higher growth rate than the United States in the same period, yet income among the lower $60 \%$ of the Guatemalan population actually dropped $14 \%{ }^{24} \quad$ "Guatemala," as Marxist journalist Eduardo Galeano remarked, "was developing itself into its grave. ${ }^{125}$ Or as Riguberta Menchu, a peasant Maya woman put it, "These people don't care. For these people an Indian is less than a dog. ${ }^{126}$

In 1961 under pressure from the Kennedy Administration Guatemala's president Miguel Ydigoras Fuentes finally initiated his long awaited land redistribution program. He decided his government should dispose of some 132 national fincas (government owned plantations) expropriated from Germans during World War II and from former Ubico and Arbenz supporters. Ydigoras held several elaborate, ribbon cutting ceremonies, attended by U.S. embassy officials, in which he distributed 12 of the 132 fincas to landless Indians to be divided into numerous family plots. He sold the remaining 120 fincas to wealthy landowners and a number of his own relatives, pocketing much of the profits. ${ }^{27}$ Ambassador John O. Bell called the effort "a good first 
step. ${ }^{128}$ For his agricultural minister during the Kennedy years, Ydigoras appointed Pedro Mombiela, one of Guatemala's richest cattle barons. Like most Guatemalan cattle ranchers, Minister Mombiela had created his vast grazing empire by expelling Indians at gun point from their traditional holdings. Guatemalan U.S. AID director, Herbert Hardin, said that Mombiela has "a number of interesting ideas in the areas of land reform. ${ }^{129}$ One of his brainstorms was colonization. Mombiela distributed tracts of impassable, mountainous jungle lands in the northernmost province of Peten on which, as one peasant remembered, "God couldn't grow a carrot," to incredulous Indians chosen by lottery. Some of these areas were so remote "a jaguar couldn't reach them ${ }^{130}$ Government helicopters dropped off the lucky owners along with some lumber and a few hand tools. The hardy individuals among them managed to hack their way back to civilization with machetes. Those less resourceful were left to the vultures. ${ }^{31}$ The Inter-American Bank of Rural Development director in Guatemala wrote: "There have been some problems with the government's new overambitious resettlement schemes. ${ }^{132}$

In his five years in office Ydigoras redistributed land to 2,451 Indian families. In 1953-4 President Arbenz, who was overthrown by the CIA, redistributed land to some 100,000 Indians. One idealistic U.S. businessman, Patrick A. Mulvey, became so frustrated with the Kennedy Administration's failure to push land reform in Guatemala, that he hatched the idea of the U.S. government, through third parties, simply buying up $\$ 40$ million dollars worth of land and then redistributing it to peasants on its own. As he wrote, the mere mention of land reform in Guatemala "sets off the red flag of Communism among wealthy businessmen. ${ }^{1133}$ The White House shelved Mulvey's idea 
as "an interference in the internal affairs of Guatemala." Melville's 1971 Guatemala: The Politics of Land Reform is one of the earliest revisionist works on economic and social inequality in Guatemala. Written during the height of the Vietnam War by two former Maryknoll missionaries, who shocked the State Department by joining the guerrillas, their study comprehensively examines the failure of agrarian reform with particular emphasis on Guatemalan sources. The Melvilles correctly appraise land reform as the acid test of democratization in Guatemala, which both the U.S. and all Guatemalan governments since Arbenz failed. They also convincingly demonstrate that the 70 year alliance between the Guatemalan oligarchy, U.S. investors, and the U.S military effectively quashed all reform efforts whether they emanated from Guatemala or Washington.

With the road to social progress increasingly blocked by local elites and the United States' own reluctance to force through meaningful change, the main emphasis of the Kennedy Doctrine in Guatemala shifted quite early from reform to repression. Almost from day one, the Kennedy Administration established the primacy of internal security, of holding the line against Communist and leftist agitation while or until supposedly enlightened elements with Guatemalan society would implement social reforms. National Security Action Memorandum 34, dated February 20, 1961, laid out the four point security program which would dominate Kennedy policy in Guatemala. It sharply reflected a military emphasis.

1. The Defense Department has taken steps to unify the various Service Missions in each Latin American country into a single MAAG (military Assistance Advisory Group) under the command of Commander 
in Chief Caribbean Command (CINCARIB).

2. AID is engaged in reviewing the Public Safety Program for Latin America to insure that it is highly responsive to the critical needs of each Latin American country for police assistance and surveillance of hostile elements.

3. Pursuant to NSAM 19, AID and the Defense Department are acting jointly in the development of civic action projects, additional to those now underway, that might usefully be undertaken in Latin America.

4. Pursuant to NSAM 18, an expanded program of close collaboration between the U.S. and Latin American military in areas of training, equipment and tactical indoctrination is currently underway. ${ }^{35}$

These became the pillars of U.S. policy in Latin America as a whole. In the early 1960s the Kennedy White House moved away from President Eisenhower's program of unconventional covert war against undesirable governments (Mossadegh's Iran, Arbenz's Guatemala) towards a policy of both overt_and covert war against the internal enemies of friendly governments such as South Vietnam and Guatemala. U.S. trained anti-guerrilla fighters would defeat local insurgents that plagued U.S. allies. Kennedy's new counter-insurgency program initially turned the foreign policy establishment on its ear with a flurry of seminars, counter-insurgency courses, bureaucratic upheavals "and an almost frantic formulation of unfamiliar policy" ${ }^{\text {"36 }}$ Some of this actually had a comic aspect as plump, middle aged foreign service veterans donned jungle gear while observing Green Beret exercises. The traditional American military service chiefs resisted what they regarded as the "crackpot aspects" of this new "we have to be guerrillas to defeat the guerrillas" doctrine, but gradually, albeit reluctantly, they got on board especially after each service was guaranteed its own sexy, new COIN outfit. ${ }^{37}$ 
History provides numerous examples of novel, ground breaking military doctrines, which events prove to be dead wrong: Doubet's theory of strategic bombing, the British early twentieth century battleship mania, and French Defense Minister Andre Maginot's state of the art, high-tech defensive line, to name a few. While the jury may still be out on the Kennedy Doctrine of Counter-insurgency, it seems destined to join this list of strategic "white elephants." Michael McClintock's 1992 Instruments of Statecraft provides one of the latest and most sweeping studies of U.S. counter-insurgency warfare in the post World War Two era. McClintock reveals that, while the Kennedys were aware of the broader socio-political parameters of Third World guerrilla warfare, they still judged the threat to be amenable to a technical fix. McClintock gives rather short shrift of the Kennedys' understanding of the political nature of insurgency, that it was a response to colonialism and socio-economic injustice, but his work is indispensable in chronicling the military development of this doctrine, dating back as far as the Filipino Revolt of 1899-1902. Like his earlier 1985 American Connection, McClintock's Instruments of Statecraft draws heavily upon declassified and leaked Department of Defense, FBI, and CIA sources. Both books are sharply critical of U.S. policy and full of valuable data and insights on how ideology can shape military doctrine and vice-versa.

As far back as the early 1950s, John F. Kennedy expressed the belief that Soviet sponsored brushfire warfare represented the gravest threat to the world balance of power. He felt the United States had to counteract it with a new kind of anti-guerrilla warfare, especially in Latin America, where the threat of social revolution loomed large. Drawing on the lessons of the few successful counter-insurgency campaigns, 
those of Sir Robert Thompson in Malaya and Edward Lansdale against the Huks in the Philippines, Kennedy began formulating his new "Special Warfare" strategy. Ironically, former French paratroop generals like Francois Massu, supplied much of the counter-insurgency inspiration to the Kennedy Administration from articles in the Revue Militaire D'Information. ${ }^{38}$ What most observers failed to note was that these same French officers had lost their own counter-insurgency campaigns first in Indo-China and later in Algeria, using these exact, highly acclaimed yet wrong headed theories.

The first principle of the Kennedy Administration's counter-insurgency strategy in Guatemala was to avoid the use of large conventional American ground forces. Except for Green Beret advisers, Army technicians and trainers, Guatemalans were to fight Guatemalans. Thus Vietnamization came to Guatemala eight years before President Nixon implemented it in Vietnam. As a March 20, 1961 Department of Defense Memorandum stated: "A well trained indigenous force can better counter the Communist threat and propaganda than the larger powers. At least our hand will not be apparent. Our biggest assistance can come through the Military Assistance Advisory Groups (MAAG) if they are provided with the doctrine for anti-guerrilla counter-subversion and are given clear political goals. ${ }^{139}$

On May 25, 1961 Kennedy addressed the entire nation before a Joint Session of Congress, devoting considerable time to the Communist insurgency crisis. In words riven with irony, he expressed as much the U.S. program in Vietnam and Guatemala as the supposed Soviet threat it was designed to defeat:

...their aggression is more often concealed than open. They have fired no missiles, and their troops are seldom seen. They send arms, agitators, aid, 
technicians, and propaganda to every troubled area. But where fighting is required, it is usually done by others, by guerrillas striking at night, by assassins striking alone...by subversives, saboteurs and insurrectionists, who in some cases control whole areas inside of independent nations. ${ }^{40}$

With few credible insurgencies in the hemisphere in early 1961 Kennedy initially took a keen interest in Latin American police training. In National Security Action Memorandum No. 88, dated September 5, 1961, he called for additional "steps...to train the Armed Forces and Police Forces of Latin America in controlling mobs, and rioters...Also what other steps are we taking to increase the intimacy between our Armed forces and the military of Latin America? It has been suggested that we set up a camp in the United States similar to the FBI Academy which brings in police from all over the Americas. ${ }^{141}$

The United States had been training Latin American police officers in a haphazard, country by country fashion since the 1940s. In 1962 at Kennedy's insistence, the United States created the Inter- American Police Academy in the Panama Canal Zone. ${ }^{42}$ In late 1963 the school changed its name to the International Police Academy (IPA) and moved to Washington, D.C. Spanish speaking, retired American police and FBI officers taught the standard eight week general course which covered finger printing techniques, surveillance, riot control, interrogation, incarceration and criminal record keeping methods. During the 1960 s, 452 Guatemalan police officers graduated from the academy. The Guatemalan police acquired an unsavory reputation for corruption dating back to the 1950s. Office of Public Safety memos reported rapes, opium smuggling and the frequent torture of suspects. One report stated that suspects were often held between "ninety days and four years before being charged with 
crimes. $^{\text {nq3 }}$ U.S. sponsored police training emphasized both professionalization and moderation to solve these problems. In 1962 Assistant Secretary of State, Edwin Martin, noted that:

In assessing the internal security situation in Latin America we found that civil police forces in many countries needed assistance in police administration, training and operational techniques and particularly required greater mobility and more adequate systems of communication largely related to riot control and other threats to public order. Consequently the public safety program, which is an integral part of the AID program, is designed to meet these requests. ${ }^{44}$

Through the Office of Public Safety Program, the Kennedy Administration supplied the Guatemalan police with helicopters, computers, radios, armored cars and machine guns. It furnished the police with millions of rounds of small arms ammunition, thousands of revolvers, shotguns, tear gas grenades, riot batons, shields and helmets, hundreds of walkie-talkies, police cars and wagons, gas masks and bullet proof vests. ${ }^{45}$ Students from San Carlos University, as well as labor unions and leftist political parties, frequently demonstrated against the government during the Kennedy years and the Administration wanted always to be fully prepared. As former AID Administrator David Bell testified before Congress in 1963:

The police are the most sensitive point of contact between the government and the people, close to the focal points of unrest and better trained and equipped than even military in

most cases to deal with both major and minor forms of violence, conspiracy, and subversion. ${ }^{46}$

In the opening paragraph of the International Police Academy's catalogue, the Office of Public Safety stated that of all its programs "training has the most enduring 
effect." ${ }^{147}$ While Academy spokesmen characterized the school's course material as dealing exclusively with "those modern techniques of law enforcement necessary to maintain an effective, responsive and humane police force, ${ }^{148}$ counter-insurgency and political warfare constituted a considerable part of all instruction, according to the academy's own published curriculum. Lectures, such as "The Threat to Latin America," "Communism in the Caribbean" and "The Enemy Within," indicated the ideological flavor of this supposedly unbiased, strictly professional, training. ${ }^{49}$

Public Safety Advisers in Guatemala furnished in-country police training as well. Each adviser put together a team of top IPA graduates, high ranking senior Guatemalan police, as well as U.S. military police personnel from the American Embassy's MAAG Army mission to conduct police training seminars throughout Guatemala. The Office of Public Safety's in-country advisory staff, like all American security programs in Guatemala, was relatively large. From two political advisers in 1961, the OPS mission grew to four by 1965 and seven by 1969 , making it the largest contingent in Latin America. (See table below.)

\section{TABLE IV ${ }^{50}$}

US ASSISTANCE TO LATIN AMERICAN POLICE FORCES UNDER THE PUBLIC SAFETY

PROGRAM - FISCAL YEARS 1961 - 1969

(Current U.S. dollars, in thousands)

$\begin{array}{lccc}\text { Argentina } & 120 & 78 & 2 \\ \text { Bolivia } & 2,325 & 64 & 2 \\ \text { Brazil } & 8,612 & 570 & 1 \\ \text { Chile } & 2,386 & 163 & -- \\ \text { Columbia } & 6,944 & 448 & 5 \\ \text { Costa Rica } & 1,921 & 160 & 4 \\ \text { Dominican Republic } & 4,193 & 204 & 3 \\ \text { Ecuador } & 3,915 & 160 & 3\end{array}$


Total Expenditures Students Trained in the US US Public Safety Advisors

\begin{tabular}{lrrr} 
El Salvador & 2,092 & 168 & $\mathbf{1}$ \\
Guatemala & $\underline{\mathbf{4 , 8 5 5}}$ & $\underline{\mathbf{4 6 2}}$ & $\mathbf{7}$ \\
Honduras & 1,741 & 105 & $\mathbf{3}$ \\
Jamaica & 780 & 92 & $\mathbf{1}$ \\
Mexico & 745 & 34 & -- \\
Nicaragua & 315 & 81 & 2 \\
Panama & 2,148 & 202 & 3 \\
Paraguay & --- & 23 & -- \\
Peru & 4,142 & 110 & - \\
Uruguay & 2,209 & 173 & 4 \\
Venezuela & 3,625 & 541 & 4 \\
Other/Regions & 2,239 & 36 & - \\
\multicolumn{1}{c}{ TOTAL } & 55,307 & 3,874 & 45
\end{tabular}

While the OPS mission was still relatively small compared to the U.S. military mission, it remained vital due to its strategic placement at the heart of the Guatemalan police apparatus. OPS advisors and their associate personnel trained, directed and indoctrinated thousands of Guatemalan rank and file police officers. According to AID figures the in-country training program involved some 30,000 Guatemalan police during the decade of the 1960 s, making it the largest in Latin America. ${ }^{51}$ In-country training covered urban and rural patrolling operations, vehicle and equipment maintenance, the tracking of suspected subversives, communication, intelligence, and the "implementation of modern scientific aids," (torture). ${ }^{52}$

The Guatemalan National Police Force expanded dramatically during this period of intensive U.S. training and modernization. From 3,000 men in 1961 it grew to 4,500 in 1965 and to 6,500 by 1968 . Due to their sensitive nature, many of these figures may only be fragmentary. The Guatemala government employed numerous "reservists" and 
"assistants" during periods of terrorist crises in the 1960s. Part of the OPS training and indoctrination of the Guatemalan National Police included the Kennedy counter-insurgency doctrine of employing "associated friendly paramilitary forces to help support embattled free world governments. ${ }^{153}$ Both the Guatemala military and police maintained close links to rural and urban paramilitary squads throughout the 1960s. These right wing groups frequently consisted of retired or reserve police and Army officers joined typically by plantation overseers and factory foremen employed by the Guatemala oligarchy. Because of the sensitive nature of these groups and the danger of their activities smearing the reputation of the U.S. Office of Public Safety, the program itself rarely provided them with arms. Instead, the Guatemala police purchased weaponry for them through private arms sales with U.S. manufacturing firms. (See table below.)

TABLE $V^{34}$

US ARMS SALES TO GUATEMALAN POLICE FORCES 1961-1969

\begin{tabular}{|c|c|}
\hline Quantity & Products \\
\hline 75,000 rds & $\mathrm{FC} .45 \mathrm{cal}$ ammo \\
\hline $\begin{array}{c}100,000 \text { rds } \\
120\end{array}$ & $\begin{array}{l}\text { FC ammo(Army } 380045 \mathrm{cal} \text {.) } \\
\text { SW } .38 \text { cal. revolvers }\end{array}$ \\
\hline $\begin{array}{r}120 \\
75\end{array}$ & $\begin{array}{l}\text { SW } .22 \mathrm{cal} . \text { revolvers } \\
\text { CI } .38 \mathrm{cal} . \text { revolvers }\end{array}$ \\
\hline 640 & CI $.38 \mathrm{cal}$. revolvers \\
\hline 167,000 rds & $\begin{array}{c}\text { WI ammo }(.388, .222, .270 \\
.32, .22,25, .38 \mathrm{cal} .)\end{array}$ \\
\hline $\begin{array}{c}65 \\
100\end{array}$ & $\begin{array}{l}\text { WI rifles } \\
S W .38 \text { cal. revolvers }\end{array}$ \\
\hline $650,000 \mathrm{rds}$ & $\begin{array}{c}\text { WI ammo }(.22, .25, .32 \\
.78, .380 \mathrm{cal} .)\end{array}$ \\
\hline
\end{tabular}

Importer
Jones Aircraft \& Arms
-New York, NY
Licen
Smith \& Wesson
-Springfield, MA
Colt Industries
-New York, NY
"
Jones Aircraft \& Arms
-New York, NY
Winchester Industries
-Hartford, CT
"
Smith \& Wesson
-Springfield, MA
License Date Recipient 6/61 Police Use

9/61 Police Use

12/61 Judicial Police

6/62 Judicial Police

6/93 National Police

12/63 National Police

6/64 National Police

9/64 Treasury Police

3/65 National Police

6/65 Judicial Police

9/65 Treasury Police

12/65 National Police 


\section{(TABLE V continued)}

\begin{tabular}{|c|c|c|c|c|}
\hline Quantity & Products & Importer & License Date & e $\underline{\text { Recipient }}$ \\
\hline 2,500 & $\begin{array}{l}\text { AA MPG-100 CNgas } \\
\text { grenades }\end{array}$ & AAI Corp-Baltimore, $\mathrm{MD}$ & $2 / 66$ & National Police \\
\hline 2,500 & AA MPG-100 C gas grenades & " & $2 / 66$ & National Police \\
\hline 200 & SW .38 cal. revolvers & $\begin{array}{l}\text { Smith \& Wesson } \\
\text { - Springfield, MA }\end{array}$ & $10 / 67$ & Judicial Police \\
\hline 150 & CI $.38 \mathrm{cal}$. revolvers & $\begin{array}{l}\text { Colt Industries } \\
\text {-New York, NY }\end{array}$ & $12 / 67$ & National Police \\
\hline 150 & CI .22 cal. pistols/revolvers & 20 20 & $3 / 68$ & Treasury Police \\
\hline 345,400 rds & $\begin{array}{c}\text { WI ammo }(.22, .243, .250 \\
.270,38 \text { cal. })\end{array}$ & $\begin{array}{l}\text { Winchester Industries } \\
\text {-Hartford, CT }\end{array}$ & $3 / 68$ & National Police \\
\hline 120 & SW .38 cal. revolvers & $\begin{array}{l}\text { Smith \& Wesson } \\
\text {-Springfield, MA }\end{array}$ & $12 / 68$ & Treasury Police \\
\hline 300 & CI .38 revolvers & $\begin{array}{l}\text { Colt Industries } \\
\text {-New York, NY }\end{array}$ & $3 / 69$ & National Police \\
\hline 250 & CI .22 pistols/revolvers & $"$ & $4 / 69$ & Judicial Police \\
\hline
\end{tabular}

During crisis periods in the early 1960s, the United States frequently rushed additional special purpose police equipment on U.S. Army transport planes directly to Guatemala City. Some of this equipment was similar to that of the Soviet Bloc. A March 15, 1962, memorandum to the President stated:

Contrary to the impression in a cable from Guatemala City this morning, most of the internal security equipment which has been approved has been delivered. Two items, sickening gas and two water tank trucks were not initially approved because it was not thought desirable to associate the United States with these patently repressive instruments. As a substitute new tank trucks, which incidentally must be procured in Germany and are of the type used by the Soviets and East Germans along the Berlin Wall (author's italics) have been sent and are now in Guatemala City...5

It is ironic that John F. Kennedy, famous for his 1963 speech at the Berlin Wall condemning Communist tyranny against the people of Eastern Europe, used the exact same instruments of repression against college students and labor unions in Guatemala. This classified document is also indicative of Kennedy's keen interest in the internal 
security of Latin American nations. One would not ordinarily suppose that a U.S. president would be concerned with such detailed minutia as the type of crowd control equipment employed against rioters in Guatemala City.

Civic action provided another keystone to the Kennedy Doctrine in Guatemala and particularly emphasized the notion of "winning the hearts and minds" of the Guatemalan people as well as vigorously promoting the concept of "nation building." The Pentagon defined civic action as:

the use of preponderantly indigenous military forces on projects useful to the local population at all levels in such fields as education, training, public works, agriculture, transportation, communication, health, sanitation and others contributing to economic and social development which would also serve to improve the standing of the military forces with the population. ${ }^{56}$

Several questions arise from the definition itself. By its very nature civic action contained an imperialist connotation. It consisted largely of bringing civilization to the natives. The whole concept was externally imposed like most Alliance for Progress programs. It also embodied a militarist solution. Under civic action the military became the chief agent of economic development in the countryside, not civilian government agencies or the peasants themselves. The third question to ask is why does the indigenous military's standing with the population need to be improved? The answer was that in most of the Third Word countries where the United States employed civic action, the military had a terrible reputation as the violent gendarme of the unjust status quo. This was certainly the case in Guatemala where the appearance of soldiers in Indian villages touched off panic -- and for good reason. Civic action 
therefore involved the concept of having soldiers with few economic skills attempt to bring material prosperity to people who hated them.

Since civic action neatly tied together both the military and economic components of the Alliance for Progress, the Kennedy Administration enthusiastically pushed it as a kind of panacea for the socio-political problems of Latin America. In his March 13, 1961, Alliance for Progress speech President Kennedy stated: "And the new generation of military leaders has shown an increasing awareness that armies can not only defend their countries -- they can as we have learned through our own Corps of Engineers, help to build them. ${ }^{157}$ Unlike counter-insurgency, civic action had the advantage of being far more palatable to elements of the Congress that remained skeptical of Kennedy's militaristic approach to Latin America. Senator George Aiken of the Senate Foreign Relations Committee expressed these sentiments when he spoke to Secretary of Defense Robert McNamara.

I have been concerned as I know you have over the past years, Mr. Secretary, lest we provide the means for arming one Latin American country against another -- or against their own people. I know we have both expressed a hope that there will be more conversion to engineering battalions and other phases of the military besides that of being strictly policemen. And I am glad to hear you report what progress is being made. ${ }^{58}$

Normally the Civil Action portion of a Military Assistance Program (MAP) grant was in the area of $10-15 \%$. (In Guatemala in the early 1960 s it averaged $12 \%$.) But this $10-15 \%$ greatly eased the Congressional passage of MAP grants to dictatorial regimes. Administration officials "talked up" the benefits of the Civic Action portion of military assistance while they publicly down played the more unsavory aspect of counter-insurgency and Office of Public Safety funding which really made up the lion's 
share of grants. The opposite was true in classified documents where State Department and CIA personnel rarely emphasized Civic Action as a workable solution to the crisis in Guatemala.

The United States sent its very first Civic Action Mobile Training Team (CAMTT) to Guatemala in November 1960. Guatemala served as a sort of guinea pig for virtually all of Washington's Latin American security initiatives in this period. At first the program was designed to have a very "low cost", almost "no cost" budgetary profile. The U.S. would simply provide training and the Guatemalan military would pick up the tab for improving its nation's infrastructure. In 1961 the Kennedy Administration expanded funding dramatically from the $\$ 75,000$ the Eisenhower Administration provided to $\$ 310,000{ }^{60}$ President Ydigoras expressed immense enthusiasm for this new version of military assistance. Unpopular at the time, he saw civic action as a vehicle to improve his image. The Guatemalan civic action program was unique from all others in Latin America in that the United States Civic Action coordinator acted solely as an advisor. As part of the deal to allow it to be tested in their country, the Guatemalan military controlled and conducted the entire program. Both U.S. Army Mission and AID officials complained of this, fearing the notoriously corrupt Ydigoras might siphon off funding. Indeed for the amount of money and equipment disbursed, the Guatemalan Army did not complete that many projects.

Civic action in Guatemala focused on a limited number of irrigation projects, dispensary services, road building, school construction, water purification and sanitation and communication improvements. As with several large AID projects many of these had a dual civilian-military purpose. In accordance with U.S. military doctrine, the 
Guatemalan military carried out the majority of its civic action programs in the most disaffected regions of the countryside, Zacapa and Izabal where the rebel movement flourished. ${ }^{61}$

The problems that resulted from the Guatemalan civic action program illustrated some of the basic weaknesses and contradictions of the Alliance for Progress and the Kennedy Doctrine in general. Supposed altruism engendered resentment from all sides. Peasants and Indians expressed suspicion over these projects, particularly road building and the laying of telephone lines in guerrilla areas. In the past, government school and road construction always employed local Indian labor, providing desperately needed income to the rural poor. Now the Guatemalan Army carried out the majority of these construction projects, eliminating civilian jobs. This also angered local ladino construction firm owners. Large landowners complained that irrigation projects made the Indian more self-reliant and less apt to report to work on their plantations. Landowners regarded civic action built school houses with particular anathema. "Once an Indian can read you can never get him to work...he becomes lazy... no good," one stated in Barizan after the military erected a new school house. ${ }^{62}$

Indian and peasant workers felt they could build schools and clinics more cheaply and efficiently than the Army. They pointed to shoddy construction, inflated costs, and graft at virtually every civic action site. Soldiers invariably sold left-over construction materials to local businessmen. Many officers in the Guatemalan Army infused with machismo and a centuries old warrior code deeply resented having to play the part of "glorified construction workers." They felt it denigrated their stature as soldiers to swing picks and shovels. With guerrillas operating openly in the 
countryside, civic action programs seemed superfluous to them, their job was to kill the enemies of the state. Talented ambitious officers avoided civic action duty. Incompetent, corrupt ones generally ran the program. ${ }^{63}$

Because of its relatively low budget, $\$ 300,000-\$ 500,000$ per year in the 1960 s (though some of this was supplemented with Guatemalan funds), the U.S.-Guatemalan Civic Action Program had a showcase atmosphere to it. Isolated projects furnished excellent ribbon cutting photo opportunities for U.S. and Guatemalan political and military leaders. "A lot of it was a publicity gimmick," Peace Corp worker Gerald McGetrick noted. ${ }^{64}$ Indeed in 1963 some $20 \%$ of the U.S. Civic Action budget in Guatemala went to such ceremonies, receptions and brochure publications, detailing the accomplishments of Civic Action in Guatemala. ${ }^{65}$ The project never really made much of a dent in the horrendous poverty of the countryside which by 1964 was the second worst in the Hemisphere after Haiti. Bringing more soldiers into contact with peasants and Indians did not have the beneficial effect Kennedy Administration officials hoped for either. Guatemala officers could barely conceal their contempt for Indians even while they worked among them. Stuck in isolated villages for weeks at a time, they often raped Indian women and confiscated food and drink. Questionable polls (conducted in virtually occupied villages) showed only a slight increase in respect for the military among the populace during the projects which rapidly eroded once the soldiers left. Peasants became cynical. "You have to have a guerrilla unit nearby to get drinking water," one said. ${ }^{66}$ President Ydigoras liked to throw handfuls of candy at Indian children while visiting civic action sites in perhaps a fitting metaphor for the whole program. ${ }^{67}$ Guerrilla fighter Hernandez Mayen, a witness to U.S.-Guatemalan 
civic action as a child, said: "I was glad that the Army built the school, but I would have liked it better if they had killed all the landlords. ${ }^{168}$

If the Kennedy Administration could not win the "hearts and minds" of Guatemalan peasants, it was determined to win over those of the Guatemalan military. By early 1962, the White House translated the intellectual theory of counter-insurgency into a comprehensive bureaucratic program. In January, 1962, National Security Memorandum 124 established the Special Group (Counter-insurgency) as a permanent part of the administration's national security apparatus (See table below)

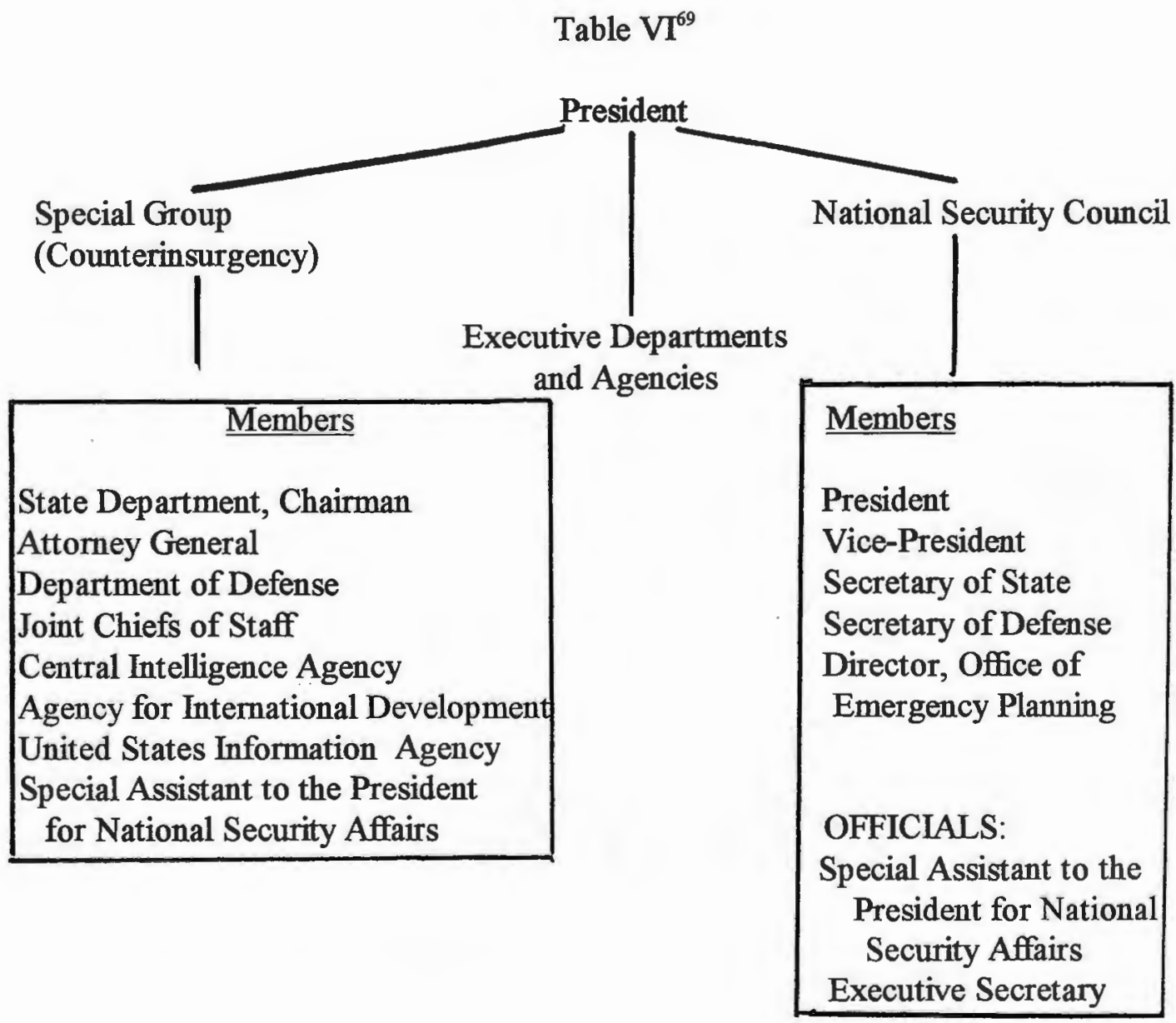


The Special Group, which met every Thursday afternoon in the Executive Office Building, centered on formulating security policy for several designated target countries. Though numerous other countries were later added in 1962 only four here mentioned by name in National Security Memorandum 124 -- Laos, Thailand, South Vietnam and Guatemala., When asked how trouble spots were singled out, Deputy Secretary of Defense Roswell Gilpatric replied:

Well, usually either State of CIA or once in a while AID or Defense would come up with a program which some desk officer had honed in on. It wasn't a very scientific process...It really reflected what was happening in the world at a particular time and what particular area offices were interested in... ${ }^{70}$

This Special Group (Counter-insurgency) structure proved important because it was duplicated at the U.S. Embassy in Guatemala City (and many others) with Special Group (Counter-insurgency) Country Teams. These comprised the chief representatives of the embassy, the military attaches, the USIA, the AID, the CIA, military missions (or MAAGs) and other agencies represented in Guatemala. The Guatemalan Special Group Country Team met frequently under the close supervision and leadership of the Ambassador, John O. Bell. ${ }^{71}$ This whole process further militarized U.S. embassies. Instead of being diplomats, ambassadors like Bell became quasi-military leaders. The whole concept of counter- insurgency contained a conspirational, cloak and dagger flavor which appealed to the Kennedy sense of style. 
The very concept helped lead ambassadors like Bell into clandestine midnight meetings with the Guatemalan military and opposition political leaders, ever deeper into the internal affairs and political morass of Guatemala. The cult of counter-insurgency encouraged an underhanded, manipulative approach to foreign relations. "Every member of the embassy bęcame an operative. We really started to think that we could control events in what was really an uncontrollable society," ${ }^{172}$ one official in the Guatemalan embassy later admitted. The Kennedy Administration's entire view of the world was that of a giant conspiracy which could only be mastered from great centers of power.

Before an actual guerrilla movement erupted in February 1962, the Guatemalan counter-insurgency program focused mainly on training the Guatemalan army in preparation for this new style warfare. The Department of Defense erected a complex new counter-insurgency bureaucracy to match the White House's which reached down from the Pentagon to the lowest individual Guatemalan conscript. (See table on next page. ) 
TABLE $\mathrm{VII}^{73}$

COUNTER-INSURGENCY AND CIVIC ACTION

ORGANIZATION MODEL FOR TRAINING

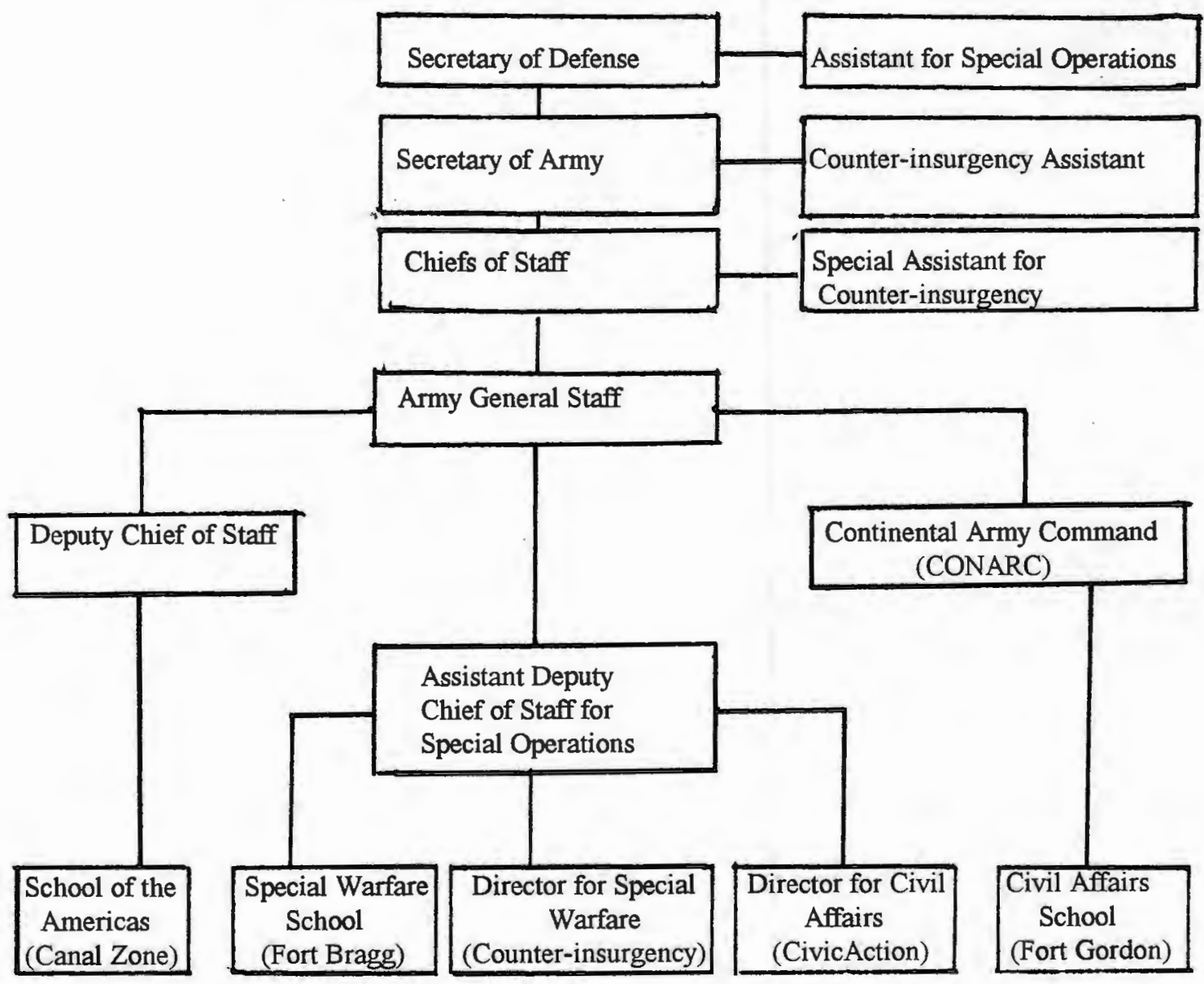

The majority of out-of-country counter-insurgency training for Guatemalan officers and enlisted men took place at the U.S. Army Caribbean School in Panama, renamed the United States School of the Americas on July 1, 1963. President Kennedy placed particular emphasis on this school, vastly increasing its faculty, training facilities, curriculum, and enrollment. ${ }^{74}$ The school's normal student load at one time consisted of about 500 Latin American students (as opposed to 90 during the Eisenhower years). 
and specialists from the United States military though Latin American officers also took part. The school had two instructional departments -- the internal security department and the technical department. The former's course work was taught almost exclusively in Spanish and included counter-insurgency operations, military intelligence, military police, command and staff, infantry operations, jungle warfare, and airborne assault. The department, according to its own handbook, provided "instruction in every aspect of counter-insurgency:, military, paramilitary, political, sociological, and psychological." ${ }^{175}$ The school provided additional jungle training for Guatemalan cadets at the United States Air Force Tropical Survival School located a the nearby Albrook Airbase in the Canal Zone. The U.S. Army's Eighth Special Forces Group which Kennedy permanently deployed to Panama in 1962 supplied instructors. ${ }^{76}$ The table below shows the number of Guatemalan graduates from the School of the Americas 1961-1964, approximating the Kennedy years.

\begin{tabular}{lc}
\multicolumn{2}{c}{ TABLE VII $^{77}$} \\
Central American Graduates \\
United States School of the Americas & $1961-1964$ \\
& \\
Country & Number \\
\hline Costa Rica & 1,639 \\
El Salvador & 358 \\
Guatemala & 958 \\
Honduras & 810 \\
Nicaragua & 2,969 \\
Panama & 1,420 \\
\hline TOTAL FOR CENTRAL AMERICA & 8,154 \\
TOTAL FOR LATIN AMERICA & 16,343
\end{tabular}


Guatemala did not represent the highest number of graduates, largely because alone of all the Central American countries, it maintained a U.S. Green Beret operated counter-insurgency training base on its own territory, secretly established in Maricos in May, 1962. By then Guatemala, unlike her sister republics, did not need to ship so many officers and enlisted men to Panama for the latest, up-to-date instruction. Also of note in the chart is the fact that nearly half of all Western Hemisphere School of the Americas graduates came from Central America even though their nations represented only a tiny percentage of the total Latin American population. The proximity of the region to both Cuba and the United States, plus the budding insurgency in Guatemala, heightened the Kennedy White House's security concerns for the region. Walter LaFeber, one of the leading revisionist historians on U.S.-Central American relations, refers to the U.S. School of the Americas as the School of Golpes (coups) in his 1984 work Inevitable Revolutions. A Mexican official remarked: "Give me the names of the first 60 students and I'll pick your presidents in Latin America for the next 10 years." ${ }^{178}$ Indeed, numerous officers trained there led revolts against democratically elected governments in their home countries. While the Kennedy Administration initially hoped to graduate professional, democratic minded young officers from these huge academies, the emphasis on anti-communist ideology and counter-insurgency turned out a throng of authoritarian rightists. Worse, their activities increased anti-Americanism throughout the Hemisphere. These new Kennedy trained Latin American soldiers wore United States-style uniforms, insignia, and helmets, carried United States weapons, and in the case of Guatemala, were led by United States advisors. Who they represented was all too apparent to embittered, impoverished campesinos. 
The cream of the Guatemalan young officer corps received further out-of-country U.S. counter-insurgency instruction at the U.S. Army Special Warfare Center and School at Fort Bragg, North Carolina. Unlike the School of the Americas, the Fort Bragg facility furnished training for primarily American troops and officers. The United States bestowed a particular badge of honor on the select Latin American officers (usually the brightest of their own service academies) that it invited to this school. $^{79}$ (See table below.)

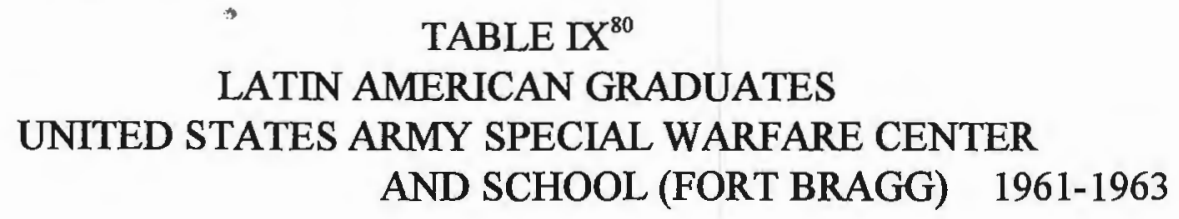

\begin{tabular}{lr} 
Country & Num \\
Argentina & 19 \\
Bolivia & 23 \\
Brazil & 2 \\
Chile & 6 \\
Colombia & 5 \\
Costa Rica & 1 \\
Ecuador & 14 \\
El Salvador & 1 \\
Guatemala & $\underline{13}$ \\
\hline Haiti & 1 \\
Honduras & 1 \\
Mexico & 3 \\
Nicaragua & 8 \\
Peru & 4 \\
Venezuela & $\underline{11}$ \\
TOTAL & 112
\end{tabular}

Again for a country of only four million, Guatemala's 13 graduates indicate a disproportionate representation. Graduates from this elite center invariably rose high in the ranks of the Guatemalan military to command positions and political office (Lucas Garcia and Rios Montt, presidents of Guatemala from 1978-1982 and 1982- 1983 respectively, both attended this school in the early 1960 s). ${ }^{81}$ 
The United States also trained selected Guatemalan officers in civic action at the Army Civil Affairs School at Fort Gordon, Georgia; in close support and napalm bombing at the United States Air Force School at Albrook Air Base in the Canal Zone, in Air Force Special Operations at the Air Commando School at Howard Air Force Base in the Canal Zone and at the Special Air Warfare Center (SAWC) at Elgin Air Force Base, Florida. ${ }^{82}$

In 1962 on Presidęnt Kennedy's expressed recommendation, an Inter-American Defense College was established at Fort Lesley McNair in Washington, DC from which 16 Guatemalan cadets graduated by $1964 .^{83}$ The proximity with the capital gave a number of these young Guatemalan officers the chance to forge close links with government officials, Congressmen and U.S. military officers at a number of professional and social functions. ${ }^{84}$

Another important component in U.S. sponsored Guatemalan counter-insurgency training was the U.S. Army Special Forces Mobile Training Teams (MTTs). These consisted typically of twelve to thirty-six men squads of Green Beret specialists who were flown in from the United States Eighth Special Forces Group at Fort Clayton in the Canal Zone to train Guatemalan non-commissioned officers in weapon use, equipment maintenance, paramilitary techniques, and anti-guerrilla operations. ${ }^{85}$ A great advantage of the MTT concept was that it allowed the Executive Branch in emergencies or otherwise to donate potentially vast amounts of specialized training, equipment, even manpower, to Guatemala off budget. MTT costs were outside the Military Assistance Program (MAP) funding for a particular country such as Guatemala. They were billed instead to the Eighth Special Forces and Southern 
Command's budget in Panama. Equipment could be "lent" from the Eighth Special Forces, training provided, even direct combat troops supplied without it ever showing up as an overrun on Guatemala's MAP budget. The MTT program allowed both the Kennedy and later Johnson Administration to circumvent Congressional oversight in their counter-insurgency war in Guatemala.

Willard F. Barber and C. Neale Ronning's 1966 Internal Security and Military Power in Latin America provides an excellent analysis of the Kennedy militarization of Latin America in the early 1960s. An orthodox or neo-conservative work and nowhere near as critical as later studies by Immerman, LaFeber, Stephen Schlesinger, or Rabe, Internal Security and Military Power was, nonetheless, ahead of its time in calling into question many assumptions of the Kennedy Doctrine. The authors proved prescient in their delineations of said doctrine's contradictions. Another excellent work in this vein is Cesar D. Sereseres' 1971 doctoral dissertation "Military Development and the U.S. Military Assistance Program for Latin America." Sereseres argues that Kennedy's program did succeed, but only in transmitting military expertise, not democratic values, to Guatemala.

All this vast panoply of inter-country training brought increased contact between United States and Guatemalan military personnel. Part of the whole assumption behind this effort (for Congressional sensibilities anyway) was that such contact had a beneficial effect on the social and political views of Guatemalan officers. Secretary of Defense Robert McNamara assured a Senate subcommittee that "the experience we have had indicates that exposure of military officers to our schools acquaints them with 
democratic philosophies and democratic ways of thinking which they in turn take back to their countries." ${ }^{186}$ How instructions on the proper method for slitting a guerrilla suspect's throat with a K-bar knife fit into this scenario, the Secretary never elaborated. Even within the Kennedy Administration, considerable skepticism existed on this point. In 1963, Assistant Secretary of State Edwin Martin stated:

Theoretically we can put vast amounts of arms and riot equipment into Latin American hands today to stamp out rebellion and shoot down the Communist leaders and their followers. But in whose hands would we put these arms? How can we be sure that the riot quellers of today will not be the rioters of tomorrow? What good are arms and security controls in a permanently unstable society? ${ }^{87}$

These words could serve as the epitaph for the Kennedy Doctrine in Guatemala.

Senator Edward Gruening, a sharp critic of Kennedy's Latin American policy, stated early in 1962 :

Latin American military leaders contrary to the Administration's misplaced faith in them, will continue to react to power struggles in their own countries in accordance with their own estimates of the situation, their own ambitions, their vested privileges, and their own heritage. Democracy does not rub off by commingling of individuals or by grants of military assistance. ${ }^{118}$

Since it would neither fundamentally change its investment and trade policy with Guatemala, nor use its political and economic leverage to force through real agrarian reform, the Kennedy Administration chose the military option together with some largely cosmetic local improvement projects (this is not to say that the people involved in these projects were insincere). It decided ultimately to bet on the Army and the internal security system of Guatemala in order to achieve its over-arching strategic goals. This militarization of policy was by no means unique to Guatemala. It took place within a continental, indeed global, context. When Premier Khrushchev said in 1961, "We will bury you," he fed into the fears of the Kennedy Administration that 
Third World nationalism, both in Latin America and among the newly emergent African and Asian nations, would naturally embrace World Communism and not the United States. While in retrospect much of Khrushev's rhetoric can be seen as bluff, at the time to many highly respected observers the communist movement seemed in ascendancy. As William O. Walker III has pointed out in his excellent 1994 article, "Mixing the Sweet with the Sour: Kennedy, Johnson, and Latin America," the 1962 Cuban Missile Crisis combined with the, frustration and failure of implementing reforms, pushed the Kennedy Administration irrevocably in its last year or so towards a less idealistic, more hard line stance in Latin America. The White House accepted military coups in Argentina, Peru and Bolivia without cut-offs of economic or military assistance, which it had formerly employed in such instances. ${ }^{89}$ As one diplomat brazenly put it, Latin American governments needed "less development and democracy, and more machine guns." ${ }^{\text {90 }}$ The table below showed how massive and unprecedented a buildup the Kennedy program embodied in the Western Hemisphere.

TABLE $X^{91}$

UNITED STATES MILITARY AID TO LATIN AMERICA $1952-1963$

Fiscal Year

1952

1953

1954

1955

1956

1957

1958

1959

1960

1961

1962

1963
Amount (in dollars)

$$
\begin{array}{r}
200,000 \\
11,200,000 \\
34,500,000 \\
31,800,000 \\
30,400,000 \\
43,900,000 \\
47,900,000 \\
54,600,000 \\
53,700,000 \\
91,600,000 \\
123,200,000 \\
\hline 149,700,000 \\
\hline
\end{array}
$$


While a gradual buildup already commenced under the Eisenhower Administration (the huge leap from 1953 to 1954 was at least partially attributed to the anxieties surrounding the 1954 Guatemalan coup), the virtually $300 \%$ increase from 1960 to 1963 remained striking. With the advent of the Kennedy Doctrine, the Cold War had truly come home to Guatemala and substantial other parts of Latin America.

The Kennedy Administration's creation of an almost parallel secret Counter-insurgency State stretched out both vertically and horizontally from the lofty heights of the White House to the Department of Defense, the Agency for International Development, the FBI, CIA, to the U.S. Embassy in Guatemala City, the National Palace, seat of the Guatemalan Government and Military, to Training Centers and Academies all over the world, and finally to individual nineteen year old Guatemalan officers and conscripts and Mayan couples and their impoverished children drinking dirty water from empty U.S. ration cans. The immense scope, bureaucracy and import of this effort testified to the enormous influence the United States imposed on Guatemalan society at every level in the early 1960s. The contrast was even more striking compared to the 1940 s and 1950 s when, as one State Department official, put it: "Except for an occasional flare-up, the Latin American Desk was always a good place to take a nap." ${ }^{12}$ By the early 1960 s, the Kennedy White House saw to it that no one was sleeping. The vast expanded machinery of statecraft kept grinding remorselessly well into the night with all its attendant consequences. The Cuban Missile Crisis had shown that the war for the soul of Latin America could indeed be a war to the death, involving vast global stakes. The outbreak of leftist insurgencies throughout 
the region, combined with the immense increase in U.S. military assistance, set the stage for over three decades of "dirty war" in the Western Hemisphere. That war would first commence in Guatemala. 


\section{CHAPTER III FOOTNOTES}

1 "The Speeches of John F. Kennedy, Presidential Campaign of 1960", (Washington, DC: GPO, 1961), p. 73.

${ }^{2}$ Thomas G. Paterson, ed., Kennedy's Quest for Victory: American Foreign Policy 1961-1963, (New York: Oxford University Press, 1988889), pp. 14-17.

${ }^{3}$ John F. Kennedy, Public Papers: 1961, Washington, DC: GPO, 196112), p. 172 .

${ }^{4}$ Ibid, pp. 175-6.

${ }^{5}$ Ronald Steel, Pax Americana, (New York: Viking Press, 1967), pp. 215-216.

${ }^{6}$ Paterson, Kennedy's Quest for Victory, p. 16.

${ }^{7}$ Richard M. Immermann, The CIA in Guatemala: The Foreign Policy of Intervention, (Austin: University of Texas Press, 1982), p. 24.

${ }^{8}$ John R. Hildebrand, "Latin American Economic Development, Land Reform and U.S. Aid with Special Reference to Guatemala," Journal of Inter-American Studies 4 (July, 1962), p. 357-362.

9 Ibid, p. 363.

${ }^{10}$ Severo Martinez Pelqez, La Patria del Criollo, (San Jose, Costa Rica: Editorial Universitania Centroamericana, 1979), pp. 355-360.

${ }^{11}$ Roger Burbeck and Patricia Flynn, Agribusiness in the Americas, (New York: Montbly Review Press, 1980), p. 214. 166.

${ }^{12}$ La Feber, Inevitable Revolutions: The United States in Central America, $p$.

${ }^{13}$ George Wythe, The United States and Inter-American Relations: A Contemporary Appraisal, (Gainesville: University of Florida Press, 1965), p. 81.

${ }^{14}$ Tom Berry and Deb Preusch, The Central American Fact Book, (New York: Grove Press, 1986), p. 28.

${ }^{15}$ David Tobis, "The Alliance for Progress: Development Program For the United States," Monthly Review (January, 1968) Vol. 39, pp. 94-97.

${ }^{16} \underline{\text { Ibid, }}$, p. 98. 
${ }^{17}$ Lucien W. Pye, "The Roots of Insurgency and the Commencements of Rebellions," in Internal War: Problems and Approaches, ed. Henry Eckstein, (New York: Face Press, 1964), pp. 157-180.

${ }^{18}$ Richard Adams, Crucifixion by Power: Essays on Guatemalan National Social Structure 1944-1966, (Austin: University of Texas Press, 1970), pp. 201-203; Stephen M. Streeter, "Reform or Revolution: The Alliance for Progress in Guatemala," (a paper presented at the Southwestern Social Science Association March 17-20, 1993 at New Orleans, Louisiana), pp. 5-6, cited with permission of the author.

${ }^{19}$ Jean-Francois Revel, When Democracies Perish (Garden City, NY:Doubleday, 1985), p. 13.

${ }^{20}$ Miguel Angel Albizurez, "The Oligarchy and the Kennedy Administration in Guatemala", Latin American Perspectives, (Spring and Summer 1972), Vol. 49, p. 63.

${ }^{21}$ Barry and Preuch, Central America Fact Book, p. 113.

${ }^{22}$ From a July 12, 1962 AID Memorandum entitled "Poverty in the Countryside," WNRC, RG 288 OPS Box 6, Folder: Guatemala, General.

${ }^{23}$ Stephen M. Streeter, "Reform or Revolution: The Alliance for Progress in Guatemala," p. 7.

${ }^{24}$ Tom Berry, Dollars and Dictators: A Guide to Central America, (New York: Grove Press, 1983), pp. 123-124.

${ }^{25}$ Eduardo Galeano, Guatemala: Pais Ocupado, (Mexico City: Neustro Tiempo, 1968), p. 40.

${ }^{26}$ Riguberta Menchu, "In Guatemala We Indians Have No Childhood," from Guatemala in Rebellion: A Documentary History, ed. by Jonathan Fried, (New York: Grove Press, 1983), p. 197.

${ }^{27}$ Melville, Guatemala: The Politics of Land Reform, p. 130.

${ }^{28}$ Bell to Rusk, State Department Telegram 163, June 12, 1961, John F. Kennedy Library (hereafter JFKL), Presidential Office Files (hereafter POF), Countries Files, Guatemala, Box 18, Folder 2.

${ }^{29}$ Hardin to Rusk, April 14, 1962, WNRC RG 288, Agency for International Development, Box 78, Folder: Guatemala 1962.

${ }^{30}$ El Imparcial, March27, 1962, p. 12.

${ }^{31} \underline{\text { Ibid, }}$ p. 13. 
${ }^{32}$ Monahan to Hardin, June 12, 1962, WNRC RG 288, AW Files, Box 78, Folder: Guatemala 1962.

${ }^{33}$ Mulvey to Rusk, Nov. 2, 1963, JFKL, NSF, Countries Box 118, Folder: Guatemala, July to Nov., 1963.

${ }^{34}$ Rostow to Mulvey, Nov. 14, 1963, JFKL, NSF, Countries Box 118, Folder: Guatemala, July to Nov., 1963.

${ }^{35}$ JFKL, NSF, Meetings and Memoranda, Box 332, Folder: Training for Friendly Police and Armed Forces in Counter-insurgency.

${ }^{36}$ Michael McClintock, Instruments of Statecraft U.S. Guerrilla Warfare, Counter-insurgency and Counter Terrorism 1940-1990, (New York: Pantheon Books, 1992), p. 161.

${ }^{37}$ Willard F. Barber and C. Neale Ronning, Internal Security and Military Power: Counter-insurgency and Civic Action in Latin America, (Columbus: Ohio State University Press, 1966), pp. 181-4.

${ }^{38}$ Eqbal Ahmed, "The Theories and Fallacies of Counter-insurgency," The Nation, August 2, 1971, p. 74.

${ }^{39}$ Lieutenant General Trudeau to Rostow, March 20, 1961, JFKL, NSF, Department of Defense Memoranda, Box 274, Folder: Latin American Regional Security, Jan. 1961 - June 1961.

40 "Speeches of John F. Kennedy - The White House Years 1961-1963," (Washington, DC: GPO 1964), p. 63.

${ }^{41}$ NSAM 88, Sept. 5, 1961, JFKL, NSF, Meetings and Memoranda, Box 331, Folder: Training for Latin American Armed Forces.

${ }^{42}$ Ibid, p. 1.

43"Problems of Guatemalan Police Training,", Dec. 30, 1959, WRNC, RG 286, OPS, Box 60, Folder: Guatemala, General.

${ }^{44}$ Barber and Ronning, Internal Security, p. 179.

45 "Guatemala Police Equipment," Oct. 16, 1963, WNRC, RG 286, OPS, Box 62, Folder: Guatemala City, Monthly Reports.

${ }^{46}$ U.S. Congress, Senate Committee on Appropriations, Foreign Assistance Appropriations, 1963, 88th Congress 2nd Session, 1963, pp. 72-3. 
47 "International Police Academy Policy Guidelines," Oct. 3, 1963, JFKL, NSF, Regional Security, Latin America, Box 215, Folder: Police Training, Jan. 1962 - Jan. 63, pp. 2-3.

${ }^{48}$ lbid, pp. 12-14.

${ }^{49} \underline{\text { Ibid, }}$, pp. 32-33.

${ }^{50}$ U.S. Agency for International Development, US AID Operations Report, (Washington, DC: GPO, 1973), p. 47.

${ }^{51} \underline{\text { Ibid, }}$, p. 48.

52 "Police Training in Guatemala," Sept. 2, 19963, WNRC, RG 286, OPS, Box 61, Folder: Guatemala, General.

53 "Anti-Guerrilla Operations,", Jan. 4, 1962, JFKL, NSF, Regional Security, Latin America, Box Box 215, Folder: Counter-insurgency Training, 1962.

${ }^{54}$ Michael T. Klare and Cynthia Arnson, Supplying Repression: U.S. Support for Authoritarian Regimes Abroad, (Washington, DC: Institute for Policy Studies, 1981), pp. 129-130.

${ }^{55}$ Ralph Dungan to the President, March 15, 1962, JFKL, Presidential Office Files (hereafter POF) Countries, Guatemala, Box 118, Folder 6.

${ }^{56}$ Barber and Ronning, Internal Security, p. 6.

57 "The Speeches of John F. Kennedy, The White House Years 1961-1963, (Washington, DC: GPO, 1964), p. 78.

${ }^{58}$ Senate Committee on Foreign Relations, Hearings, Foreign Assistance Act of 1962, 87th Contress, 2nd Session, (April 9, 1962), pp. 76-7.

${ }^{59} \underline{\text { Ibid, pp. 82-3. }}$

60 "Civic Action Budget for Guatemala," April 12, 1961, JFKL, POF, Country Files, Guatemala, Box 118, Folder 1.

61 "Civic Action Operational Guidelines," March 4, 1961, JFKL, NSF, Regional Security Latin America, Box 215, Folder: Civic Action Programs, 1961.

${ }^{62}$ Stephen M. Streeter, "Guatemala: Managing the Counter-Revolution 1954-1961, (PhD. diss., University of Connecticut, Storrs, 1994), p. 467.

63"Problems with Civic Action Program - Latin America," Oct. 28, 1963, Department of Defense Memorandum 2114, JFKL, NSF, DOD, JCS Meetings and 
Memoranda, Regional Security Latin America, Box 276, Folder: Civic Action, Latin America.

${ }^{64}$ Gerald McGetrick, Peace Corp. Volunteer in Guatemala 1963-1964, to the author, Aug. 27, 1994.

${ }^{65}$ Major F. Abundio Maldonado, "Accion Civica Del Egercito De Guatemala," (Guatemala City: Guatemalan Government Publications, 1962), JFKL, POF, Country Files, Guatemala, General, 1962, Box 118, Folder 4.

${ }^{66}$ Eduardo Galeano, Guatemala: Pais Ocupado, p. 79.

${ }^{67}$ El Imparcial, Aug. 12, 1962, p. 12.

${ }^{68}$ Adolfo Gilly, "The Guerrilla Movement in Guatemala," Monthly Review, Part 1, May 1965, p. 23.

${ }^{69}$ Michael McClintock, Instruments of Statecraft, p. 167.

${ }^{70} \underline{\text { Ibid, }}$ p. 167.

71 "Country Team Schedule and Guidelines," Bell to staff, March 14, 1962, JFKL, NSF, Country Files, Guatemala, Box 118, Guatemala Security, Folder 6.

${ }^{72}$ David Jinckling, OPS advisor, to the author George Black, Garrison Guatemala, (New York: Monthly Review Press, 1985), p. 137.

${ }^{73}$ Andre Ronquie, The Military and the State in Latin America, (Berkeley: University of California Press, 1987), p. 133.

74 "Need for Expansion of Training for Latin American Militaries," Kennedy to McNamara, Jan. 12, 1963, JFKL, NFC, DOD Meetings and Memoranda, Box 274, Folder: Military Training, Jan. 1963 - Nov. 1963.

${ }^{75}$ U.S. School of the Americas Policy Handbook," JFKL, NFC, Regional Security, Latin America, Box 215, Folder: Military and Police Training.

${ }^{76}$ Mc Clintock, Instruments of Statecraft, p. 173.

77 John Saxe-Fernandez. "The Central American Defense Council and Pax Americana" from Louis Horrowitz, ed. Latin American Radicalism. (New York: Random House, 1969), p. 83.

${ }^{78}$ Walter LaFeber, Inevitable Revolutions, p. 152.

79 Department of Defense Annual Report 1964, (Washington, DC: GPO), Vol LVII, (September 19, 1966), p. 1421. 
${ }^{80}$ Barber and Ronning, Internal Security, p. 148.

${ }^{81}$ Mario Prayeras, "Guatemala's Army and U.S. Policy," Monthly Review, Vol. 37, No. 10, (March), p. 18.

82 "Training Facilities for Latin American Militaries," Gilpatric to Kennedy, January 14, 1962, JFKL, NSF, Regional Security, Latin America, Box 215, Folder: Training Schools.

83 "Inter-American Defense College Proposal," January 12, 1962, JFKL, NSF, DOD, JCS, Box 276, Folder: Military Action for Latin America.

${ }^{84}$ Richard Adams, "The Guatemalan Military," Studies in Comparative International Development, 4, No. 5, (March, 1968), p. 103.

${ }^{85}$ McClintock, The American Connection, p. 79.

${ }^{86}$ Senate Committee on Foreign Relations Hearings, Hearings Foreign Assistance Act of 1962, 887th Congress, 2nd Session, (April 5-18, 1962), p. 76.

${ }^{87}$ Edward Martin, "Communist Subversion in the Western Hemisphere," Department of State Bulletin, 48, No. 1237, (March 11, 1963), p. 356.

${ }^{88}$ Barber and Ronning, Internal Security, p. 45.

${ }^{89}$ William O. Walker III. "Mixing the Sweet with the Sour: Kennedy, Johnson and Latin America" from Linda B. Kunz, ed., The Diplomacy of the Crucial Decade: American Foreign Relations During the 1960s, (New York: Columbia University Press, 1994), pp. 58-59.

${ }^{90}$ Richard Millet, The Central American Militaries, (New York: Holmes and Meier, 1986), p. 207.

${ }^{91}$ Figures listed by Senator Gruening in Senate Debate, August 21, 1963 Reported in Congressional Record, p. 14414. 164.

92 Ralph Harrison to the author John Prados, The Presidents' Secret Wars, p. 


\section{CHAPTER IV}

\section{U.S. RESPONSE TO INSURGENCY AND POLITICAL CRISIS IN GUATEMALA 1962-1965}

On the morning of February 6,1962, a force of about fifty Guatemalan guerrillas attacked and captured two army outposts, one in the town of Morales, the other in Bananera, the headquarters of the United Fruit Company's Atlantic Division. The guerrillas seized weapons and money from the military posts and robbed the United Fruit office of $\$ 18,000$. The leader of both groups was the former Lieutenant Marco Antonio Yon Sosa, one of the key participants in the November 131960 military revolt against Ydigoras. Along with his compatriot Luis Augusto Turcios Lima, Yon Sosa launched a guerrilla insurgency which unnerved the Kennedy and Johnson administrations, turned both rebels into popular heroes and touched off what amounted to a thirty-year civil war Guatemala. As a sign of the desperate, devil-may-care recklessness of the Guatemalan guerrilla movement, Yon Sosa commandeered a transit bus that same day making all the passengers (many of whom cheered him) get off along a dirt road. He then crashed through a military roadblock with the bus, shooting out all the windows in a wild fire fight from which he narrowly escaped with his life. It would prove the first in a series of hairsbreadth escapes which only further enhanced his legend and frustrated the Guatemalan military's attempt to capture him ${ }^{1}$

Yon Sosa and Turcios Lima were only twenty-two and nineteen respectively when they joined the November 1960 revolt. Graduates of the Polytechnic School, Guatemala's military academy, they had both received training in guerrilla warfare at United States Army facilities as did most young Guatemalan officers; Turcios Lima at 
the Ranger school at Fort Benning, Georgia and Yon Sosa at Fort Gulick in the Canal Zone. Turcios Lima in particular enjoyed his sojourn in the United States. "Sure I liked it. We had the officers' club, 15 ounce Texas steaks, good clothes, the best equipment. Plenty of money, too; every month I sent $\$ 150$ to my mother. What worries did I have?"12

Neither Yon Sosa nor Turcios Lima embraced a coherent political philosophy at the time of the revolt, aside from the hyper-nationalism prevalent among young Guatemalan officers. Neither communism, socialism nor any long term societal reforms interested most of the rebels. Their three principal demands included the resignation of Ydigoras, the cashiering of politically appointed senior officers and the transformation of numerous military bases into educational centers. Indeed, on the morning of November 14th, when some eight hundred peasants presented themselves to the rebels at the Zacapa base and asked for arms, the officers refused to issue them ${ }^{3} \mathrm{~A}$ correspondent for the Christian Science Monitor wrote from Guatemala City that December:

It was the very limited scope of the movement's political orientation that caused its military downfall; having a huge arsenal and a military zone under its command signified nothing, so long as the military leaders did not understand clearly why they were fighting and towards what goal they were moving. ${ }^{4}$

Faced with the prospect of execution or lengthy imprisonment if captured, the more daring rebel officers escaped into the countryside. Yon Sosa fled to Honduras, while Turcios Lima managed to cross the border into El Savador. Along the way they frequently sought refuge among peasants and it was through this experience that 
Turcios Lima and Yon Sosa began their political conversion to Communism. Cesar Montes, a later guerrilla leader, explained::

In Guatemala, as in Honduras and El Salvador all the peasants helped and protected the rebels, tried to influence them and win them over to their side. The peasants' motive was not only to offer them solidarity and sympathy but also to win allies and leaders in their struggle for land. The peasants had done this with many rebel leaders over and over again; they had been doing it for years, for centuries. Many of the rebels did not respond but the effort was not in vain; the influence was felt by some, although not immediately. Yon Sosa and Alejandro de Leon's companeros did not jump to conclusions but little by little the peasants won them over.

In the spring of 1961 Yon Sosa and Turcios Lima slipped back into Guatemala and made several secretive forays to the capital. There they held talks with leaders of Guatemalan political organizations. Of the "mainstream" political parties in Guatemala, the Revolutionary Party (PR) was the most leftist oriented and one would assume sympathetic to the rebels' cause. The PR had been the party of the progressive liberal presidents Juan Jose Arevalo and Jacobo Arbenz, that had dominated Guatemalan politics during the revolutionary period, the so-called "ten years of spring" between the 1944 revolution and the 1954 U.S. backed coup. ${ }^{6}$

At this stage of its development, however, the Revolutionary Party frowned upon direct involvement with the violence prone rebels. Repression under both Castillo Armas and Ydigoras had decimated its ranks, imprisoning, executing and forcing into exile its most militant members. While the party detested Ydigoras, it hoped to replace him constitutionally in the 1963 elections. Turcios Lima and Yon Sosa could not wait that long.

In April 1961 Fidel Castro defeated the American sponsored Bay of Pigs invasion. This David over Goliath victory against the great imperialist enemy enthralled 
communists, socialists, revolutionaries, and common people throughout Latin America. Yon Sosa and Turcios Lima were no exception. The victory also moved Cuba into a tighter alliance with the Soviet Union. In July 1961, the two young Guatemalan rebels began talks with the Partido Guatamelteco del Trabajo (PGT), The Guatemalan Communist Party. "They were different from the others," Turcios Lima later told an interviewer: "They really cared about the people." ${ }^{17}$ From the very first meeting according to Turcios Lima "a close collaboration began between the PGT and the military rebels. ${ }^{18}$ But still in these first few years the Communists did not dominate the rebels' fairly broad based supporters. Guerrilla leader Camilo Sanchez recalled that when he joined the rebels he discovered "not only Communists but also sincere revolutionaries, Catholics, socialists, anarchists and people whose only aspiration was to overthrow the regime in order to replace it with something more equitable." ${ }^{\prime 9}$

In the same month of July 1961, Ydigoras' government executed one of Turcios Lima's and Yon Sosa's closest military comrades -- Alejandro de Leon who had been captured by the chief of the Secret Police. This act precipitated a marked hardening in the resolve of the rebels to embark on a program of violent revolution rather than seek the political solution advocated by the Revolutionary Party. The rebel group called itself the Guerrilla Movement Alejandro de Leon - November Thirteen (MR-13) - a name that commemorated both their fallen comrade and the abortive revolt of 1960 . In their February 1962 opening statement, broadcast over a secret radio transmitter and printed on thousands of leaflets distributed throughout Guatemala City, the guerrillas declared:

Democracy vanished from our country long ago. No people can live in a country where there is no democracy. That is why the demand for 
change is mounting in our country. We can no longer carry on in this way. We must overthrow the Ydigoras government and set up a government which respects human rights, seeks ways and means to save our country from its hardships, and pursues a serious self-respecting foreign policy. ${ }^{10}$

This statement contained little in the way of Marxist ideology yet the Ydigoras government immediately branded MR-13 a Castro-Communist movement hiding behind a progressive mask "to better dupe naive supporters and lull the United States into complacency."11 Richard Gott's 1970 Guerrilla Movements in Latin America is one of the first revisionist studies of the guerrillas in Guatemala. It paints a complex portrait of the various guerrillas' motivations and ideologies. Though clearly leftist, even Marxist in orientation, the Guatemalan insurgency, according to Gott, was never Moscow or even Havana controlled. Still it would later derive considerable moral and ideological support form the world wide communist movement. Unlike Marxist writers, Eduardo Galeano and Adolfo Gilly, Gott correctly perceived no inevitability to the guerrillas' success and is frank about their relative weakness in the 1960 s.

Though their initial attacks were militarily insignificant, the guerrillas succeeded in electrifying the anti-Ydigoras forces within Guatemala and precipitated the first of numerous political crises. A further collapse in coffee prices and government losses in the December 1961 National Assembly Elections contributed to the social and political tensions. After leftist gunmen assassinated his universally despised Secret Police chief, Colonel Renulto Gonzalez, on January 24, 1962, Ydigoras declared a state of siege, shut down the University of San Carlos and flooded the capital with troops. ${ }^{12}$ When the guerrillas began their attacks a few days later, students, labor unions and rebel 
sympathizers organized large demonstrations and strikes throughout Guatemala. In the capital the demonstrations turned to riots. On February 16th student militants captured two radio stations in the capital and began broadcasting various Castroite and anti-Ydigoras tracts. ${ }^{13}$ In early March another guerrilla front, this one led by rebel Colonel Paz Tejada, called the "October 20th Front" in honor of Juan Jose Arevalo's 1944 revolution, began attacks on the government from Honduras. Sympathizers detonated bombs throughout the capital. ${ }^{14}$ Ydigoras called up 20,000 reservists and stationed scores of soldiers in U.S. provided armored vehicles on every street corner of Guatemala City. U.S. Ambassador John O. Bell feared the President was losing his grip. He wired the military authorities in Panama "to prepare for emergency measures. ${ }^{15}$ On the recommendation of the Commander in Chief Caribbean, the Joint Chiefs of Staff dispatched a carrier group to Guatemala and ordered six additional C-130 transport planes to reinforce already alerted paratroopers and Special Forces in the Canal Zone. ${ }^{16}$ Outraged Guatemalan political demonstrators continued to call for the President's resignation. These included not just the centrist Revolutionary Party (PR) and the Christian Democrats (CID) but even the right-wing National Liberation Movement (MLN) which held Ydigoras responsible for the revolutionary chaos and resented his recent extremely modest land reform and tax proposals. ${ }^{17}$

With both the right and left against him, all Ydigoras really had to turn to was the Guatemalan military and the United States. Fear of a second Cuba gripped both the State Department and the National Security Council which met on March 1st to discuss the crisis in Guatemala. The prospect of the Guatemalan government falling in a coup to leftist, possible Communist guerrillas and their political supporters, constituted the 
ultimate nightmare of the Kennedy Administration. Its entire doctrine had been designed to prevent this. Ydigoras played "the American card" masterfully. He wrote President Kennedy on February 28, 1962, advising him that "the Cubans will be here in a matter of days." 18

In April 1962, the Kennedy Administration took its first serious political step in Guatemala when it encouraged U.S. ambassador John O. Bell to broker a political agreement whereby the "Guatemalan military assumed virtual control of Ydigoras' government. Increasing U.S. support for praetorianism or de facto military rule within the Guatemalan government can be traced from this date. The Guatemalan military was so concerned over the unrest it probably would have taken this step in any case. But U.S. support steeled their determination. "I conveyed to the military chiefs the United States understanding of the need for drastic measures in such a crisis," John Bell wrote to Secretary of State Dean Rusk. ${ }^{19}$

Ydigoras replaced under pressure ten of his eleven civilian cabinet ministers with military officers, an unprecedented step in Guatemalan history. Only his civilian foreign minister, Unda Murillo, remained. ${ }^{20}$ The most powerful of these appointees was the Minister of Defense Colonel Enrique Peraita Azurdia, the Guatemalan officer with the strongest ties to the United States, who had most vigorously advocated the U.S. military doctrines of civic action, counter-insurgency, and out-of-country U.S. training for Guatemalan officers. Peralta had served as Chief of Delegation on the Inter-American Defense Board at Fort McNair, Washington, DC. He had also been chief military attache to the Guatemalan Embassy in Washington, 1957-1959. ${ }^{21}$ In a 
comparison with a similar scenario unfolding in South Vietnam at almost the same time, if Ydigoras represented the Diem of Guatemala, Peralta Azurdia was the Ky.

The bulk of the Guatemalan military remained estranged from Ydigoras despite his belated efforts since the November 1960 revolt to regain their favor. Ydigoras especially indulged his Air Force. Well aware that most Latin American coups began with the bombing of the Presidential Palace, he doubled Air Force salaries, issued smart, distinctive blue uniforms and allowed pilots to supplement their incomes by up to $\$ 20,000$ a year through crop dusting. His pampering of the Air Force widened the rift between the two services which had intensified due to the alacrity with which the Guatemalan Air Force bombed rebel Army officers during the November 1960 uprising. The Guatemalan Army long regarded the Air Force established during World War II by American advisers as a largely U.S. creation. ${ }^{22}$ Nicknamed the "old Fox", Ydigoras used these tactics of "divide and conquer" not only against his political rivals but against his own military, as did Diem, Ky, and Thieu in Vietnam. U.S. indoctrination and training of the Guatemalan military, combined with the general ideological demonization of Castro presented in all U.S. service schools, contributed to the combined messianic and siege mentality of the Army's leadership in the crucial February-April 1962 crisis. Leading officers felt they had to take command "to save their country from the clutches of diabolical Castro-Communism. ${ }^{.23}$ Aside from radio broadcasts of moral support, however, few credible links existed between Castro and the demonstrators.

The increased flow of U.S. military equipment, training and technology greatly enhanced the prestige of the Guatemalan military, boosting its power and influence at a 
time when other segments of Guatemalan society appeared weak and fragmented. With most of its reform elements either dead or radicalized, the military's nationalism became wedded with a sharp distrust of all left leaning social reform. In a similar situation in October 1944, the military responded to the popular will and overthrew the tyrannical regime of Jorge Ubico, ushering in ten years of democracy. In April 1962, the officers closed ranks around the unpopular Ydigoras and crushed the general strike.

Their appetite for, political power whetted, indeed sanctioned, by the United States, segments of the Guatemalan military next plotted the overthrow of Ydigoras himself to be replaced by a military junta. An interesting aspect of this process was the United States' constant denial of the effects of its own collaboration with the military at virtually every step of the way. In a telegram to the State Department dated August 14, 1962, Ambassador John O. Bell stated:

I believe close U.S.-Latin military association does contribute something to the development of Latin American military respect for democratic and progressive policies and a great deal to their understanding of the dangers of communism. I do not suppose this or any other association likely to persuade the military of the desirability of adhering to "Constitutional principles" if such adherence appears to them the equivalent of delivering themselves and their country into hands of radical regimes apt to produce Castro-type government... While there may be some truth to the notion that U.S. equipment used increase military prestige and increases the capability to suppress the citizenry whether such increased capability will or will not be used to suppress democracy or democratic elements is determined by attitudes and not the possession of non-possession of U.S. equipment..Recent MAP policies accentuating internal security mission and encouraging civic action seem right to me... ${ }^{24}$

After his second close call in February-April 1962, Ydigoras still displayed amazing political survival skills. Realizing that once he crushed the small rural insurgency in Guatemala, his usefulness to the United States might end, he cleverly dithered on the anti-guerrilla front to the disgust of both the Guatemalan military and 
the U.S. embassy's Military Assistance Advisory Group (MAAG) ${ }^{25}$ In late October 1962 , once again playing the reformer, he even enacted the country's first income tax. ${ }^{26}$ This proved too much even for his favorites in the Air Force. On November 25, 1962, encouraged by members of the oligarchy and upset over the possible retum of the liberal former president Arevalo, a number of pilots bombed the National Palace. Ydigoras emerged, covered with plaster and according to his own questionable account (he was sixty-six at the time), began firing at the jets with a machine gun from the roof of his palace. ${ }^{27}$ Again Ydigoras' byzantine intra-service tactics paid dividends. The Army, long jealous and resentful of its sister service's numerous perks, enthusiastically put down the revolt. Several senior Army officers, Colonel Peralta among them, feared a leftist takeover if the President was suddenly and violently overthrown. They planned on getting rid of him much more gradually themselves. ${ }^{28}$ James Dunkerly's 1988 post-revisionist work, Power in the Isthmus, supplies a detailed view of Guatemala's internal politics throughout this period. Unlike earlier revisionists, such as LaFeber, Immerman, Stephen Kinzer and Stephen Schlesinger, who tend to attribute almost all of Guatemala's problems to outside manipulation, Dunkerly explores the inner workings of Guatemalan domestic politics, the influences of both Spanish and Indian culture, and the complexities of class, race and ideology as they relate to Guatemalan society. While he views U.S. influence as a predominant constant, Dunkerly convincingly demonstrates that Guatemalan politics provide the crucial catalyst for virtually all U.S. interventions.

The proposed return of former liberal progressive president Juan Jose Arevalo from exile in Mexico to run in the 1963 presidential election, lent additional urgency to 
the military's plans to oust Ydigoras. Ydigoras seemingly went along with Arevalo's political comeback, announced by the exiled president on Mexican radio. The "Old Fox" apparently wished to play the various political parties in Guatemala off against one another by maintaining the "Arevalo option." Speaking to rightist, Ydigoras condemned Arevalo; when addressing leftists he praised his reforms. Yet he took no definitive stand one way or the another to either ban the ex-president or let him run. The Guatemalan military took an extremely dim view of Arevalo. In the highly charged reactionary atmosphere of the Cuban Missile Crisis and an ongoing insurgency, it regarded even a largely centrist figure like the ex-president as a "dangerous crypto-Communist." ${ }^{29}$ Arevalo made his own contribution to the historiography of U.S.-Guatemalan relations with his early 1963 "dependency school" work, The Shark and the Sardines. Along with its title, Arevalo's overall viewpoint can best be encapsulated in a rough translation of one of his book's chapters: "The Pentagon, Wall Street, and the State Department -- Three Words for the Same Thing." His understandably bitter anti-American analysis equated U.S. policy with outright imperialism. He would soon face one wing of his designated unholy trinity.

The U.S. Embassy in a secret memorandum to the State Department, dated November 12, 1962, ominously entitled "The Possibility of a Preventative Coup," noted that the Military are determined to prevent the ascension of Arevalo to the presidency...No one should predict Ydigoras' early downfall...[but] the introduction of the fear of Arevalo adds an additional element of danger to the equation. Recent steps on Ydigoras' part to demonstrate that despite his many contacts with Arevalo, he is really anti-Arevalo, probably were calculated to ease military minds." ${ }^{30}$ 
Student and labor groups stepped up their demonstrations throughout the winter of 1962-1963 as the Guatemalan left anticipated the return of their hero, Arevalo, the father of the 1944 revolution. Yon Sosa, Turcios Lima and Colonel Paz Tejada increased their hit and run guerrilla attacks in the Sierra de las Minas mountains, frequently cutting commercial traffic along the main Atlantic Highway. All the guerrilla opposition movements in Guatemala united in December 1962 into the Fuerzes Armedes Rebeldes (FAR), Rebel Armed Forces. ${ }^{31}$ Ydigoras further piqued the U.S. military mission at this juncture by forbidding the creation of a heavy armored battalion for continental defense. ${ }^{32}$ He feared it would be used against him and his instincts proved prescient. The United States acquiesced and perhaps even conspired with Ydigoras' defense minister Colonel Peralta Azurdia in the March 1963 plot to overthrow the president.

Ambassador John O. Bell met with Ydigoras for the last time on March 25, 1963. In a telegram summarizing their meeting, Bell stated:

I told him in my view neither Guatemala nor the United States could accept the control of the government of Guatemala getting into hands which would be likely to deliver the country to communism again...Certainly if it were possible to defeat Arevalo in a honest and clean election that would be a ideal. However there was a great danger that Arevalo might win the election either because the issues weren't clear, the opposition was too divided or the people might be deceived as to his character. ${ }^{33}$

Bell went on to say that Ydigoras' position on "alternatives to the elections were guarded and unclear." Worse, Bell mentioned Ydigoras' saying that "Arevalo according to the Constitution had a legal right to enter the election." A follow-up CIA report accused Ydigoras of "collusion with the Marxist orientated Arevalo."134 
Five days previously Ydigoras had met with President Kennedy at the Central American Presidents Meeting in San Jose, Costa Rica. Kennedy, according to Ydigoras, was noticeably "chilly" towards him. CIA reports of the period persistently questioned Ydigoras' "reliability" -- notoriously dangerous words in the intelligence community. ${ }^{35}$ On March 27, Arevalo arrived secretly in Guatemala City, setting off huge political rallies and numerous, according to the Office of Public Safety accounts -"anti-American disturbances." ${ }^{136}$ This new crisis took place at a time when the United States was obsessed with the deterioration of another of its authoritarian allies -- the Diem regime in South Vietnam.

A constant shuttle of Guatemalan high ranking military officers to and from the U.S. Embassy followed until on the morning of March 31st, Ydigoras awoke to a Sherman tank crashing through his residence's front gate. Defense Minister Peralta Azurdia announced a suspension of the 1956 Constitution, declared a state of siege and then almost as an afterthought proclaimed himself "Chief of State. ${ }^{137}$

An absolute "smoking gun" of U.S. complicity in the coup has yet to be declassified. "Citing top sources within the Kennedy Administration" journalist Georgia Anne Geyer in a December 24, 1966, article in the Miami Herald disclosed that President Kennedy chaired a secret meeting in early January, 1963, which "gave the green light" for a coup against Ydigoras. ${ }^{38}$ Two of the five alleged participants denied the meeting took place. One, Assistant Secretary for Inter-American Affairs, Edwin Martin, insisted the United States never approved an overthrow. "No initiative was required for the military to oust Ydigoras," he told interviewers. He later admitted: "We decided not to try to stop the military if they moved to overthrow Ydigoras, a 
quite different thing from initiating a coup. ${ }^{139}$ Stephen Schlesinger and Stephen Kinzer in their 1983 Bitter Fruit provide one of the better accounts of U.S. machinations in the 1963 coup though they slight Guatemalan participation. The whole 1963 episode remained strikingly similar to the November 1963 Diem coup in South Vietnam. In both cases evidence from the conspirators supports the notion that at the very least the United States could have stopped either coup if it so desired. The military plotters in both cases would not have dared to act without the expressed sanction of the United States. Ydigoras fared better than the assassinated Diem. The military exiled him to Nicaragua, where he sulked and wrote his memoirs.

In an April 3, 1963, news conference, a reporter asked President Kennedy in direct reference to the coup: "Are we going to have any consistent or uniform policy on whether or not to recognize governments that take power by force?" Kennedy replied: "No, we haven't got a consistent policy because circumstances are sometimes inconsistent... This government that has taken over in Guatemala has indicated that it will eventually provide a return to civilian rule..." ${ }^{40}$ In reality "civilian rule" would not return for three more years. On April 17, 1963 the United States recognized the new "government" a mere 18 days after the coup. In fact, by this time the Kennedy Administration did have a consistent policy on military coups in Latin America: if the officers involved expressed a strict anti-communist line, their government would be recognized; if the officers endorsed a leftist program, as in the 1963 military revolt in Bolivia, the United States withheld recognition and cut all aid. By 1963 the White House regarded the promotion of democracy in Latin America, so prevalent in its 1961 
rhetoric, as impracticable given the exigencies of the Cold War. The Johnson Administration's Mann Doctrine of 1964 would crystallize this transformation.

Ironically Colonel Peralta Azurdias' military government which the Kennedy Administration hoped would immediately attack the guerrillas hesitated to unleash an all out counter-insurgency war. The reasons proved complex. First, Peralta may have genuinely desired a rapprochement with the guerrillas. Though he had not taken part in the 1960 revolt, Peralta had a reputation as a mentor and confidant of many of the younger rebel officers. He regarded a number of them as misguided youths who might yet be brought back into the fold now that their arch-nemesis, Ydigoras, had been usurped. Military solidarity and fraternity were intense throughout the Guatemalan Armed Forces and in the early phases of the insurgency, many officers hesitated to fire upon brother officers, a phenomena which also occurred in the early months of the American Civil War. Second, Peralta, by all accounts a consummate professional, didn't feel his military was ready yet to take on a large-scale counter-insurgency campaign whose failure might cast a negative reflection on him. Third, like Ydigoras, Peralta recognized the advantages to having a troublesome if not especially virulent guerrilla movement in Guatemala. It guaranteed continuous large scale U.S. economic and military aid and tended to portray him as a heroic, emabattled free world leader. Peralta was also something of a nationalist who didn't like being ordered about constantly by the United States Military Mission. ${ }^{41}$ The notion that all Latin American military leaders were hopeless dupes of the United States is far too simplistic a characterization. Despite its strong alliance with Washington, the Guatemalan military possessed a fierce 
nationalist tradition which often complicated its relationship with the United States. The U.S. in turn grew increasingly frustrated with the new junta.

Peralta in any event proved a much more serious commander-in-chief than Ydigoras. He cracked down on corruption and brought in a new breed of efficient, largely military administrators, engineers and specialists establishing a sort of "military technocracy." In May, 1962, in his capacity as Defense Minister, Peralta had already authorized the construction of a secret counter-insurgency base in Maricos, Izabal, in the heart of guerrilla country. Members of a U.S. Special Forces Mobile Training Team (MTT), consisting of three officers and three enlisted men, supervised anti-guerrilla training at the base. All were Vietnam veterans and of Puerto Rican or Mexican descent, chosen for their language skills and presumably to keep the operation less conspicuous. Fifteen hand-picked Guatemalan officers, trained in counter-insurgency at the U.S. Army School of the Americas, augmented the American staff. This base constituted the first counter-insurgency training facility outside United States territory in the Western Hemisphere. ${ }^{42}$ It became a model for dozens of others, installed in Peru, Colombia, Bolivia, Honduras, Chile, Ecuador and Argentina in the 1960s and 1970s during the Johnson and Nixon Administrations. The base provided the embryonic seed for the larger Guatemalan Army's counter-insurgency battalions which would wreck such havoc in the countryside in the mid-1960s.

In the fall of 1962 , Peralta tested some of the smaller units trained at this specialized facility. Transported by helicopter, led by Green Berets and reinforced with U.S. paratroopers, they effectively wiped out Colonel Paz Tejada's "October 20th Front". Pleased with these results, Peralta agreed to an expansion of the program In 
the years of the military government, 1963-1966, Peralta with the principal aid of the United States instituted a large specialized military build-up and modernization program for all of Guatemala's armed forces. ${ }^{43}$

In January 1963, the U.S. Congress approved the FY 1963 U.S. Military Assistance Program (MAP) for Guatemala budgeted at $\$ 1,667,000$. This was revised upwards after the March 31, 1963 coup to a total of $\$ 2,524,000$. (The 1960 allocation, Eisenhower's last, was $\$ 313,000$.) The U.S. further boosted assistance by "windfall funds", monies provided under an AID "Civic Action" budget, raising the total dollar value of the package $\$ 325,000$ to $\$ 2,849,000 .^{44}$ The Department of Defense disbursed additional grants to this amount in the fall. Overall this constituted a roughly $900 \%$ increase over the FY 1960 allocation. AID's Office of Public Safety's Guatemalan budget for 1963 was $\$ 382,000$, a $550 \%$ increase over the $\$ 71,000$ spent in 1962 . (There had been a considerable drop in funding from $\$ 271,000$ in FY 1961 to $\$ 71,000$ in FY 1962, attributed both to overgenerous investments the previous two years and U.S. disenchantment with Ydigoras after the February-April 1962 uprising which the Guatemalan military, not the OPS funded police, put down.) The United States made another huge totally unrecorded contribution to the Guatemalan military in this period. The CIA donated some $\$ 5$ million in military hardware (planes, landing craft, mortars, bombs, ammunitions, and small arms) left over in Guatemala from its failed 1961 Bay of Pigs Invasion. Rather than crate and cart the equipment back to the United States, the CIA simply gave it to its faithful collaborator, Ydigoras. The crafty president apparently warehoused much of it, fearful of his own military and planning to dole it out judiciously to individual officers for political favors. After the March 1963 coup, 
Peralta distributed all of this considerable cache to his Army, Navy and Air Force, further engorging them with weaponry. ${ }^{45}$

Total funding for the United States' military assistance to Guatemala dropped briefly in the years 1964 to 1966 before rising again in 1967 at the height of the counter-insurgency war. But 1963 was a peak year of heavy U.S. investment. (See table below.)

TABLE XI ${ }^{46}$

MILITARY AID TO GUATEMALA: 1962 - 1969

(Millions of dollars)

$\begin{array}{lcccccccr} & 1962 & \underline{1963} & \underline{1964} & \underline{1965} & \underline{1966} & \underline{1967} & \underline{1968} & \underline{1969} \\ \text { TOTAL MAP } & 2.072 & 2.35 & 2.063 & 1.339 & 1.489 & 2.247 & 1.225 & 1.993 \\ \text { Material } & 1.402 & 1.675 & 1.414 & .667 & 1.044 & 1.710 & .779 & 1.649 \\ \text { Training } & .49 & .475 & .520 & .528 & .305 & .436 & .336 & .244 \\ \text { Supply } & .180 & .205 & .129 & .800 & .100 & .400 & .260 & .050 \\ \begin{array}{l}\text { (US logistical aid) } \\ \text { Excess Grants }\end{array} & .600 & 1.100 & .200 & .800 & .100 & .400 & .200 & .050 \\ \text { Military Sales } & .106 & .027 & .276 & .448 & .600 & .334 & .210 & .590 \\ \text { TOT AL } & & & & & & & & \\ \text { MILITARY AID } & 2.666 & \underline{3.482} & 2.539 & 2.587 & 2.189 & 2.981 & 1.635 & 2.583\end{array}$

Army and Air Force equipment and ammunition levels attained new heights as well. The Air Force acquired 4 T-33 jet trainers and 4 C- 47 aircraft, both particularly suited for counter-insurgency operations. The Army received its first $4 \mathrm{U} \mathrm{H}-2$ 
helicopter gunships, as well as trucks, radios, walkie-talkies and small arms. By the end of 1965, five elite Guatemalan infantry battalions designated interestingly enough "MAP units" reached full strength under the Peralta Administration. They were equipped with the latest U.S. weaponry including .45 caliber pistols, .30 and .50 caliber machine guns, 60 and $81 \mathrm{~mm}$ mortars, M-16s, recoilless rifles, infrared night vision scopes, smoke and explosive grenades, even guerrilla sniffing German shepherds. ${ }^{47}$

Critics of the theory that U.S. military aid has a strong influence on the doctrine, capabilities and political predilections of Latin American militaries, such as Cesar D. Sereseres, point out that U.S. military aid is usually a relatively small percentage of the overall Latin American defense budget. And this is certainly true in the case of Guatemala. As the chart on the next page shows in the year in question, 1963, when the United States funded the Guatemalan military with approximately $\$ 3.5$ million in military aid, the government of Guatemala itself spent $\$ 9.9$ million on its own defense budget. 
TABLE XII ${ }^{48}$

\section{GUATEMALAN DEFENSE APPROPRIATIONS \\ (in millions of dollars)}

\begin{tabular}{|c|c|c|c|c|}
\hline Presidential Office & $\underline{1961}$ & $\underline{1962}$ & $\underline{1963}$ & $\underline{1964}$ \\
\hline General Staff of the President & .842 & .798 & .674 & .608 \\
\hline Presidential Guard & .247 & .282 & .259 & .279 \\
\hline \multicolumn{5}{|l|}{ Ministry of Foreign Relations } \\
\hline \multicolumn{5}{|l|}{ Central American Defense Affairs } \\
\hline Ministry of National Defense & 8.804 & 9.124 & 8.988 & 10.994 \\
\hline Personnel Services & 5.170 & 5.167 & 5.285 & 6.026 \\
\hline Salaries for Officers & 1.965 & 1.965 & & \\
\hline Salaries for Specialists & 1.800 & 1.740 & 4.504 & 5.196 \\
\hline Salaries for Enlisted & .840 & .863 & & \\
\hline Commissions and Pensions & .565 & .641 & .781 & .830 \\
\hline Regular Operations & 3.504 & 3.778 & 3.653 & 4.968 \\
\hline $\begin{array}{l}\text { General Services-Food, } \\
\text { Medicine, Fuel, etc. }\end{array}$ & 3.285 & 3.560 & 3.434 & 4.750 \\
\hline $\begin{array}{l}\text { Maintaining Students and } \\
\text { Attaches Abroad }\end{array}$ & .168 & .168 & .168 & .150 \\
\hline Military Life Insurance & .050 & .050 & .050 & .050 \\
\hline \multicolumn{5}{|l|}{ Center for Development of Public } \\
\hline Administration & .001 & .001 & .001 & .001 \\
\hline \multicolumn{5}{|l|}{ Maintaining Students at Escuela de } \\
\hline Applicacion & -- & -- & -- & -- \\
\hline Investment and Construction & .130 & .178 & .050 & -- \\
\hline Construction/Navy Headquarters & .130 & .130 & -- & -- \\
\hline Construction/National Monumen & it $\quad--$ & .010 & -- & -- \\
\hline Acquisition of Vehicles & -- & .038 & -- & -- \\
\hline \multicolumn{5}{|l|}{ TOTAL FUNDS APPROPRIATED } \\
\hline FOR ARMED FORCES & 9.893 & 10.204 & 9.921 & 11.88 \\
\hline
\end{tabular}

But as the above Guatemalan Defense Appropriations chart demonstrates, the vast majority of the nation's own defense funding went to salaries, maintenance of facilities and equipment, food, fuel, pensions, health care, insurance, and the like. 
Thus, while the U.S. proportion of the $\$ 13.4$ million spent on defense in Guatemala in 1963 (Guatemala's $\$ 9.9$ million plus the U.S.'s $\$ 3.5$ million) was only $26 \%$, it provided the crucial $26 \%$ comprising all the new equipment and specialized training for elite counter-insurgency units, the so-called "tip of the spear" of the Guatemalan Army. This $\$ 3.5$ million imposed United States military doctrine on the Guatemalan Armed Forces with its emphasis on counter-insurgency and civic action.

The bulk of Guatemala's roughly 10,000 man Army were largely defensive, maintenance, and administrative troops. The "MAP units", on the other hand, made up an elite anti-guerrilla strike force. They consisted of five battalions. The Army based three of them in Guatemala City: the two principal infantry battalions, Brigada Mariscal

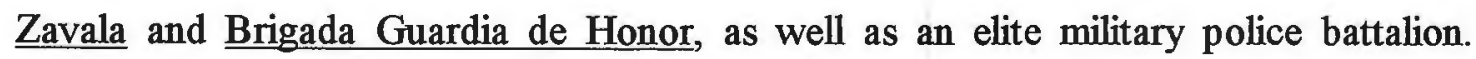
These were crucial because U.S. military advisors hammered home the importance of maintaining absolute control in the capital city. Similar to Saigon in South Vietnam, Guatemala City was the nerve center of the U.S. Military Assistance Advisory Group (MAAG), the U.S. Embassy, the seat of the Guatemalan government and military command, the vital political, economic and communication center of the nation. As in Vietnam, U.S. and allied forces could afford to give up considerable portions of the countryside, but always had to be able to hold the capital and put down any popular insurrection or internal coup there "with first rate politically reliable troops. ${ }^{\text {"49 }}$

In the key rural guerrilla areas, the Guatemalan military stationed their remaining two elite battalions, the Brigada General Manuel Lisandro Barrillos in Quetzatenengo and the Brigada Capitan General Rafael Carrera at Zacapa. These battalions were not numbered as were all others in the Guatemalan Army, but rather 
were named after former Guatemalan nationalist and military heroes, signifying their elite status. In addition to these larger anti-guerrilla battalions, the United States helped develop several smaller specialist units for counter-insurgency warfare. These included the 1st Airborne Infantry Company, made up of elite paratroops modeled on the U.S. Army "Rangers"; the 1st Special Forces Company called "Kaibiles" (Ixal for Tigers) based on the U.S. Army "Green Berets"; a counter-insurgency unit menacingly referred to as "the CT Detachment" - "CT" teams in Vietnam during this period meant "Counter-Terror", and a "CI", Counter-Intelligence Detachment. Overall, these specialty units included about 800 airborne and airmobile troops in the Special Forces and Airborne infantry units, comprising the counter-insurgency shock troops of the Guatemalan Army. U.S. Vietnam veteran Green Beret advisors trained, groomed, and often hand-picked, each of these 800 "Tigers". ${ }^{50}$

On United States advice, the Guatemalan military emphasized the para-military side of the counter-insurgency equation as well. In 1963, Chief-of-State Peralta began a massive revamping and expansion of the comissionados militares or military commissioner system. These had formerly consisted of part time, unpaid, regional positions given typically to retired military or police personnel. Military commissioners could not bear arms, had to live in the district in which they served and were often appointed or even employed by local land-owners. They registered and called up military conscripts in their areas and reported on any local problems (i.e. political dissidence) to the Army. In 1963 they numbered 300. By 1966 there were 9,000 of them, armed and paid members of the military reserve, writing comprehensive monthly reports to the Army on subversion in their districts. They conducted surveillance of 
suspected enemies of the state, drew up lists of "peasant cooperative leaders, Indian union leaders, guerrilla sympathizers and leftist malcontents". ${ }^{51}$ The military commissioners became the eyes and ears of the Guatemalan Army deep in the countryside where the military seldom penetrated. Their force structure was actually even larger than the 9,000 men paid. Each commissioner normally had an informal group of supporters consisting of landowners and their sons, plantation foremen and overseers, businessmen, even local cantina toughs and hoodlums who could be counted on to join him in any vigilante action. ${ }^{52}$ Similar to the Civil Guard and Phoenix programs in Vietnam, the military commissioner system provided the Guatemalan military with a low cost, easy maintenance right wing hit squad in virtually every village in the country. Richard N. Adams in his 1970 Crucifixion by Power and numerous Latin American historians, particularly Alejandro de Coro in his suberb "Los commissionados militares en Guatemala, 1963-1966," emphasize the significance of this commissioner system in muzzling all political dissent in the countryside during the Peralta regime and afterwards.

Peralta also fit his new security apparatus into the larger regional context. Here the United States applied pressure though Peralta, who had served as his nation's delegate on the Inter-American Defense Board (IDB) appeared genuinely enthusiastic. On December 14, 1963, representatives of five Central American nations - Guatemala, Honduras, El Salvador, Nicaragua and Panama signed a treaty in Guatemala City creating the organization acronymed CONDECA (Consejo de Defensa Centroamericana) -- the Central American Defense Board. In a speech at the elaborate signing ceremony, Peralta said: 
A plan for the Defense of the Continent has been drawn up, presenting as the single and exclusive enemy -- Russia. The Central American Isthmus in this Plan...is considered as a unit not as five or six separate units. As a consequence what is required is a military organ formed of representatives of all the Armies of the Isthmus... ${ }^{33}$

Peralta's designation of Russia as the principal enemy of CONDECA was patently ludicrous and largely a political cover story. With the preponderance of American air, naval and amphibious power in the Caribbean, the idea of the Soviet Union, or for that matter Cuba, attempting an invasion of Central America defied credulity. Clearly the United States and Central American militaries created CONDECA as a larger more efficient instrument for coordinating internal security. Guerrillas in this period frequently displayed the annoying habit of crossing borders for sanctuary. Despite its attempts to publicize itself as a sort of NATO or SEATO for Central America, the organization was simply a larger regional counter-insurgency mechanism as U.S. Department of Defense documents confirm. CONDECA called for "a greater coordination of military and police operations against Communism" and "an interchange of information and intelligence as a contribution to the fight against regional subversion." ${ }^{54}$ In the first official meeting of CONDECA, held again in Guatemala City in 1964 , Peralta, who had come to power in a military coup, praised its potential as "a rampart for the protection of the democratic system." ${ }^{155}$ While a supposedly "independent security arrangement" CONDECA proved about as independent as the Organization of American States. Though not an official member, the United States through military aid, training and administrative command and control, effectively dominated the organization. 
Also in 1964, as part of this larger regional military integration, Guatemala joined the new U.S. constructed CAPTSN System, Central America and Panama Telecommunication Network which linked all the Central American military and police communications to the United States Southern Command in Quarry Heights, the Canal Zone. $^{56}$ Public Safety Communications Advisor, Alfred Nauracki, an old communications hand from Vietnam, helped construct this system within months of his arrival in Guatemala in August, 1964. In a Public Safety Report dated October 13, 1966, the system is described as:

A totally secure radio-teletype network which interconnects on a private frequency the principal officials of the Guatemalan National Police, Treasury Police, Judicial Police, Detective Corps, Ministry of Defense, the Presidential House and the Guatemalan Military Communications and Command Center with all analogous headquarters in the other four CONDECA nations as well as the United States Southern Command. ${ }^{57}$

Guatemala was now a full member of the Central American Counter-insurgency

Internet. Along with the United States, it had in fact created the network. In his 1985 work, The American Connection: State Terror and Popular Resistance in Guatemala, Amnesty International activist, Michael McClintock, painstakingly reconstructs the United States military and security assistance to Guatemala in the mid-fifties to early 1980s. It is McClintock's contention, which dovetails with Latin American military specialists, Edwin Lieuwen and Morris Janowitz's opinions that the exportation of the Kennedy counter-insurgency doctrine, equipment and training played a vital role in the creation of a number of brutal military governments which sprang to power in the region in the 1960s. In 1961 only one strictly military government held office in Latin America, that of Paraguay. By 1964 there were nine, Guatemala foremost among them. 
In the crisis years of 1962 and 1963, the unstable yet elected government of Miguel Ydigoras Fuentes staggered through innumerable political crises before it ultimately collapsed to a military coup. How legitimate the Ydigoras government ever was is clearly open to question. The March 1958 election that brought Ydigoras to power has alternatively been described as "a massive hypocritical fraud" and "one of the fairer elections in Guatemalan history. ${ }^{158}$ When analyzing a Guatemalan election in the 1950 s, it is important to remember that about half the electorate (illiterate Indians) could not legally vote and the $20 \%$ of Indians who could were usually too frightened of authorities to go near the polls. Therefore, if Ydigoras was a legitimate president, he was so only in the sense that say John Stennis of Mississippi was a legitimate senator in the 1950s. That having been said, Ydigoras' regime, however corrupt and repressive, was the constitutional government of Guatemala when military officers at the instigation, or at the very least, with the approval of the United States, overthrew it. The United States sponsored military build-up in Guatemala had been proceeding apace before the assumption of power by a military government, but it clearly took off on a substantially higher, more specialized trajectory afterwards. The United States put very little pressure on the Peralta regime in the years 1963-1965 to hold elections and, in fact, appeared much more at ease with his military caretaker government than with the volatile Ydigoras. Peralta did bring a measure of stability to Guatemala from 1963 to 1966 , but at a considerable price. Internal repression soared and the military grew in power to a proportion far exceeding its traditional role in Guatemala society. The U.S. obsession with the rather small 300 man Guatemala guerrilla movement led to a monstrous example of military overkill and to the acceptance of a government that 
violated all the ideals of the Alliance for Progress. This shift in Washington's policy was most fully embodied in the Johnson Administration's Mann Doctrine which will be analyzed in the next chapter. Ultimately, the United States sacrificed its hopes for economic and political reform in Guatemala like some ancient Mayan captive on the altar of counter-insurgency. Few State Department US AID, USIA, MAAG, or CINCSO documents questioned the absurdity of the United States spending an annual average of $\$ 583$ per Guatemalan soldier in a country where per capita income was $\$ 181$ (see table below).

Table XIII ${ }^{59}$

U.S. Military Assistance to Central America

Cumulative U.S. Military Aid, U.S. Military Aid per Member of $1952-1962$ Armed Forces 1962

Country (Millions of dollars) (dollars)

Nicaragua

3.813 930

El Salvador

1.136 169

Honduras

2.324

529

Guatemala

Panama

5.311

583

Costa Rica

.929

n.a.

.832

n.a.

But as Communist guerrilla leader Caesar Montes said, "As long as there was one rebel left bloody and ragged still fighting in the jungle, no landowner, no Yankee, no generalissimo could ever sleep in peace. ${ }^{160}$ All three of these distinct interests would unite for different reasons in the final phase of the Guatemalan counter-insurgency war of the 1960 s. 


\section{CHAPTER IV FOOTNOTES}

1 Richard Gott, Guerrilla Movements in Latin America, (London: Thomas Nelson, 1970), p. 65; Miguel Ydigoras Fuentes, My War With Communism, (Englewood Cliffs, NJ: Prentice-Hall Inc., 1963), pp. 185-187.

2 Quoted to Alan Howard, "With the Guerrillas in Guatemala," New York Times Magazine, June 26, 1966, p. 18.

3 Adolfo Gilly, "The Guerrilla Movement in Guatemala", Monthly Review, May 1965, p. 18.

4 Christian Science Monitor, Dec. 2, 1960, p. 2.

5 Manta Harnecker, Pueblos en Armas, (Manegua: Nueva Nicaragua, 1983), p. 24.

6 James Dunkerly, Power in the Isthmus: A Political History of Modern Central America, (London: Verso Book, 1988), p. 427.

7 Turcios Lima to Alan Howard, "With the Guerrillas in Guatemala," p. 19.

8 Camila Castano, "Avec les Guerrilles de Guatemala," Partisans, No. 38, (July-Sept. 1967), p. 150.

9 Ibid, p. 151.

${ }^{10}$ El Imparcial, February 10, 1962, pp. 1, 12.

1 Ydigoras, My War with Communism, p. 200.

12 "Report on State of Siege," Jan. 26, 1962, WNRC, RG 286, OPS, Box 60, File: Guatemala, General.

${ }_{13}$ New York Times, March 10, 1962, p. 3.

14 "Civil Disturbances in Guatemala," CIA National Intelligence Estimate, April 3, 1962, JFKL, POF, Country Files, Guatemala, Box 118, Folder 6.

${ }^{15}$ Bell to CINCARIB, March 15, 1962, JFKL, POF, Country Files, Guatemala, Box 118, Folder 6.

${ }^{16}$ JSC to Generals Smith, Adams and O'Meara, March 15, 1962, JFKL, POF, Country Files, Guatemala, Box 118, Folder 6. 
${ }^{17}$ Thomas and Marjorie Melville, Guatemala: The Politics of Land Reform, (New York: Free Press, 1971), pp. 146-6.

${ }_{18}$ Ydigoras, My War With Communism, P. 204.

${ }^{19}$ Bell to Bundy, April 20, 1962, JFKL, POF, Country Files, Guatemala, Box 118 , Folder $6 \mathrm{i}$.

${ }^{20}$ Abraham F. Lowenthal and J. Samuel Fitch, eds., Armies and Politics in Latin America, (New York: Holmes and Meirer, 1985), p. 207.

${ }^{21}$ Michael McClintock, The American Connection Volume Two, State Terror and Popular Resistance in Guatemala, (London: Zed Books, 1986), p. 52.

${ }^{22}$ Brian Jenkins an̉d Cesar D. Sereseres, "U.S. Military Assistance and the Guatemalan Armed Forces," Armed Forces and Society, Vol. 3, No. 4 , (Fall 1997), pp. 579-83.

${ }^{23}$ Jerry L. Weaver, "The Military Elite and Political Control in Guatemala, 1963-1966," Social Science Quarterly, Vol. 50, No. 1, (June 1969), pp. 37-9.

${ }^{24}$ Bell to Rusk, August 14, 1962, JFKL, NSF, Country Files, Box 101, Folder 1: Guatemala, General.

${ }^{25}$ Susanne Jonas, The Battle for Guatemala: Rebels Death Squads and U.S. Power, (Boulder: Westview Press, 1991), p. 66.

${ }^{26}$ James Dunkerly, Power in the Isthmus, p. 445.

${ }^{27}$ Ydigoras, My War With Communism, p. 226.

28 "Planned Coup by Guatemalan Generals," CIA National Intelligence Estimate, Dec. 28, 1962, JFKL, NSF, Country Files: Guatemala, General, Box 101, Folder 3, Sept. 1962-Dec., 1962.

29 Jerrold S. Buttrey, "The Guatemalan Military 1944-1963, (Texas, Austin, 1967), pp. 225-226.

30 "Possibility of a Preventative Coup," Nov. 12, 1962, JFKL, NSF < Country Files: Guatemala, Box 101, Folder 3, Sept. 1962-Dec. 1962.

31 Richard Gott, Guerrilla Movements in Latin America, p. 44.

${ }^{32}$ Cesar D. Sereseres, "Military Development and the U.S. Military Assistance Program for Latin America," ( $\mathrm{PhD}$. diss. University of California, Riverside, 1971), p. 55. 
33 "Meeting With President Ydigoras," March 25, 1963, JFKL, NSF, Country File: Guatemala, General, Box 101, Folder 4, Jan.-March 1963.

${ }^{34}$ CIA National Intelligence Estimate, March 27, 1963, JFKL, NSF, Country File: Guatemala, General, Box 101, Folder 4, Jan. 1963-March 1963.

${ }^{35}$ Ibid.

36 "Return of Arevalo," March 27, 1963, WNRC, RG 286, OPS, Box 60, Folder: Guatemala, General, 1963.

${ }^{37}$ El Imparcial, April 1, 1963, pp. 1, 7.

${ }^{38}$ Miami Herald, Dec. 24, 1966, p. 4.

${ }^{39}$ Edwin Martin to the authors, Stephen Schlesinger and Stephen Kinzer in Bitter Fruit: The Untold Story of the American Coup in Guatemala, (New York: Doubleday, 1983), pp. 243-4.

${ }^{40}$ President Kennedy's News Conference, April 3, 1963, Lyndon Baines Johnson Library (hereafter LBJL), NSF, Country File, Latin America, Box 2, Folder: Latin America, Vol I, Jan 1963-Dec. 1963.

${ }^{41}$ Cesar D. Sereseres, (diss.), pp. 65-67; Jerrold Buttrey, (diss.), pp. 209-212; Weaver, "Military Elite and Political Control in Guatemala 1963-1966," pp. 41-42.

42 "Counter-insurgency Base in Guatemala," DOD Telegram, June 10, 1962, JFKL, NSF, Country Files, Guatemala, Security Box 101, Folder 3., April 1962-July 1962.

${ }^{43}$ Susanne Jones and David Tobis, Guatemala, (New York: North American Congress on Latin America, 1981), pp. 180-1.

${ }^{44}$ McClintock, The American Connection, p. 56.

${ }^{45}$ Office of Public Safety 1962 Budget, Guatemala, WNRC, RG 287, OPS, Box 61, Folder: Guatemala, General; Prados, Presidents' Secret Wars, p. 184; Blanche Cook, Declassified Eisenhower, (New York: Penguin Books, 1984), p. 221.

${ }^{46}$ Cesar D. Sereseres, "Military Development and the U.S. Military Assistance Program for Latin America," (PhD. diss. University of California, Riverside, 1971), p. 193.

${ }^{47}$ McClintock, The American Connection, pp. 56-7.

48 Harold Hovey, United States Military Assistance to Latin America, (New York: Praeger, 1970), p. 417. 
49 "Military Assistance and Advisory Group, Guatemala --Outline of Priorities,", May 12, 1964, LBJ, NSF, Country File, Latin America, Box 2, Folder: Country File Latin America, Item 60.

${ }^{50}$ Brian Jenkins and Cesar D. Sereseres, "U.S. Military Assistance and the Guatemalan Armed Forces," p. 46.

${ }^{51}$ Alejandro de Corro, "Los commissionados militares en Guatemala, 1963-1966", Estudios Centroamericanas, Vol. 17 (Spring 1972), No. 12, p. 49-52.

52 Ibid, p. 56.

53 "CONDECA Inaugural Ceremony," Dec. 14, 1963, LBJL, NSF, Country File, Latin America, Box 1, Folder Latin America, Vol 1, item 32.

${ }^{54} \underline{\text { Ibid }}$

${ }^{55}$ El Imparcial, Oct. 12, 1964, p. 3.

${ }^{56}$ From Office of the Secretary of Defense, Civil Affairs School, Fort Gordon, GA, 1964 (See Barber and Ronning, Internal Security, p. 102)

57 U.S. AID "Office of Public Safety Termination Phase-Out Report," (Washington, DC: GPO, 1975), p. 71.

${ }^{58}$ Robert L. Peterson, "Guatemala" from Ben G. Burnett and Kenneth F. Johnson, eds., The Political Forces in Latin America: Dimensions of the Quest for Stability, 2nd ed. (Belmont, CA: Wadsworth Publishing Co., 1970), p. 771.

59 John Saxe-Fernandez, "The Central American Defense Council and Pax Americana," from Latin American Radicalism, ed. by Irving Louis Horowitz et al, (New York: Random House, 1969), p. 88.

${ }^{60}$ Cesar Montes, "Una ruptura logica y necesaria," Punto Final, No. 53, 23 (April 1968), p. 47. 


\section{CHAPTER V}

\section{VIETNAM ON THE ISTHMUS: THE U.S. LED COUNTER-INSURGENCY WAR IN GUATEMALA 1966-1967}

At midnight on March 3, 1966, some one hundred and fifty members of the Guatemalan Judicial Police, led by U.S. trained military intelligence officers, raided three residences in Guatemala City. The central committee of the outlawed Guatemalan Communist Party (PGT) conducted its monthly meetings in the first house. In the other two residences, members of the legal Federacion Nacional de Campesinos (FNC), Guatemala's largest peasant union, gathered to discuss strategies for the upcoming Presidential election, only three days away. The Judicial Police arrested twenty-eight men from the three houses, among them Victor Manuel Gutierrez, secretary-general of the Communist Party, and Leonardo Castillo Flores, Guatemala's most famous union leader and the head of the FNC. ${ }^{1}$

The police immediately took about two-thirds of "the twenty-eight" to a secret military post in the countryside where they summarily executed them. The more important of the "twenty-eight" were interned in basement cells at Judicial Police Headquarters. There, over the course of the next three days, the police interrogated, tortured and eventually executed each and every one of them. Some of the bodies were apparently flown to remote jungle locations where they were hacked to pieces with machetes and their fragments strewn over a number of burial pits, the standard Judicial Police method for disposing of political prisoners. In the case of the more important personages, Gutierrez and Flores, reports later surfaced that the military flew their bodies out over the Pacific in American UH-1 helicopters and dumped them into the 
sea, a technique commonly used against captured Viet Cong (VC) and National Liberation Front (NLF) leaders in South Vietnam. ${ }^{2}$ In any case, none of the twenty-eight were ever heard from again.

This strike, the first major offensive by the new elite U.S. trained CT (Counter-Terror) Detachment and CI (Counter-Intelligence) Unit ushered in the start of a savage new phase in the counter-insurgency war in Guatemala, prosecuted by both the United States and Guatemalan militaries. This escalation to all-out war in Guatemala eerily mirrored a similar process occurring eight thousand miles away in South Vietnam. There, too, by the mid-1960s, the Johnson White House eschewed earlier more surgical methods of increased internal repression, military advice and training, air and combat support in favor of direct military intervention by U.S. ground forces. The numbers of U.S. troops deployed in Guatemala remained classified and controversial to this day, but the Johnson Administration clearly opted for a more direct approach to attain its politico-strategic goals just as it did in Southeast Asia and the Dominican Republic in 1965.

Johnson's Assistant Secretary for Latin American Affairs, Thomas Mann, became the chief architect of the President's departures from the Kennedy Doctrine in Latin American policy. Although an early enthusiast for the Alliance for Progress in 1961, Mann had a reputation as a veteran, hard boiled pragmatist when it came to the Cold War in Latin America. He announced in 1964 that the United States would adopt a more "realistic policy for dealing with Latin American military governments." There would be "no more good guys and bad guys." All military juntas would get carrots and Washington virtually threw away its rather seldom used stick. Preoccupied with the 
civil rights movement at home and military escalation in Southeast Asia, Johnson lost interest in social reform south of the Rio Grande. Stepped up counter-insurgency war proved the natural result of the Mann Doctrine, not just in Guatemala, but in Venezuela in 1964, in Colombia 1964-1968, in Peru in 1965, and in Nicaragua, Honduras and Bolivia in 1967. The U.S. run Murder Incorporated Johnson expressed shock at discovering in the Caribbean soon spread to the entire Hemisphere. Johnson's increasingly militaristic approach to Latin America, forgotten due in part to all the opprobrium heaped upon him for the Vietnam War, more closely resembled Ronald Reagan's than any recent president. Indeed, while Reagan fought four counter-insurgency wars in Latin America, Johnson conducted eight. His administration soft peddled economic development as the cure for Latin American instability and increasingly brought out the heavy artillery in support of authoritarian regimes.

Peralta's so-called "military caretaker" government gave only a limited stability to Guatemala in the years 1963-1966. Under Colonel Peralta, the military emerged as a dominant force though it still ruled with the acquiescence of a larger coalition of interests. Senior officers occupied the center of this coalition which also included foreign and domestic economic interests and a newer breed of technicians and administrators that arose ironically as a consequence of Alliance for Progress economic investments and reforms. ${ }^{3}$

The Kennedy Administration's emphasis on technical training and education for Guatemalan civilians (as well as the military), combined with the increase in development and the expansion of the Guatemalan government, created a need for a 
new indigenous class of managers and technicians. Most of these bureaucrats and specialists were ladinos and by the mid-1960s emerged as a crucial, new political group. What proved ironic is that this technocratic class, which the Kennedy Administration banked on to lead Guatemala to democracy, became among the strongest supporters of military rule. They were, after all, committed and dependent upon capitalist economic development and investment (many were lower and middle level managers of U.S. awned Guatemala based firms) and an expanded government bureaucracy (others were civil servants for the government's new tepid social programs). These middle-class technocrats regarded the prospect of a socialist revolution in Guatemala, the guerrilla program, with as much trepidation as the U.S. trained military. ${ }^{4}$

The traditional landed oligarchy also supported the Peralta regime as a bulwark against Communism or even worse, serious reform. But beginning in the mid-1960s, the U.S. emboldened military increasingly shunted the oligarchy aside and usurped it as the real political ruler of Guatemala. As Mexican political scientist Edelberto Torres-Rives put it, "Once the Army needed the oligarchy but now the oligarchy, surrounded by guerrillas and caught up in a changing economy, needed the Army."

Peralta appointed scores of officers to key cabinet and top level government administrative posts. While Peralta relied on the expertise of civilian technocrats, he always wanted military officers above them. Indeed the civil administration courses taught to Guatemalan officers at the U.S. School of the Americas encouraged this trend. Peralta increased military salaries and encouraged officers to acquire plantations, cattle ranches and private businesses of their own. One of the striking aspects about 
Guatemalan officers until the 1960s was -- with the exception of a few corrupt generals -- how poor they all were. Though proud of their traditions, insular, clannish and elitist, the majority of officers lived in substandard housing on military bases with their families. Many "moonlighted" on the side as maintenance workers and night foremen to supplement meager salaries. ${ }^{6}$

In 1965 under Peralta, the military acquired their own bank, named quite brazenly Banco de Ejercito (Army Bank) which invested heavily in U.S. manufacturing and food processing franchises. Peralta established a huge pension and military investment fund called the Institute for Military Social Security (IPM). The IPM provided start-up capital for the Guatemalan Bank of America. ${ }^{7}$ Officers began drawing double salaries as body guards and security personnel for U.S. businessmen, landowners and corporations. They charged "security fees" for new foreign enterprises. With opposition newspaper increasingly shut down and censored the Army's newspaper, Ejercito , gained a larger prominence and circulation. In 1965 the military established its own political party, the Partido Democratico Institutional, Democratic Institutional Party (PID) which almost overnight became a major player on the Guatemalan political scene. In 1966 the PID fielded a presidential candidate and a full slate of congressional candidates. Its positions on domestic issues often proved sacrosanct. As one Christian Democratic leader, Danilio Barillas, complained "we can get out the votes, but they (the PID) can get out the tanks." ${ }^{8}$ Richard N. Adams' 1970 Crucifixion by Power and Jerry L. Weaver's 1969 "The Military Elite and Political Control in Guatemala 1963-1966" in Social Science Quarterly illustrate the corporatist nature and political ascendency of the Guatemalan military in this period. Their analysis 
of the military's institutional expansion and unprecedented political opportunism could serve as a model for similar government take-overs by generals and colonels throughout Latin America in the 1960s. Jim Handy, in his underrated 1985 Gift of the Devil takes a post-revisionist approach to the creation of a garrison state in Guatemala, bringing in larger cultural, historical, racial, and even religious elements which helped the Guatemalan military to view itself as the only possible savior of the nation.

By the early 1970 ș this trend of the military becoming an economic corporation indivisible from the state reached full flower. Military men ran 46 semi-autonomous state institutions. They owned a cement factory Cementos Gustatoya, a radio and television station, several factories and mining operations as well as the 800 unit Santa Rosita housing project and a multi-storied parking building in downtown Guatemala City. ${ }^{9} \quad$ Like the Kennedy Administration, the Johnson White House supported the Guatemalan Army as the one institution best capable of managing Guatemala. "The military forces are the decisive power element and determinant of stability," a State Department memorandum to the White House read. In a racist twist it continued "...popular opinion and interest in democracy as a whole tends to be apathetic in Guatemala. Only in the heat of a well publicized campaign or when the mass man himself comes under unusual stress does he arouse himself to make his opinions felt." ${ }^{10}$

But even the new administration was taken aback by the acquisitive corporate greed that military rule eventually spawned. "The military are beginning to take on a vulture-like aspect," a later CIA report stated, "in acquiring properties from arrested and executed suspects." ${ }^{11}$ 
Traditionally the Guatemalan Army had been an arbiter between various political and economic factions within Guatemalan society, the conservatives and the liberals, the landowners and the growing urban business elite. The Army was often a political stepping stone for ambitious officers like Jorge Ubico and Miguel Ydigoras Fuentes to run for the presidency. At times the Guatemalan Army attached itself to a particular political party or figure in order to maintain the balance of forces within Guatemala such as when it supported the Revolutionary Party of Arevalo and Arbenz during the Revolutionary "ten years of spring", 1944-1954. At this juncture the Army felt its traditional benefactor, the landed oligarchy, had become too dominant. ${ }^{12}$

By the mid-1960s, however, due in no small part to the United States' military aid and indoctrination, the Guatemalan military had gone from the guardian of political order to the absolute masters of Guatemalan society. Proud landowners and even foreign corporations bowed as supplicants before Peralta and his junta, seeking support and favors from a military they had once controlled. Had the U.S. not built up the Guatemalan military into such a powerful, modern, highly skilled and uniquely equipped institution, the new technocratic and educated ladino civilian class might have eventually gained dominance over the landed oligarchy and instituted at least some meaningful reform. But by its elevation of the military to the supreme seat of power, the United States perhaps even unwittingly choked off this last possibility for peaceful reform in Guatemala.

As the Guatemalan military became a major economic player, it increasingly regarded the rising ladino elite as a competitor and its rather moderate reform sensibilities as treason. Thus the United States warped economic development at the 
same time as it encouraged it. The frustration of the educated ladino engineers, teachers, managers, and administrators intensified by the late 1960 s as the military subordinated them to political impotence and turned violently against any who dared to speak out. A guerrilla leader, Camillo Sanchez, crystallized this conflict:

If you keep giving one group of men more and more guns and you keep giving another group of men more and more books, who do you think is going to become the most powerful? And who do you think is going to become the most frustrated? You Americans have created your own revolution so I cannot feel sorry for you. ${ }^{13}$

The political and social crisis which led to open warfare in 1966 actually began the previous year. Peralta and the United States' steady yet measured build-up of the Guatemalan military and security forces brought increasing repression especially in the countryside and among Guatemalan students at the University of San Carlos. One political analyst noted that during the eight-year period between January 1962 and January 1970, the Guatemalan people lived under a government instituted state of siege for 58 out of 96 months. ${ }^{14}$ Raids and security sweeps of the University became an almost daily event with respected professors dragged out of packed lecture halls at gun point and student leaders beaten to a bloody pulp in their dorms. In the countryside to the already increased repression of the vastly expanded military commissioners system, the Peralta regime added the Policia Militar Ambulante (PMA) or Mobile Military Police. Formed in 1964, this new counter-insurgency police force of 1,000 men was established by Decree Law 332 "to lend police service in the rural areas of the Republic." Articles 5 and 6 of the Decree stated:

The PMA shall lend assistance in cases of emergency, to the owners and administrators of estates, haciendas, agricultural lands, forests and all rural properties...[and] observes all activity that tends to inflame passions among the 
peasant masses or in the rural communities and when necessary repress through licit means any disorder that shall occur. ${ }^{15}$

In response to the government's ever tightening grip in the countryside, Yon Sosa's and Turcios Limas' guerrilla groups stepped up their attacks focusing on assassinating well-known brutal landlords and kidnapping others for ransom. The FAR raised some $\$ 500,000$ from kidnapping and robberies between 1964 and $1966 .{ }^{16}$ These funds helped purchase more weaponry and also funded "the April 12 Front," a student resistance movement in the capital. Not all of Washington's concern over Castroite links with the guerrillas proved unfounded. Castro gave moral and political support, some money, and tactical and strategic advice to the guerrillas. Turcios Lima traveled to Havana in 1965 to meet with Castro. David A. Crain's insightful 1975 article "Guatemalan Revolutionaries and Havana's Ideological Offensive of 1965-1968" supplies the best account of Cuban-Guatemalan guerrilla links. He beautifully illustrates the irony of the supreme anti-imperialist Castro attempting to dominate all the guerrilla movements of Latin America. While the Guatemalan guerrilla movement was still relatively small at this stage, CIA and State Department officials no doubt remembered that Castro and Che Guevara had started out with only a handful of men in the Sierra Maestra in Cuba in 1955 yet eventually overthrew Batista's regime and its 50,000 man, American equipped army. The guerrilla movement's increasing Communist indoctrination alarmed Washington and ended the trivializing of the movement by dissenting analysts as "basically a bunch of bandits." 17

In 1965 the two main guerrilla movements split due to political bickering and Yon Sosa's disgust with the lethargic Guatemalan Communist Party. Yon Sosa's 
MR-13 broke away from FAR and espoused a Trotskyite, pro-Chinese line while Turcios Lima's "Edgar Ibarra Front" (named for a murdered student) remained in the FAR and continued to align itself with the Guatemalan Communist Party (PGT), Moscow and Havana. ${ }^{18}$ Neither the Guatemalan nor United States governments has yet to document a substantial weapons link between the guerrillas and Castro. The Guatemalan guerrillas stole or bought about $80 \%$ of their weaponry from the Guatemalan Army (the remaining $20 \%$ came from private arms purchases in Mexico and Costa Rica). ${ }^{19}$ In another similarity with Vietnam, American military advisors frequently expressed outrage at how many U.S. weapons ended up in the hands of guerrillas due to corrupt or politically sympathetic Guatemalan officers. The Viet Cong also fought and killed numerous U.S. advisers with M-16s and American made hand grenades and mortars in this period purchased from the Army of the Republic of Viet Nam (ARVN). Castro did send some medical supplies and small amounts of ammunition to the guerrillas. A few Cuban volunteers fought with the FAR but even CIA Intelligence estimates discounted any substantial Cuban role. ${ }^{20}$ Whether Cuban support might have increased in the future remained a legitimate concern for American advisers. Castro had a documented record of adventurism in Latin America, in Venezuela in 1963 and Bolivia in 1967, and loved to stir up trouble for the United States wherever possible but from his vantage point, having survived one invasion, numerous sabotage attacks and several assassination attempts by the CIA, Castro probably regarded his own limited interventions as morally justified.

On February 5, 1965, MR-13 urban gunmen assassinated the chief of the United States military mission, Colonel Harold Hauser, in his car while he was driving home 
from the U.S. Embassy. In a public statement MR-13, cognizant of the links between U.S. policy in Guatemala and Vietnam, claimed the act "constituted the response of the Guatemalan people to the criminal acts of Yankee imperialism in North and South Vietnam."21 Peralta declared a state of siege (the last one had just ended two months previously) and suspended even the 1964 military constitution. A day later rebels burnt down the United States Agency for International Development's (AID) motor pool garage. They threw a hand grenade at Peralta (it bounced off his jeep and landed in a crowd of civilians, killing several) and blew up Army trucks in the capital. In April and May they machine-gunned the Guatemalan Army headquarters and the U.S. Consulate. On May 21, they assassinated the Deputy Minister of Defense, Colonel Erresto Molina Arreaga, near his home. In June, MR-13 launched bomb attacks against seven Latin American Embassies in the capital, all belonging to nations that supported the U.S. invasion of the Dominican Republic. ${ }^{22}$ The Guatemalan guerrillas regarded the Dominican Invasion as a crucially significant event which might presage a U.S. invasion of Guatemala or even Cuba. Occurring as it did at the very moment the Johnson Administration decided to introduce U.S. ground combat troops to South Vietnam, it seemed part of a larger all-out American offensive against Third World nationalism under the familiar guise of anti-communism. The Johnson White House was also cognizant of the significance of this step. The invasion amounted to the first clear-cut violation of the thirty-two year old Good Neighbor Policy of Franklin Delano Roosevelt. Unlike the 1954 Guatemalan coup and 1961 Bay of Pigs invasion, which largely employed surrogates, the Dominican Invasion deployed U.S. combat troops -22,000 of them. It also violated the Organization of American States' Charter on 
non-intervention. Troubled by the escalation in Vietnam, yet criticized by domestic conservatives for not standing up enough against communists, Johnson apparently hesitated to make this commitment. Mann and Rusk, on the other hand, urged him to send in the Marines and paratroopers. This invasion actually constituted the logical outcome of Washington's obsession since 1959 of deterring a "second Cuba," the essence of the whole Kennedy Doctrine in Latin America.

Confronted with the Guatemalan military government's apparent impotence before the guerrilla offensive, the White House's initial enthusiasm for Peralta began to wane. A June 22, 1965, CIA National Intelligence Estimate sent to President Johnson stated:

The Peralta regime, despite its effectiveness in reducing corruption has been unable to take any affirmative decisions in the economic and social fields which would have contributed to progress and to reduction of counter-insurgency problems. The Government has been unable or unwilling to eliminate guerrilla groups although sporadically aggressive patrol activity by the military has succeeded in keeping them somewhat off balance...

The U.S. should undertake in various low key ways, including direct personal contact to make known to Peralta the U.S. view that an early return to constitutional government is essential and emphasizing the U.S. concern that failure to move in this direction enhances the possibility of subversion or civil war...Further the U.S. should encourage Peralta to permit all "middle of the road" political parties to present candidates for the presidency. ${ }^{23}$

By the fall of 1965, the Peralta government agreed, with some reluctance, to hold presidential elections in March of 1966 . Several underlying reasons can be listed as to why Peralta decided to relinquish at least some of the reins of absolute power and why the United States wanted a "more legitimate" government as well. First, Peralta was confident that the military would retain most of the instruments of power even under a civilian president just as the military had in the last year of Ydigoras' reign. 
Second, Peralta and his advisors felt their governmental party, the PID, had a reasonable chance of winning the election. Indeed in the final tally, the Institutional Democratic Party (PID) polled second to the Revolutionary Party (PR) winner, Julio Cesar Mendez Montenegro. And since the military government ran the election, there always existed the possibility it could rig the results right up until election day. Third, Peralta remained unwilling to assume a permanent position as Chief of State. Though a ruthless anti-Communist, and a fierce champion of the Guatemalan military, Peralta had a reputation for personal integrity. Unlike his two predecessors, he did not enrich himself in office, lived modestly, and weeded out considerable corruption as even his opponents grudgingly admitted. "Peralta was a bastard," guerrilla Pablo Momsanto said, "but he was an honest bastard. ${ }^{24}$ Fourth, the influence of the United States helped force the military's hand. A stiff necked nationalist, Peralta often rejected and obstructed U.S. policy in Guatemala, yet with a military and an economy as dependent as his on Washington, he had to take the American viewpoint into account. ${ }^{25}$

Its reputation still stinging from the angry Latin American denunciation of its Dominican Republic invasion, the Johnson Administration sought some political cover in a Guatemalan free election, the first in eight years. It hoped a civilian government would diffuse guerrilla resistance and perhaps even implement some economic reforms to further negate the social causes of insurgency. More cynically, the Johnson Administration realized conducting a savage counter-insurgency war under the guise of a civilian government could prove more politically palatable than under a military one. Frustrated with Peralta's obduracy, the White House felt it could achieve its military aims more easily under a pliable civilian government, vulnerable to a military coup and 
dependent on U.S. political support for survival. "A civilian government might prove much more amenable to our security needs," the new U.S. Ambassador, John Gordon Mein, wrote to Dean Rusk. ${ }^{26}$ Even before the actual election, the U.S. showed a propensity for influencing and manipulating the leading candidate, Mendez Montenegro, a former law professor at the University of San Carlos. A State Department telegram to the U.S. Embassy in Guatemala City, dated February 14, 1966 stated:

We wonder whether the confidence gap between MM (Mendez Montenegro) and the military- conservatives cannot be bridged. We wonder for example whether MM could not reassure the business community on how far he proposes to go in economic and social reforms and the military establishment on the future status of their programs and control of communist activities. We recognize that the mechanism for accomplishing this may be difficult to assemble... ${ }^{27}$

Through its savage, sudden annihilation of "the 28 ", the Guatemalan military delivered an unmistakable message to all political parties that it would continue to manage the domestic security affairs of Guatemala. The United States issued no protest against this clear violation of human and constitutional rights and on the contrary congratulated the government "on its recent success in disrupting communist subversive activities. ${ }^{.28}$ The government held elections on March 6, 1966, in an atmosphere of fear, terrorism and intimidation.

\section{TABLE XIV ${ }^{29}$}

\section{March 6, 1966 Guatemalan Presidential Elections}

$\begin{array}{llll}\text { Candidate } & \text { Party } & \text { Votes } & \text { Percentage } \\ \text { Julio Cesar Mendez Montenegro } & \text { PR } & 199,545 & 43.9 \% \\ \text { Colonel Juan de Dios Aguilar } & \text { PID } & 145,863 & 32.1 \% \\ \text { Colonel Miguel Argel Ponciano } & \text { MLN } & 109,386 & 24.0 \%\end{array}$


Since none of the three candidates gained an absolute majority, the National Congress would have to decide the election in a special May 5 session. While the new Constitution allowed illiterate Indians to vote for the first time since 1954, government repression in the countryside discouraged even a moderate Indian turn-out. The table below shows the problem of judging the legitimacy of Guatemalan elections in this period.

TABLE XV $\mathrm{XV}^{30}$

- Guatemalan Election Results 1958-1970

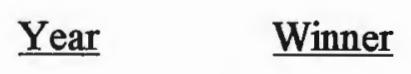

1958 Miguel Ydigoras Fuentes

1963 Elections canceled

1966 Julo Cesar Mendez Montenegro

1970 General Carlos Arana Osario $\underline{\text { Abstention }}$

$33.2 \%$

$43.7 \%$

$46.2 \%$
Adult Population Voting for the Winner

$$
12.7 \%
$$

$10.0 \%$

$10.5 \%$

Guatemala certainly qualified as an extremely "limited democracy", although it should be noted that some of these figures are not far off from recent U.S. presidential elections.

With no clear winner and the moderate-leftist Revolutionary Party in the lead, rumors spread of a military coup to overturn the results and seat the Army's PID candidate and Peralta favorite, Colonel Aguilar. Secretary of State Dean Rusk, in a March 10 telegram, instructed Ambassador Mein that a message be "conveyed to Peralta that the White House would like to see the results fully respected and power transferred peacefully. ${ }^{131}$ 
The United States, through Ambassador Mein, helped broker an arrangement between Mendez Montenegro and the military. A memorandum written by Bill Moyers for President Johnson described the main points of the deal:

Peralta and other military leaders have worked out an agreement with Mendez Montenegro under which Mendez will be allowed to assume office in exchange for the following guarantees - 1) naming of the Defense Minister and other heads of security departments by the military; 2) a continued and uninterfered crackdown on Communists and subversives; 3) no prosecution of military personnel for past misdeeds. ${ }^{32}$

It was later learned that this pact also included the military's right to appoint all base and zone commanders, to have complete control over the military budget and not to permit any radical elements, i.e., the supporters of Arevalo, Arbenz, Villagram Kramer, and Lucas Caballeros (all four leftist-moderate political leaders) to participate in the government. ${ }^{33}$ This agreement clearly violated the Guatemalan Constitution and created in effect two governments within Guatemala -- a civilian government responsible for social policy severely restricted by the agreement; and a military government which had the authority to wage its own private war, free from civilian oversight.

Mendez Montenegro was no doubt aware of the Faustian nature of this deal. Former admirers and allies on the left criticized him harshly for selling out his administration before he even got started. Given his political weakness -- the military and the U.S. held all the cards -- what real choices did the president-elect have? Right-wing gunmen assassinated his brother Mario, the original PR's presidential candidate, in October 1965. Julio Cesar Mendez Montenegro demonstrated considerable physical courage, picking up the mantle of his slain brother and running in the election against a brutal regime supported by numerous right-wing fanatics. 
Mendez Montenegro apparently hoped to isolate the more rightist elements within the country and the military by broadening his moderate base of support through reform legislation. With his liberal background, he also mistakenly expected to enjoy a special relationship with the United States. But having helped install him, Washington quickly left the president dangling in the wind, nudging him if anywhere to the right, particularly on security issues. Under its Mann Doctrine, the Johnson Administration preferred strict anti-communists to liberal political leaders, which the Kennedy Administration had at least lent some moral support.

At his inauguration on July 1, 1966, surrounded on the dais by military officers and a throng of machine-gun toting commandos, Mendez Montenegro offered full amnesty to any guerrillas who would give up the struggle and join the legitimate democratic process. Confidants of the president say he wore a bullet-proof vest that day and carried a loaded .45 caliber pistol under his suit. He never went anywhere in the next four years without being similarly equipped, not because he feared the guerrillas, but because he feared his own Army bodyguards. ${ }^{34}$ Following a drum roll and orchestral flourish, U.S. Ambassador Mein congratulated the sweating president on "the return of democracy to Guatemala."135

The guerrillas rejected Mendez Montenegro's amnesty offer and shortly afterwards the Guatemala military attacked them with a savagery seldom witnessed under Peralta's military regime. Paradoxically, as political scientist Cesar D. Sereseres has pointed out, Mendez Montenegro had everything to gain and nothing to lose in agreeing to the all-out U.S. supported final solution to the guerrilla dilemma. Fighting a war in the countryside kept the military occupied and left them neither the time nor 
the inclination to launch a coup d'etat against his government. Mendez Montenegro shored up his position with suspicious rightists in the MLN and PID by proving more bellicose than Peralta in ferreting out and destroying Communist rebels. By instituting an aggressive counter- insurgency campaign, Mendez Montenegro held his hand on a lever that would enable him to demand more economic aid from the United States government than ever before. Here, after all was a popularly elected law professor -- of all occupations -- fighting a lone heroic battle against Communist guerrillas in the Western Hemisphere. What conservative Congressional Committee could deny him all the economic aid he requested? Any additional military aid garnered only boosted his prestige with the Army. ${ }^{36}$ The war, however, rapidly escalated into a horrendous tragedy in which the security forces butchered hundreds of Mendez Montenegro's sincere supporters. The president had concluded a truly Faustian deal whose dimensions he probably failed to imagine the day he signed the pact at the National Palace.

The Guatemalan Army, which between 1963 and 1966 had increased 50\% from 8,000 to 12,000 men, struck hard on October 1,1966 , in the eastern departments of Izabal and Zacapa. The counter-insurgency campaiga was directed first at controlling the vital and often attacked Atlantic Highway, then rapidly spread out to the adjoining rural areas that had come under control of the FAR- Rebel Armed Forces. The operation which had required months of logistical and training preparation proceeded on an unprecedented scope and scale. The U.S. 1965 creation of a central maintenance facility, a central supply depot, and a central Recruit Training Base proved an essential logistical prelude to this operation. ${ }^{37}$ UH-1 Army helicopters airlifted elite Guatemalan 
paratroop and Special Forces strike units directly on top of guerrilla controlled villages. Others flew into rapidly constructed airstrips on C-47 transport planes. Thousands more drove in on trucks and newly supplied M-113 armored personnel carriers along recently built civic action roads. A few specialty units even launched amphibious assaults in U.S. donated 40 foot CGUB patrol boats and 85 foot CPB amphibious landing craft. ${ }^{38}$ "Suddenly from out of nowhere," one of the few rebel survivors, Alvarado Lopez, recalled, "there were thousands of soldiers everywhere. They parachuted from the sky, they landed in helicopters, they poured in on armored cars...And always they were led by the American Green Berets. ${ }^{139}$

How many U.S. Green Berets took part in this operation remains a matter of considerable dispute. Chicago Daily News correspondent Georgia Anne Geyer reported up to a thousand Green Berets from the Eighth Special Forces Group in Panama flew in for the operation (the unit had a strength of 1,400 men). ${ }^{40}$ They not only led Guatemalan Army units but served as direct combat troops. Because of the intensive rotation policy of the Green Berets, nearly two-thirds of the Eighth Special Forces had Vietnam experience. They represented an indispensable, highly skilled veteran anti-guerrilla force. The Defense Department denied the figure of 1,000 but admitted to having nine Special Forces Mobile Training Teams (MTTs) in Guatemala in the summer and fall of 1966 . With a normal strength of between twelve and thirty-six men, these nine MTTs could comprise over three hundred Green Berets. But according to guerrillas, several U.S. correspondents and even members of the Guatemalan military, the figure was much higher. The Pentagon admitted twenty-eight Green Berets died in combat in Guatemala 1966-1967, supposedly while "advising 
Guatemalan units." Again, these figures are disputed. Green Beret Vietnam and Guatemalan veteran Donald Duncan puts the figure at least three times higher. ${ }^{41}$ The Pentagon could have used several methods to lower the Guatemalan Green Beret body count. One is by adding combat dead to those Eighth Special Forces soldiers who died in training exercises in Panama in 1966-1967. Another even more novel concept, according to Donald Duncan, was that the U.S. Army flew Green Berets rotating out of Vietnam directly to the Canal Zone and Guatemala. If they were killed or wounded in the Guatemalan operation their names went onto the Fifth and Seventh Special Forces Vietnam casualty lists. ${ }^{42}$ According to this theory perhaps as many as a score of the Green Berets listed on the Vietnam Memorial in Washington died in Guatemala, not Vietnam.

The U.S.-led regular and elite troops swept through the villages of Zacapa and Izabal and worked in close cooperation with paramilitary irregulars, Military Mobile Police (PMA) as well as the crucial military commissioners. These paramilitary forces walked along the lines of prisoners and pointed out guerrilla sympathizers or suspects in the same manner as Vietnamese Civil Guard, Phoenix operatives and Kit Carsons pointed our VC suspects to ARVN and U.S. military during village sweeps in the Delta and Central Highlands. The PMA summarily executed most suspects. Others were taken away for interrogation and internment in "Tiger Cages" (La Tigrera) at Judicial Police Headquarters similar to those in the notorious Con San prison in Vietnam or in cells known as "the Stables" (Las Cuardas) at National Police Headquarters. The police used electronic and water torture methods commonly practiced in Vietnam ${ }^{43}$ 
The Army also relocated hundreds of Guatemalan villagers to resettlement camps where they forced them to bear arms and vow their allegiance to the government. Political scientist Susanne Jonas referred to these camps as "the strategic hamlets of Guatemala." The commander of the Zacapa operation, Colonel Carlos Arana Osario, later known as the "Butcher of Zacapa," conducted a particularly brutal scorched earth campaign in his department, burning villages, destroying crops, killing livestock and turning guenrilla support areas into wastelands. He referred to his efforts in Vietnam double speak as a "pacification campaign."44 New Left historian, Susanne Jonas, remains probably the foremost authority of human rights abuses in Guatemala in this period and has compiled an impressive amount of research, beginning with the 1974 Guatemala, continuing with 1984's Guatemala: Tyranny on Trial and her most recent 1991 The Battle for Guatemala: Rebels, Death Squads, and U.S. Power. Jonas relies heavily on Guatemalan sources, particularly oral histories of the victims of atrocities. At times her work degenerates into flat-out anti-American diatribes with a strong Marxist undertone, nonetheless, her studies provide invaluable data on the inhumanity and barbarity of counter-insurgency in Guatemala which more conventional historians often treat in far too clinical terms.

Many other military tactics used in Guatemala also fit into classic Vietnamese counter-insurgency doctrine. The Guatemalan Army and Air Force supplied close air support with UH-1 helicopters gunships and fixed wing aircraft. They strafed, bombed, defoliated and napalmed villages using the infamous Dow Chemical jellied gasoline for the first time in the Western Hemisphere. Unconfirmed reports claimed United States 
Air Force bombers flying from the Canal Zone joined in on these operations. ${ }^{43}$ This might not have even been necessary as MAP funding had furnished the Guatemalan Army and Air Force with sufficient combat aircraft of its own. As Ambassador Mein said in a ceremony upon the delivery of five new HU-1B jet powered helicopters:

These articles, especially the helicopters, are not easy to obtain at this time since they are being utilized by our forces in the defense of liberty in Southeast Asia. But liberty must be defended wherever it is threatened and that liberty is now being threatened in Guatemala. ${ }^{45}$

The Guatemalan Air Force designated areas fraught with guerrilla activity zonas libres ("free fire zones") where extensive indiscriminate bombing and artillery barrages were permitted. U.S. advisors from the Air Mission directed Guatemalan Air Force operations and even participated in some of them. The death in a crash by U.S. Air Force Major Bernard Westfall of the Air Mission in September 1967 while on a bombing mission in a converted T-33 jet trainer (the most common U.S. donated Guatemalan aircraft) confirmed this. Officially Westfall "died while testing the aircraft" but according to Maryknoll missionaries and Guatemalan activists, Thomas and Marjorie Melville, in Guatemala -- Another Vietnam?, "it was common knowledge and a public topic of conversation that the Major [Westfall] often tested Guatemala aircraft in strafing and bombing runs against guerrilla encampments in the northeastern territory. ${ }^{46}$

The United States set up a rotation system referred to jokingly as the "Saigon-Guatemala Shuttle." According to the U.S. State Department records and the Foreign Service Lists and Biographic Register, some twenty-eight diplomatic, AID, and 
Office of Public Safety personnel, previously stationed in Vietnam, were transferred to the U.S. Embassy in Guatemala during the $1964-1972$ period. Below is a list by year of that personnel:

\section{TABLE XVI ${ }^{47}$}

\section{STATE DEPARTMENT OFFICIALS REASSIGNED FROM SOUTH VIETNAM TO GUATEMALA $1964-1972$}

$\underline{1964}$

Newton B. Knox - ROCAP*

$\underline{1965}$

Alfred Naurucki - public safety advisor $\underline{1966}$

Robert E. Zimmerman - USIA

David Jickling - public safety advisor

\section{7}

Lucille E. Martin - admin. asst.

F. R. Worten - engineer

Dudley Burris - public safety advisor $\underline{1968}$

Richard A. Barth - auditor

Richard E. Kaegi - asst/dir. devl. operations Sara Shonk - disbursement officer

Richard D. Van Winkle - pub/safety advisor David Wright - political officer $\underline{1969}$

Russell L. Hale - deputy controller Stan W. Jorgensen - consular officer James L. Roush - public safety advisor Drayton Phillips - program evaluation officer

1970

Leo E. Crampsey - administration specialist

Gerald D. Brown - public safety advisor Nathan Rakahar - budget/acct. officer Robert E. Culberton - director AID Jack Forcey - public safety advisor $\underline{1971}$

Rudy V. Fimbres - multisector officer Norbert F. Holz - multisector officer Karl L. Mahler - deputy exec. officer

Carl M. Fisher - hwy. engr. advisor Robert R. Parker - multisector officer 1972 Raymond F. Burghardt, Jr. - political officer

*Regional Office for Central America and Panama

Six of the sixteen public safety administrators stationed in Guatemala during the counter-insurgency war period 1966-1970 had been previously assigned to the Public Safety Administration in South Vietnam. The CIA has not released records as to how many of its Guatemalan operatives previously served in Vietnam but if the strong pattern evidenced by the State Department is any indication, one can assume they were 
significant. Uruguayan journalist Eduardo Galeano, a close confidant of the guerrillas, came up with his own short list in his book, Guatemala: Pais Occupado:

\section{TABLE XVII ${ }^{48}$}

CIA Agents Transferred from Vietnam to Guatemala.

Serving in Jutiapa Military Base

Headquarters

Richard Park Guthrie

John Chapleo Beckimon

Elton Nurmi

John Mess
Serving in Izabal Military

Robert Bernestein

Arnold Blechenger

Oscar Hunt Adams

Edward Thorton Floyd

Arthur Kerr

James McNamara

Edward Suarez

Three individuals on the State Department list, Gerald D. Brown, Alfred Naurocki and Jack Forcey, served on the staff of the CIA's infamous pacification agency in Vietnam, the Civil Operations and Rural Development Support (CORDS), which helped set up the Civil Guard, strategic hamlet and Phoenix assassination programs. Human rights activists identified two public safety advisors and one political programs officer within the U.S. Embassy: Dudley Burris, Richard D. Van Winkle and David Wright as CIA agents. Several key U.S. military officers attached to Guatemala's MAAG had also served in Vietnam. They included the 1966-1967 head of the U.S. military mission, Colonel Joseph Koontz, the 1967-1968 chief advisor, Colonel John Webber, and the head of the U.S. Civic Action advisory staff during the counter-insurgency campaign of 1966-1968, Major Frederick F. Woerner, "a combat veteran of over fifty search and destroy missions in Vietnam. 149 
By the spring of 1967 the State Department judged the rural counter-insurgency war in Guatemala "a huge success." ${ }^{50}$ U.S. and Guatemalan forces completely annihilated whole units of Guatemalan rebels. Many of the rebels failed to maintain proper security and lived openly in vulnerable villages. According to the rebels own highly critical postmortem, new student recruits neglected to maintain watches or apprise their units of government military movements. The guerrillas also failed to establish a strong Indian, and peasant support base within Zacapa and Izabal. They didn't receive enough intelligence from the local population which in several cases turned against them and cooperated with the Army. ${ }^{51}$

Mostly, however, the massive fire power and mobility of the U.S. led Guatemalan forces simply overwhelmed the guerrillas. In a combined arms effort, the U.S. brought thousands of seasoned, well equipped troops against the guerrillas' rather amateurish and lightly armed 500 man force. The guerrillas also suffered a key loss of leadership. Turcios Lima died under somewhat mysterious circumstances in a automobile accident in early October 1966, just as the government offensive opened. His death decapitated the rebel movement at the very start of the campaign. The government killed or captured some four hundred out of five hundred active guerrillas in the first few months of the war, dealing a severe defeat to the rural insurgency that it would really not recover from until the mid-1970s. ${ }^{52}$

In the wake of this counter-insurgency success government allied paramilitary forces launched a reign of terror in both the cities and the countryside. They took advantage of the wartime crisis atmosphere to settle old scores with political enemies and even neutrals. Besides the PMA, the military commissioners and the Judicial 
police, a number of "private groups" came to fore in this effort. They included Movimento Anti-Communista Nacionclista Organizado or MANO BLANCO, Nueva Organizacion Anti-Communista or NOA, Consejo Anticommunista de Guatemala or CADEG, as well as numerous others, RAYO, CRAG and ASA. ${ }^{53}$ These groups, comprised of retired servicemen and policemen, reservists, landowners, businessmen and paid thugs systematically eliminated all individuals suspected of "communist leanings." They slaughtered hundreds of largely non-communist civilians -- labor organizers, peasant cooperative leaders, agrarian improvement workers, rural teachers, labor lawyers, leftist journalists, college students and professors, and just about everyone who subscribed to any political beliefs to the left of the MLN. This terror campaign effectively wiped out the few successful grass roots Alliance for Progress programs in Guatemala and reasserted the oligarchy's unchallenged rule in the countryside. Hard line paramilitary groups maintained strong links to the Guatemalan military and its U.S. advisors. In early 1967 they even began assassinating Revolutionary Party mayors, councilmen and officials -- members of the President Mendez Montenegro's own party. In the all-out counter-insurgency war of 1966-1968 and the counter-terror that followed it, 8,000 to 11,000 Guatemalan civilians lost their lives. $^{54}$

But the Johnson Administration's troubles had just begun for the Guatemalan left rocked back on its heels, counter attacked with a ferocity that matched the right wing paramilitary outrages. While the war continued smoldering in the countryside, its main focus shifted to the capital where Guatemala City, like Saigon, soon faced its own Tet Offensive. 


\section{CHAPTER V FOOTNO'TES}

1 CIA, Office of National Estimates, "Recent Arrests of Communists in Guatemala," March 5, 1966, LBJ, NSF, National Intelligence Estimates, Box 8, Folder 82: Guatemala, Jan. 1966-June 1966.

p. 12.

2 El Imparcial, July 16, 1966, p. 1, pp. 14-16, New York Times, July 18, 1966,

3 Jerry L. Weaver, "The Military Elite and Political Control in Guatemala, 1963-1966," Social Science Quarterly, Vol. 50, No. 1, (June 1969), pp. 36-43.

4 . "Bureaucracy During a Period of Social Change: Guatemala 1960-1969, Ramparts, Vol. 10, No. 9, (September 1970), pp. 56-59.

5 Edelberto Torres-Rivas, "Seven Keys to Understanding Central America," from Rift and Revolution, The Central American Imbroglio, ed. Howard J. Wiarda, (Washington, DC: American Enterprise Institute for Public Policy Research), 1984, p. 55 .

6 "The Guatemala Military", CIA National Intelligence Report, June 10, 1966, LBJ, NSF, National Intelligence Estimates, Box 8, Folder 82: Guatemala, Jan. 1966-June 1966.

7 Ibid.

8 George Black, Garrison Guatemala, (New York: Monthly Review Press, 1985), p. 52.

9 Gabriel Aguilera Peralta, "The Militarization of the Guatemala State," in Guatemala in Rebellion: A Documentary History, ed. by Jonathan Fried et al., (New York: Grove Press, 1983), pp. 114-9.

10 "Rule of Public Opinion in Latin America Political Stability," May 5, 1965, LBJL, NSF, Country File, Latin America, Box 2, Folder: Latin America, Vol. II, Jan 1965-Dec. 1965.

11 "The Guatemalan Military," CIA Intelligence Memorandum May 1968, LBJL, NSF, Country File, Guatemala, Box 54, Folder: Guatemala, Vol. 2, Cables, Jan 1966-Nov. 1968.

${ }^{12}$ Don L. Etchison, Militarism in Central America, (New York: Praeger Publishers, 1975), pp. 13-14. 
${ }^{13}$ Cesar Montes to the author Eduardo Guleano, Guatemala: Pais Ocupado, (Mexico City: Nuestro Timeo, 1968) p. 45.

${ }^{14}$ Alejandro de Corro, Guatemala: la volencia, (Morelos: Mexico, 1968), p. 183.

${ }^{15}$ McClintock, The American Connection, p. 64.

16 "Guerrilla Kidnappings and Assassinations of Leading Landowners," CIA National Intelligence Report, June 18, 1966, LBJL, NSF, National Intelligence Estimates, Box 8, Folder 82: Guatemala Jan. 1966-June 1966.

17 "The Guerrilla Threat to Guatemala," Zimmerman (USIA administrator) to Martin, Jan. 13, 1966 in which Zimmerman questioned the seriousness of the guerrilla movement, WNRC, RG 287, OPS, Box 61, Folder: Guatemala, General.

${ }^{18}$ David A. Crain, "Guatemalan Revolutionaries and Havana's Ideological Offensive of 1966-1968," Journal of Inter-American Studies, Vol. 17, No. 2, (Spring 1975), pp. 183-186.

19 Ibid, pp. 1887-8.

${ }^{20}$ "Cuban Support for the Guatemalan Guerrillas," CIA National Intelligence Report Sept. 12, 1966, LBJL, NSF, National Intelligence Estimates, Box 8, folder 83: Guatemala July 1966-Dec. 1966.

${ }^{21}$ El Imparcial, Feb. 6, 1965, pp. 1-9.

${ }^{22}$ Sayre (Deputy Assistant Secretary of State) to Bundy, June 12, 1965 , "Report on Recent Attacks on U.S. and Its Allies in Guatemala," LBJL, NSF, Country File Guatemala, Box 54, Folder: Guatemala, Vol. 1.

23 "Report on Guatemala: Assessment of Current Situation June 22, 1965, CIA National Intelligence Report, LBJL, NSF, National Intelligence Estimates, Box 8, Folder 81, Guatemala, 1965.

${ }^{24}$ Adolfo Gilly, "The Guerrilla Movement in Guatemala, Monthly Review, (May '65), 2: p. 39.

${ }^{25}$ Alfonso Yurrita, "The Crisis of the Established Order in Guatemala," from The Military and Democracy in Central America, ed. by Louis W. Goodman, (Lexington: Lexington Books, 1990), pp. 77-80.

${ }^{26}$ Mein to Rusk, Jan. 12, 1966, "Prospects for Presidential Elections in Guatemala," LBJL, NSF, Country Files, Guatemala, Box 54, Folder: Guatemala, Vol. 2, Cables Jan. 1966-Nov. 1968. 
${ }^{27}$ Rusk to Mein, Feb. 14, 1966, LBJL, NSF, Country Files, Guatemala, Box 54, Folder: Guatemala, Vol. 2, Cables Jan 1966-Nov. 1968.

${ }^{28}$ Bundy to Mein, March 5, 1966, Ibid.

${ }^{29}$ Kenneth F. Johnson, The Guatemalan Presidential Election of March 6, 1966 : an Analysis, (Washington, DC: GPO, 1968), pp. 47-8.

${ }^{30}$ George Black, Garrison Guatemala, p. 43.

${ }^{31}$ Rusk to Mein, March 10, 1966, LBJL, NSF, Country Files, Guatemala, Box 54, Folder: Guatemala, Vol. 2, Cables Jan. 1966-Nov. 1968.

${ }^{32}$ Moyers to Johnson, June 6, 1966, LBJL, NSF, Name Files, Box 7, Folder: Moyers Memoranda.

${ }^{33}$ Edelberto Torres-Rivas, "Guatemala: Crisis and Political Violence," from Latin America 1970:NACLA Report on the Americas, Vol. XIV, No. 1, (January-February 1970),pp. 51-3.

${ }^{34}$ Guillermo Garrido Toriello, Guatemala Mas de 20 anos de tracion, (Caraces: Editoriel Altereo de Caracas, 1980), pp. 114.

${ }^{35}$ Ibid, p. 115.

${ }^{36}$ Cesar D. Sereseres (diss.), pp. 68-71.

${ }^{37}$ Michael McClintock, The American Connection, pp. 84-85.

${ }^{38}$ Vincente Collazo-Davila, "The Guatemalan Insurrection," in Bard E. O'Neill et al., (editors), Insurgency in the Modern World , (Boulder: Westview Press, 1980), pp. 115-7.

${ }^{39}$ Lawrence A. Yates, "The United States and Rural Insurgency in Guatemala, 1960-1970: An INter-American 'Success Story?'" in ed. Ralph Lee Woodward, Jr., Central America: Historical Perspectives on the Contemporary Crisis, (New York: Greenwood Press, 1988), pp. 60-61.

${ }^{40}$ The Chicago Daily News, Dec. 5, 1966, pp. 3, 9.

${ }^{41}$ Donald Duncan, "The Whole Damned Thing Is a Lie," Ramparts, Vol. 8, No. 9 (Sept. 1969), pp. 43-5.

42 Ibid, Nov. 10, 1967, p. 1, 7.

${ }^{43}$ McClintock, The American Connection, p. 81.

${ }^{44}$ El Imparcial, Dec. 11, 1966, pp. 2, 7. 
${ }^{45}$ Ibid, Nov. 10, 1967, p. 1, 7.

${ }^{46}$ Thomas and Marjorie Melville, Guatemala--Another Vietnam? (London: Penguin Books, 1971), p. 291.

${ }^{47}$ Service Listings from the State Department's Foreign Service List and Biographic Register. Many of these names also cited in Susanne Jonas and David Tobis, Guatemala, (North American Congress on Latin America, 1981), p. 201.

${ }^{48}$ Galeano, Guatemala: Pais Ocupado, p. 71.

49 Michael Klare, War Without End: United States Global Repression, (New York: Alfred Kropf, 19973), pp. 97-8.

${ }^{30}$ Mann to Mein, Dec. 22, 1966, LBJL, NSF, Country Files, Box 54, Folder Guatemala Vol. 2, Cables, Jan. 1966-Nov. 1968.

51 Richard Gott, Guerrilla Movements in Latin America, (London: Nelson and Sons, 1970), pp. 78-9.

52 Lawrence Yates, "The United States and Rural Insurgency 1960-1970," p. 65.

33 "Paramilitary Groups in Guatemala," Dec. 28, 1966, CIA National Intelligence, LBJL, NSF, National Intelligence Estimates Report, Box 8, Folder 83: Guatemala July 19966-Dec. 1966.

\$4 Shelton Davis and Julie Hodsen, Witness to Political Violence in Central America, (Boston: Oxfam America, 1982), pp. 63-4. 


\section{CHAPTER VI}

\section{TET COMES TO GUATEMALA: THE URBAN GUERRILLA CRISIS $1967-1969$}

The April 1967 Office of Public Safety Incident Report sent from Guatemala City to Washington had a distinctively upbeat ring about it. It stated that April had been "a fairly good month and a considerable improvement over March." In April the report went on to say there had been " 2 riots, 5 attacks on the police, 4 attacks against police buildings, 9 attacks by guerrillas or organized bands other than on the police, 8 bombings, 7 assassinations, 5 political kidnappings and 7 reported incidents of sabotage." ${ }^{11}$ All in all, for the Guatemalan government in 1967, a fairly calm month.

The first optimistic reports of success against the rural guerrillas in late 1966 turned markedly sour by spring. Due in no small part to the wave of assassinations in the countryside by MLN allied paramilitary groups, new recruits joined the guerrillas as fast as the security forces could kill them. Left-wing retaliations increasingly spread to the cities where a fairly effective "safe house" network afforded guerrillas some refuge from the storm. A number of tactical advantages derived from taking the war to the city, chief among them the reluctance of the military to bomb its own capital. Urban warfare negated the government's overwhelming air advantage in the countryside. ${ }^{2}$

The U.S. led rural counter-insurgency campaign, besides wiping out several hundred guerrillas, also killed thousands of innocent civilians caught in the crossfire of napalm, mortar and artillery barrages, helicopter gunship raids, and heavy conventional bombing. The death toll was estimated at 4,000 , but it would more than double after this strictly military phase of the campaign ended. The Guatemalan Army and its U.S. 
advisors committed the classic counter-insurgency error warned against in its own doctrine:

Military operations by large bodies of troops, as a non-selective method of applying force are likely to inflict disproportionate hardship on the civil population; it will be compounded if the troops regard themselves as in enemy territory and behave accordingly. The result is likely to be popular bitterness which turns friendly or neutral elements against the government. Large scale operations directed against guerrillas thereby tend by their very nature to strengthen and widen the very insurgency they seek to defeat. ${ }^{3}$

With scores of villages and farms destroyed by the "pacification campaign", as in Vietnam thousands of peasants fled to the cities depopulating their traditional farmlands. These rural refugees proved fertile recruiting ground for the bomb throwers, kidnappers and assassins of the left. They also supplied additional murder victims for the hit squads of the right.

While the rebels may have suffered severe setbacks in the countryside, like the Viet Cong and North Vietnamese in the winter of 1967-1968, they hoped to rebound politically by taking the war to the cities and striking at the very bowels of the security apparatus built to destroy them. Although the Guatemalan left's tactics at times proved as inflammatory, vicious and inhumane as the government's it is important to note that the government launched the opening blows in this new "dirty war" phase of the counter-insurgency and inflicted atrocities at a rate that can best be estimated at about five to one in comparison to the left. ${ }^{4}$ The left's sporadic attacks tended towards emotional response. The right's terror campaign proved much more systematic.

As early as June 1966 a full month before Mendez Montenegro's government took office, the first ominous, unsigned leaflets appeared in Guatemala City proclaiming the creation of anti-Communist "defense squads." Some seventeen paramilitary groups 
eventually sprang to life in the $1966-1967$ period, many of them clearly fictitious nomenclatures for Guatemalan military and police units. While several of these paramilitary groups may have been independently formed, they all maintained close ties to the Guatemalan military and police as well as the National Liberation Movement (MLN), Guatemala's leading right-wing party and President Mendez Montenegro's chief political opponents. $^{5}$

The MLN 's leader Mario Sandoval Alarcon pulled no punches in spelling out his party's philosophy. "I am a Fascist and I have always tried to model my party after the Spanish Falange." ${ }^{\text {B }}$ Besides the larger, more infamous, terror groups such as MANO BLANCO, NOA, CADEG, RAYO, ASA, a number of smaller groups surfaced, sporting more flamboyant names: Ojo per Ojo (Eye for an Eye), Rosa Purpura (Purple Rose) and El Buitre Justiciero (The Hawk of Justice). In the 1970s many of these groups took on religious connotations -- the Assassins of the Virgin Mary, the Army of St. John the Baptist, etc., but in the 1960 s most remained strictly political ${ }^{7}$ The MLN and much of the oligarchy supported these groups quite openly. Wealthy businessman Raul Garcia Granados told the Guatemalan daily La Hora:

Of course, the death squads are organized under the patronage and approval of the government and the Army. They have lists of people that are suspected of being communists and they kill them. It's war, you see, a war between communists and anti-Communists. They have the sympathy of most of the Guatemalan people. ${ }^{8}$

U.S. investors seconded Granados' opinion. Bank of America manager Keith Parker said:

When you've got a situation like you have here you need the strongest government you can get. If you use human rights in a country with guerrillas you're not going to get anywhere... What they do here is declare martial law. 
Then when you catch somebody, they go to a military court. Three colonels are sitting there; you're guilty, you're shot. It works very well. ${ }^{9}$

This philosophy contradicted the official, prosaic anti-guerrilla rules laid out by the Defense Department and Embassy MAAG that included such homilies as:

1. Pay the market price in cash for anything obtained locally.

2. Return anything you borrow.

3. Pay for everything you break.

4. Never walk on or needlessly damage growing crops.

5. Leave people's women along.

6. Be courteous and polite to people and help them when you can.

7. Use a minimum of violence and only as a last resort in selective situations. ${ }^{10}$

The president of the American Chamber of Commerce in Guatemala, Fred

Sherwood, took a more pragmatic view:

Why should we do anything about the death squads? They're bumping off the commies, our enemies. I'd give them more power. Hell, I'd give them more cartridges if I could, and every one else would, too. They're bumping off our enemies, which are also the enemies of the United States. Why should we criticize them? ${ }^{11}$

Sherwood had a point. U.S. counter-insurgency doctrine included "the selective use of counter-terror through paramilitary forces." ${ }^{12}$ This philosophy comprised the psychological part of the counter-insurgency equation. Friendly governments supposedly had the legitimate right to retaliate in kind against communist terror directed against them As Naval Intelligence officer, Albert L. Fisher, wrote in "To Beat the Guerrillas at Their Own Game," in Military Review:

This is the tactic of intimidating, kidnapping or assassinating carefully selected members of the opposition in a manner that will reap the maximum psychological benefit for friendly forces. ${ }^{13}$

This type of doctrine had been taught for years to Guatemalan officer candidates at the U.S. Army School of the Americas and dozens of other U.S. facilities around the 
world. Therefore when the United States expressed alarm at escalating paramilitary violence in Guatemala, its criticisms should be judged more as protest against the amount and not the type of violence employed.

The MLN took out full page advertisements as early as August 26, 1966, in Guatemala's most popular newspaper El Imparcial which warned of the impending "vigilante action...the MLN cannot prevent the people from acting in self-defense. The government should not , be surprised that the citizenry organize themselves for self-defense or take justice into their own hands." ${ }^{14}$ On May 7, 1967, just as the counter-terror gathered momentum, another advertisement, this time in La Hora read:

The government, the people and the Army have amalgamated into a single fighting force with the object of destroying the guerrillas definitively in a political and armed struggle without quarter which will be a true national crusade! ${ }^{15}$

The MLN mounted a concerted effort both in the cities and the countryside to whip up a popular frenzy for its new vengeance campaign. It bussed urban supporters to rural demonstrations where they waved placards reading: "Death to the Guerrillas!" "Long Live the Army!" "We Don't Want to Be Another Cuba!" "Guerrillas, Stop Killing Innocent People!" The U.S. Embassy drove American journalists to these staged events where they reported "mass peasant support for the counter-insurgency campaign in Zacapa and Izabal." ${ }^{16}$

Paramilitary groups next distributed death list pamphlets throughout the cities with names and pictures of "Traitors to the Guatemalan Nation." In rural areas Guatemalan Air Force planes dropped these leaflets. "Your Hour Has Come, 
Communists at the Service of Fidel Castro, Russia and Communist China." They read: "You have until the last day of March to leave the country."17

MANO BLANCO enthusiasts stencil painted hundreds of white hands on the doorways of union leaders, leftist journalists, activist priests, labor lawyers, even largely moderate politicians who had once suggested negotiations with the guerrillas.

The paramilitary squads placed the mutilated bodies of their first victims in prominent areas: in city market squares, on the steps of churches or in victims' doorways. They pinned notes to the bodies which explicitly described: "how the victim had been slowly cut to pieces, castrated, strangled, burned, drowned or smothered."18 Often pieces of bodies were simply strewn about city streets, leaving it to relatives to piece them together and try and discover who was who. Hundreds of victims simply disappeared never to be heard of again, ten years before the desseperados of Argentina became a cause celebre. ${ }^{19}$ The U.S. Army's 1962 field manual Operations Against Irregular Forces, the virtual bible at the U.S. School of the Americas in the early 1960s, included the following list of overt irregular activities that could be used to confront communist insurgents and their supporters:

terrorism by assassination, bombing arson, torture, mutilation and kidnapping, provocation of incidents, reprisals, and holding of hostages, the use of chemical or biological agents, the use of booby traps and explosive devices.

Covert irregular activities included:

espionage, sabotage, dissemination of propaganda and rumors, issuing of false or misleading reports, assassination, extortion, blackmail, identifying individuals for terroristic attack, psychological destruction of individuals. ${ }^{20}$

Lyndon Johnson may have been referring to more than just the CIA assassination attempts on Castro when he exclaimed in 1964: "We have been operating 
a damned Murder Incorporated in the Caribbean!"21 In his 1984 work, Garrison Guatemala, George Black investigated U.S. complicity with violent paramilitary organizations. Black demonstrates how the Guatemalan military and elites, long accustomed to hostility against the Indians and upstart ladino reformers, felt more at ease with the United States anti-communist crusade than with their own country's nationalist aspirations. This attitude embodied a classic colonial elite mentality, emphasized in much of Franz Fanon's ground breaking work, and is clearly rooted in the 300 year old Spanish colonial experience. Like many revisionist studies published in the early 1980 s at the height of the Reagan backed contra war in Nicaragua and the bloody civil war in El Salvador, Garrison Guatemala contains a fair amount of presentism and sometimes reaches, in trying to present parallels between the 1960 s and the 1980 s. Black does an effective job, however, in portraying counter-revolution as a way of life for successive Guatemalan governments ever since the 1954 U.S. backed coup.

By the fall of 1967 the activities of right-wing assassination squads reached pandemic proportions. Every week scores of twisted bodies, many those of outstanding and educated ladinos were discovered in rivers, lakes, municipal dumps and alleyways. At the funeral of academic and labor lawyer, Julio Carey Herriera, the rector of the University of San Carlos expressed the frustration of those trying to reform the political system:

The black banner that preaches the death of intelligence has been raised many times...It seems that the blood of the university is being demanded as the solution to the problems of Guatemala. It seems that giving bands of killers a license to operate is seen as the solution to our problems. ${ }^{22}$ 
Earlier in the year, Walt Rostow, Chairman of the State Department Planning Council and a longtime counter-insurgency enthusiast, praised "the aggressiveness of the security forces in Guatemala" which resulted in "the death or capture of several key members of the guerrilla and urban terrorist apparatus...The security forces should be congratulated for conducting an outstanding counter-terrorism campaign against the Communists. ${ }^{123}$ Rostow failed in any way to either mention or criticize the incredible amount of atrocities and bloodletting associated with this effort. He also totally ignored the concerns of the duly elected Revolutionary Party (PR) whose Congressional representative Edmundo Lopez Duran spoke out in the Congress in February 1967: "The situation of the state of siege has been taken advantage of by the terrorist organization MANO BLANCO and by the military commissioners to persecute and kill well known members of the Partido Revolucionario. ${ }^{124}$ The next day MANO BLANCO put Lopez on its death list. (They murdered him in January 1968.)

By October 1967, however, the State Department Director of Intelligence and Research, Thomas Hughes sent an urgent memorandum to Dean Rusk:

President Mendez Montenegro evidently gave the security forces a carte blanche in the field of internal security in exchange for military support to his administration. The United States supported this arrangement. He and we may now wish to reconsider, however, as the military use of extra-legal tactics is creating considerable unease in Guatemala and threatens to undermine the President's popular support. The Embassy warns that continued use of such rough and ready counter-insurgency tactics could lead to popular agitation for the re-establishment of law and order, and eventually might create conditions propitious for a coup...At the center of the Army's clandestine counter-terrorist apparatus is the Special Commando Unit formed in January 1967 by CIA advisors and currently under the command of Colonel Maximo Zepeda. Composed of both military and civilian personnel, the Special Unit has carried out abductions, bombings, street assassinations and execution of real or alleged communist and occasionally has also acted against other vaguely, defined "enemies of the government." The Special Unit supposedly does not act without specific orders from Colonel Zepeda who in turn receives his 
instructions from the Defense Minister, Colonel Arriaga Bosque..For a time the Special Unit also worked with the leaders of the notorious MANO BLANCO...rough estimates indicate that approximately 500-600 persons have been killed by the unit since January; with the addition of missing persons this figure might double to $1,000-1,200$.

This remarkable document (one of the few declassified and completely unsanitized reports of the period) went on to describe the full breadth of the Guatemalan terror network as well as the depth of U.S. complicity:

Civilian counter-insurgency groups armed and organized by the military are also active in rural Guatemala -- particularly under the jurisdiction of Colonel Carlos Arana, commander of the Zacapa Military Brigade...The Army says it has approximately 1800 armed civilians under its control but other armed groups are known to be operating semi-independently. These groups have long been a source of concern to rural members of President Mendez's Revolutionary Party (PR) who have complained of persecution and who fear that reported rightist/military plans to expand these groups are motivated by partisan political considerations...The entire situation brings into serious question the ability of President Mendez, the government or even the Minister of Defense to control the activities of the counter-insurgents...We find persuasive the Embassy speculation that "in some instances the government can still exercise a degree of control over the activities of the clandestine killer units, both civilian and military" but that it would "be foolhardy to count on it." Mendez may shortly discover, if he has not already done so, that survival can have too high a price. ${ }^{25}$

The crowning irony of this conclusion was that the United States helped push Mendez Montenegro into making his agreement with the military in the first place. But now that right-wing terror, which Washington helped sponsor, began to spin out of control, the State Department blamed Mendez Montenegro for failing to bridle his military.

What the Guatemalan military at the behest of the United States government actually conducted in Guatemala was a Central American version of the highly controversial Vietnam Phoenix Program Begun also in 1967 by CIA assistant director, William Colby, the Phoenix program embodied an abandonment of the original 
integrated rural program of Robert Komer's in Vietnam, the so-called "strategic hamlet concept", in favor of a complete liquidation of the Viet Cong infrastructure. As ex-CIA agent, Frank Snepp, put it: "Instead of winning their hearts and minds the idea behind Phoenix was to just kill the bastards. ${ }^{126}$ By 1971, the Phoenix program had eliminated 20,687 supposed members of the VC resistance network. (The South Vietnamese government cited a figure of $40,994.)^{27}$ This program, like its smaller version in Guatemala, encompassed the use of specialized "CT" counter-terrorism units comprised of CIA, U.S. Special Forces and indigenous South Vietnamese paramilitary personnel, the so called Provincial Reconnaissance Units (PRUs) to identify and assassinate anyone remotely connected to the Viet Cong. Besides VC operatives the victims included Buddhists, students, opposition politicians and civilian critics of the Saigon regime -even personal enemies and creditors of the assassins. ${ }^{28}$ The program called for the use of murder, ambushes, kidnappings, torture and intimidation against VC leadership, the same "fight fire with fire" rationale employed by right-wing terrorist groups in Guatemala.

Political violence in Guatemala reached a crescendo in early January, 1968, when members of MANO BLANCO dumped the raped, mutilated and tortured body of popular 26-year old Rogelia Cruz Martinez, the former "Miss Guatemala of 1959" onto a main thoroughfare in the capital. Martinez came from an upper middle class family, professed leftist sympathies and was reportedly the girlfriend of rebel guerrilla Leonard Castillo Johnson. ${ }^{29}$ On January 16,1968 , before the outcry over this atrocity died down, masked FAR machine gunners, firing from a passing green sedan, sprayed a Ford van full of U.S. military advisors about ten blocks from the U.S. Embassy. They 
succeeded in killing the chief of the U.S. military mission, Colonel John D. Webber, and the Naval Attaché, Lieutenant Commander Ernest A. Munro, as well as wounding two other U.S. servicemen. ${ }^{30}$ The FAR issued a statement claiming the attack represented an act of vengeance against "the master minds of the genocidal forces that had murdered 4,000 Guatemalans in the past year."31

A January 26, 1968 Time Magazine article reported that "Webber and Munro were victims of their own success in Guatemala." The article went on to praise the energetic Webber for reinvigorating the Guatemalan counter-insurgency effort by procuring "U.S. jeeps, trucks, armored cars and helicopters to give the army more firepower." When the reporter questioned Webber's policy of arming "civilian collaborators to kill peasants who they considered guerrillas or potential guerrillas," Webber replied: "That's the way this country is. The Communists are using everything they have including terror. It must be met." ${ }^{132}$

In his statement Webber conformed to the widely held misconception proclaimed in virtually every official document of the period that terror lay at the base of the Guatemalan guerrillas' civilian support. This constantly repeated "mantra" appeared as an almost desperate attempt to explain away the apparent cooperation of large segments of the population with the Revolutionary guerrillas. Washington's counter-insurgency dogma remained adamant in its belief that peasants were coerced into compliance with the Communists. Why else would they join them? The Vietnam experience is replete with similar delusions. Since the counter-insurgency experts mistakenly held terror as the key communist technique, it naturally followed that counter-terror framed the appropriate military response. Yet with the exception of a 
limited number of executions of government informants and notoriously brutal landlords, the Guatemalan guerrillas practiced very little terrorism against civilians in the countryside. In fact, they went out of their way, unlike the U.S. trained Guatemalan counter-insurgency units, to befriend the population. "Without the people we are nothing," FAR leader Cesar Montes said. "We have men who work with us by night and work the soil by day. We build the people's organization for revolutionary war. Land to him who works it is our slogan. ${ }^{133}$ Eduardo Galeano, a Marxist Uraguyan journalist, spent several months in 1966-67 in the mountains of Zacapa, interviewing the guerrillas. His 1968 Guatemala: Pais Occupado is an important representation of the radical Latin American view of U.S.-Guatemalan relations. Published at the height of the Vietnam War, his work captures much of the romanticism, the tragedy, and the violent anti-Americanism of the period. Imperialism is Galeano's favorite word and he manages to work it into practically every other sentence. His view of Guatemala and most of Latin America as a colony of the United States is an important one, however, so prevalent among the Latin American Left in the 1960s and 1970s. Galeano is a kind of forerunner of the later "dependency school" of economists and other social scientists, such as Andre Gunder Frank, who maintain that the only thing the United States ever developed in Latin America was underdevelopment. This school strongly influenced later revisionist historians such as Walter LaFeber and Richard Immermann.

The decapitation of the U.S. military mission in Guatemala in January 1968 sparked increased waves of atrocities. Right wing gunmen cut down liberal Congressmen at home over their breakfast tables. Police captains were assassinated 
leaving church. One labor leader ran into a police station to escape a carload of MANO BLANCO gunmen. The police shot him in the lobby. Bleeding profusely he begged for his life. Laughing, the police carried him up to the fourth story roof and threw him off $^{34}$ He thus joined the list of "leftist suicides" which one U.S. embassy official surmised "may be a result of the growing disillusionment with communist ideology. ${ }^{135}$

By the spring of 1968 the collapse of Mendez Montenegro's government appeared imminent: It could not control Guatemalan Army directed terrorism or the retaliations and bombings of the left. In an example of both Mendez Montenegro's growing impotence and personal decency, the National Palace was full of his friends and former students sleeping on cots and sofas. Once he learned acquaintances were on the "death lists" the president invited them to live with him in the palace, the only place in Guatemala where political activists were safe. ${ }^{36}$ Moderate elements even those that originally supported MLN paramilitary attacks on communist civilians and blatant leftists felt the campaign had gone too far. Washington's confidence in Mendez Montenegro reached a new low after the assassination of its military mission and increasing rumors of military plots against him. Hard right officers, aligned with the MLN, resented the president's efforts to restrain their paramilitary campaign and plotted against him.

On March 16, 1968 the Guatemalan right, delirious with recent success, overplayed its hand. Three key security force officers, Colonel Francisco Arana, leader of the Zacapa counter-insurgency war and of the paramilitary terror in the countryside; Colonel Manuel Francisco Sosa Avila, the Director of the National Police and coordinator of the right-wing urban death squads; and Colonel Rafael Arriaga Bosque, 
the Minister of Defense and "godfather" of the Guatemalan terror network conspired to overthrow Mendez Montenegro. They hatched a plan for kidnapping Guatemala's Roman Catholic Archbishop Mario Caseriego and blaming it on the Rebel Armed Forces (FAR). The Archbishop was a well known conservative and vociferous critic of the guerrillas. He blessed U.S. donated police cars and armored personnel carriers with holy water at ceremonies in the capital. In an interview he unabashedly admitted, "I love military life. I love it when it is based upon discipline such as I believe is the case in our army and the American army. ${ }^{137}$ The military conspirators felt that the abduction of such a man would naturally be blamed on the guerrillas. They hoped it would provoke massive anti-government demonstrations. They could then seize power to restore order. Of the three, Colonel Arana had the strongest presidential ambitions. After taking control of the government the three colonels planned to arrange for the release of the Archbishop following a period of sham negotiations with his "leftist captors" from which they would emerge as even greater heroes for delivering the archbishop to safety. ${ }^{38}$

Their plan backfired mainly because of poor execution and the unwillingness of the archbishop to go along with this bizarre scheme, this auto-secuestro or self-kidnapping. The abductors picked up the archbishop within 100 yards of the heavily guarded National Palace in the presence of scores of heavily armed troops and police. Guatemalan journalists working for El Imparcial and La Hora immediately suspected military collusion. ${ }^{39}$

Rumors of security force involvement led to anti-military, not anti-government, demonstrations as the plotters had hoped. By March 20, the second day of the crisis, a 
U.S. Embassy telegram to the State Department decided "the kidnapping of the archbishop is part of a military/rightist plot to overthrow the government. Kidnapping of the archbishop seems to have been carried out by members of the armed forces to promote public demonstrations. ${ }^{140}$

In a comedy of errors a Guatemalan civilian, a postal clerk, spotted the archbishop in the company of the paramilitary kidnappers. The civilian followed them in his car to a safe house in Villa Candes where the bishop was held. The postal clerk called the National Police to report the kidnappers whereabouts. Within minutes of his call the bishop and his entourage suddenly left the townhouse confirming to the clerk that the police were in on the deal. He phoned the newspapers minutes before he himself was arrested by the police "for spreading malicious rumors detrimental to the security of the state. ${ }^{41}$ The CIA meanwhile got wind of this story and through their own confidential police and military contacts, quickly confirmed the military's involvement.

Their scheme uncovered, the conspirators searched desperately for scapegoats. On the same day that the archbishop was released unharmed, the National Police arrested two MANO BLANCO operatives involved in the kidnapping, Raul Estuardo Lorenzana and Ines Mufio Padilla. While in transit to a courthouse, the patrol car holding the two men stopped and the arresting officers abandoned it. A few seconds later another car pulled up alongside the patrol car and fired approximately 200 machine gun bullets into it, shredding the two hand-cuffed prisoners. ${ }^{42}$

If the plotters hoped this act would exonerate them, they were mistaken. The whole sordid incident generated widespread public outrage against the security forces, a rare occurrence in Guatemala in the 1960s. Seizing upon this propitious turn of events, 
President Mendez Montenegro reasserted himself and demanded the resignation of all three conspirators. ${ }^{43}$

The military surprisingly acquiesced. Several senior officers, including the retired yet influential Colonel Peralta, felt that military discipline and control had collapsed badly amid the "wild west" tactics of the past year. While Colonel Arana remained extremely popular among his own crack counter-insurgency troops, significant sectors. of the officer corps -- the more moderate technocratic and administrative branch -- regarded him as a dangerous opportunist. The government in the end brought no charges against the three men such was the institutional power of the military in protecting its own. Instead the conspirators were quietly given foreign assignments. The government sent Defense Minister Bosque to Miami, Florida, to become Counsel General, National Police Chief Avila to Spain as Military Attaché, and "The Butcher of Zacapa" (his own men called him the "Tiger of Zacapa"), Colonel Arana, to Nicaragua as ambassador, where Dictator Anastasio Somoza feted him as a hero. ${ }^{44}$

Briefly the right-wing terror abated. In late August, however, on a tip from an informant, the government captured FAR leader Camilo Sanchez. The rebels demanded his release and began a series of savage reprisals against government officials which culminated in the August 28, 1968, assassination of U.S. Ambassador John Gordon Mein, the first American ambassador ever to be killed in service in history. The rebels apparently meant to kidnap and exchange Mein for Sanchez, but the ambassador ran from the gunmen after they forced his car off the road. They shot and killed him. ${ }^{43}$ 
The government declared a state of siege. What little control President Mendez Montenegro had managed to reimpose over his military and right wing terrorists due to the archbishop fiasco, ended. The resurgent security forces unleashed a new series of attacks occasionally matched by FAR atrocities. A Tet-like atmosphere descended over Guatemala City particularly around the U.S. embassy compound. Machine gunned, bombed, its ambassador slain, its military mission slaughtered, the facility took on wartime siege mentality strongly reminiscent of Saigon during the horrific attacks of January and February 1968, when Viet Cong sappers penetrated the compound and nearly killed Ambassador Ellsworth Bunker. Cables from the State Department warned all embassy personnel to take the strictest security precautions when traveling to and from the embassy. Washington ordered a doubling of the Marine guard contingent. Guatemalan armored cars ringed all access roads. ${ }^{46}$

In Washington 1968 proved a turning point in the Cold War. Johnson virtually admitted defeat in Vietnam with his decision not to run again. The policy of containment that had shaped U.S. foreign policy from Truman, Kennan, Acheson, Dulles and Kennedy seemed at least temporarily bankrupt. The United States' global economic dominance, the engine of its military and political power, also appeared to be slipping. But while a reappraisal of Washington's relationship with the Soviets and the world might be taking place in the late 1960s and early 1970s, the hard line in Latin America only intensified. It was one thing to admit failure eight thousand miles away in Asia; it was quite another to countenance defeat in one's own backyard. U.S. fairly direct intervention in Guatemala on two occasions in 1954 and 1966 predated by two years similar Soviet interventions within its own sphere of influence in Hungary in 1956 
and Czechoslovakia in 1968. While Washington might write off Vietnam as an exotic military adventure gone awry, it regarded communist subversion in Guatemala as an almost internal domestic revolt the same way Khrushchev and Brezhnev viewed their respective Warsaw Pact rebellions. In siege warfare, dissension inside the fort in often more threatening than the larger battle on the ramparts.

The New York Times called Mein's murder a "foul cowardly act." ${ }^{147}$ Missing in its coverage was any mention of Mein's complicity in the relatively enormous U.S. military build-up of Guatemalan security forces during his tenure or of Mein's enthusiastic support for the "paramilitary solution" in Guatemala. One of the reasons Washington assigned the 52 year old Mein to Guatemala in 1966 was because of his counter-insurgency experience in Greece during the late 1940s when he was the political officer at the U.S. embassy in Athens. ${ }^{48}$ (John Peurifoy, the U.S. ambassador during the 1954 coup, had held a similar position in Greece.)

In 1978, ten years after the assassination, a MANO BLANCO operative, Jorge Zimeri Saffie alleged to the New York Times that right-wing Guatemalan military officers participated in the murder of Mein. Their influence badly diminished by the archbishop kidnapping farce, they hoped to regain the upperhand by committing this outrage which would automatically be blamed on the left. Counter-insurgency doctrine listed staged atrocities as "an often very effective technique for discrediting opposition forces." Guatemalan paramilitary units were famous for bombing government buildings as a prelude to vicious political crackdowns. Michele Firk, a French socialist who reportedly rented the car used to assassinate Mein, "committed suicide" before the 
police could bring her to court. She shot herself, which even the CIA report on the incident noted "was an uncharacteristic method of suicide for a woman." ${ }^{49}$

No conclusive proof has ever surfaced of military or right-wing involvement in the assassination of Mein. Zimeri, arrested in Miami for illegal arms sales, when the New York Times interviewed him, may have simply concocted the story to escape prosecution or extradition to Guatemala. Yet the continued Machavellian tactics of the Guatemalan right throughout this period leave the charge open to question.

Spurred on by the assassination, the ever growing cycle of political violence continued throughout 1968 and into 1969. President Mendez Montenegro barely hung on as a sort of figurehead leader. The CIA chronicled the main deleterious effects of this new Tet offensive and counter-offensive in Guatemala: "The fact that real power in Guatemala resides with strictly violent conservative elements means that any government -- and especially the suspect incumbent one -- flirts with political disaster in pushing for even the most elemental progress and reform. ${ }^{150}$ Just as the "winning the hearts and minds" campaigns in Vietnam, the seven year attempt at "nation building" in Southeast Asia -- collapsed irrevocably in the January-February 1968 bloodbath, so similar hopes of the Alliance for Progress in Guatemala died in a hail of machine gun fire along rural trails and city back alleys in the late 1960s. The savage "scorched earth" counter-insurgency campaign in Zacapa and Izabal destroyed overnight the decade long efforts of Peace Corp Volunteers, Maryknoll missionaries and AID local project workers to build peasant cooperatives and credit unions, dig wells, improve irrigation, open schools and clinics. The chilling effect of the right-wing terror spread far beyond the actual areas of the counter-insurgency. "Everyone was terrified," one Peace Corp 
volunteer, James McNeill, testified. "Peasants and Indians ran from anyone connected with the government. Two years of work went down the drain in my district. We had the materials but the campesinos were afraid to build their own school...[for fear of the] landowners retaliation. ${ }^{51}$

In Guatemala City the AFL-CIO recruitment drive effectively ended when rightists bombed their headquarters in 1967. "You would have to have a death wish to want to become a labor ,organizer in Guatemala in the late 1960s," AFL-CIO local coordinator, Emiliano Zebadua, recalled years later. $^{52}$ In 1968 AD canceled its sponsorship of a large scholarship program at the University of San Carlos. It seemed a wasted effort since most of the graduates were either murdered or became guerrillas. ${ }^{53}$

John Breen, ADD director in Guatemala, concurred with this generally pessimistic outlook in an October 2, 1968 memorandum:

My personal view is that this country is not going to achieve political and economic stability and democratic government is not going to survive, if government is essentially an absent figure throughout most of the country leaving the work of protecting lives and punishing offenders to private armies, armed crackpots, or burgeoning military caesars making a reputation in the countryside prior to their triumphant entry into Guatemala City. ${ }^{54}$

What Breen chose to ignore was his own agency's Office of Public Safety division's contribution to this process. As part of U.S. policy it effectively armed and trained the private armies and crackpots.

From the late 1960s onward, AID increased its emphasis on the larger scale development projects which benefited the wealthy and the Guatemalan military that had grown into an economic powerhouse of its own. Hopes for rural development, small business entrepreneurship and land reform ended with the Mendez Montenegro 
Administration. For the next 19 years, from 1970 to 1989 Guatemala's presidents would all be generals. As three successive Chairmen of the Joint Chiefs of Staff, Generals Matthew Ridgeway, John Gavin and Maxwell Taylor all came from the U.S. Army paratroop elite, so the successive presidents of Guatemala all emerged from the counter-insurgency units of the Guatemalan Army -- the "Kaibiles" or Tigers.

Ironically, Sir Robert Thompson, the counter-insurgency guru of both the Kennedy and Nixon Administrations, warned against the development of extra legal overkill which helped destroy the Alliance for Progress in Guatemala:

There is a strong temptation in dealing both with terrorists and with guerrilla action for government forces to act outside the law, the excuses being that the processes of law are too cumbersome, that normal safeguards in the law for the individual are not designed for an insurgency, and that a terrorist deserves to be treated as an outlaw anyway. Not only is this morally wrong, but, over a period, it will create more practical difficulties for a government than it solves. A government which does not act in accordance with the law forfeits its right to be called a government and cannot expect its people to obey the law. ${ }^{55}$

Thompson's argument fell on deaf ears in Guatemala. The policy of endless militarization and polarization grinded on. In 1968 Blase Bonpane, an outlawed Maryknoll priest, wrote: "Guatemala smells like South Vietnam in the early 1960s. There are the same United States military advisors by the hundreds, the same corrupt power structure, the same fear of communism to the point of paranoia, the same heaps of dismembered peasants by the sides of the roads..."156

In early 1970 the newly promoted General Francisco Arana Osario, kidnapper of Archbishop Casariego, the "Butcher of Zacapa", returned to Guatemala in triumph to run for the presidency. He was elected a few months later in an election noted for "major voter discrepancies" and "massive intimidation at the polls". In an interview 
before his inaugural address he promised "to kill every last communist in Guatemala even if I have to turn the whole country into a graveyard. ${ }^{157}$ Arana, long a favorite of the U.S. Military Mission, would prove as good as his word.

In the 1966-1969 paramilitary terror campaign, the United States' counter-insurgency doctrine in Guatemala reached its apogee. The entire debacle was the logical outgrowth of the nearly decade long policy which began in the United States School of the Americas, the Inter American Police Academy, and Special Warfare School at Fort Bragg in the early Kennedy years. In fact, the roots of this tragedy could be traced back as far as the immediate post 1954 coup's counter-revolution, when at CIA and FBI direction Castillo Armas' newly established Liberacion government rutblessly purged the Guatemalan left and center, murdering and imprisoning thousands of Arbenz supporters. MANO BLANCO operatives frequently drew upon the 1955 70,000 name "black list" compiled by the CIA, FBI, and Guatemalan security agencies for their 1966-1969 victims. Many of these Guatemalan leftists and centrists, after fleeing their country in 1954, had returned during the relatively "moderate" reign of Ydigoras (1958-1963) or the early days of the Mendez Montenegro government, only to be caught up in the sudden counter-insurgency slaughter of 1966-1969. This brutal policy of political massacre forever dashed whatever slight hope of political reconciliation and consensus might have still existed in Guatmalan society in the early 1960 s.

The horrific legacy of this Guatemalan Tet continued into the 1970s and 1980s. To this day Guatemala remains one of the most politically polarized nations on the face of the earth, where bullets not ballots are the principle means of discourse, where 
torture, castration and the gasoline torching of political opponnts is more the norm than the exception. Sometimes a military laboratory can become almost too diabolical, a kind of eternal Stalingrad where Nazis and Communists fight everyday to the last man, such is the political climate of Guatemala, fostered by deep social, racial, cultural, and economic divisions yet fought with hardware, doctrine, and ideology largely exported by the United States.

Washington's attempts to try and pull back from this policy in 1968, when faced with the full magnitude and logical consequences of its own actions, proved too little and far too late. If anything, the bitter stalemate in Vietnam steeled the Johnson Administration's resolve to gain a clear victory over communist insurgents, not only in Guatemala, but in various other Latin American countries during the 1960s -- no matter what the long term costs. While the Nixon Administration would re-examine containment in both Europe and Asia with its policy of detente with the Soviets and its opening to China, the policy of ruthless anti-communism continued unabated in Central America until the 1990s. 


\section{CHAPTER VI FOOTNOTES}

1 Office of Public Safety Monthly Report for April 1967, WNRC, OPS, Box 67, Folder: Guatemala Monthly Reports, Jan. 1966-Dec. 1968.

2 Beatrice Manz, Refugees of a Hidden War: The Aftermath of Counter-insurgency, (new York: Univ. of New York Press, 1988), pp. 29-30.

3 "Counter-guerrilla Operations, Policy Planning Council," March 20, 1961, JFKL, NST, DOD Meetings and Memoranda, Box 276, Folder: Counter-insurgency Training and Techniques.

4 Figures like these are difficult to estimate but are nonetheless cited in Timothy P. Wickham Crowley "Winners, Losers and Also-Rans: Towards a Comparative Sociology of Latin American Guerrilla Movements" in Susan Eckstein (editor) Power and Popular Protest in Latin America, (Berkeley Univ. of California Press, 1988), pp. 137-8; and in Robert M. Carmack Harvest of Violence, (Norman Univ. of Oklahoma Press, 1988), p. 113.

5 Jim Handy, Gift of the Devil: A History of Guatemala, (Boston: South End Press, 1984), p. 162.

${ }^{6}$ El Imparcial, March 1, 1966, pp. 1, 7.

7 George Black, "Central America: Crisis in the Backyard," New Left Review, No. 135 (September-October 1982), pp. 20-2.

8 La Hora, March 10, 1967, pp. 3, 8.

9 Keith Parker to the author, Allan Nairn, "Bank of America Asked to Explain its Support for the Guatemalan Death Squads", Multinational Monitor, March 1972, p. 14.

10 "Troop Training and Behavior," March 10, 1961, JFKL, NSF, DOD, JCS, Vol 1, Box 276, Folder: Military Action for Latin America.

11 Fred Sherwood to the author, Allan Nairn, "To Defend Our Way of Life: An Interview with a U.S. Businessman," in Jonathan L. Fried (ed.), Guatemala in Rebellion: A Documentary History, (New York: Grove Press, 1983), p. 90.

12 "Counter-guerrilla Operations, Policy Planning Council," March 20, 1961, JFKL, NST, DOD Meetings and Memoranda, Box 276, Folder: Counter-insurgency Training and Techniques. 
${ }^{13}$ Albert L. Fisher, "To Beat the Guerrillas at Their Own Game," Military Review, Vol. XIX, No. 5, (Dec. 1963), pp. 82.

14 El Imparcial, August 26, 1966, p. 14.

15 La Hora, May 7, 1966, p. 10.

16 New York Times, March 3, 1967, p. 21.

17 Gabriel Aguilera, "The Process of Terror in Guatemala," in Central America: A Contemporary Crisis, LARU Studies, Vol. V, No. 1, September 1982, p. 13.

18 Ibid, p. 19.

19 Ibid, p. 20.

${ }^{20}$ Michael McClintock, Instruments of Statecraft: U.S. Guerrilla Warfare, Counter-insurgency and Counter-Terrorism, (New York: Pantheon Books, 1992), p. $=236$.

${ }^{21}$ Ibid, p. 205.

22 Gabriel Aguilera, "Terror and Violence as Weapons of Counter-insurgency in Guatemala," Latin American Perspectives, Spring-Summer, 1980), p. 106.

${ }^{23}$ Rostow to Johnson, "Appraisal of the Guatemalan Security Situation," May 26, 1967, LBJL, NSF, Country File, Guatemala, Box 54, Folder: Guatemala, Volz, Memoranda and Miscellaneous.

${ }^{24}$ El Imparcial, February 1, 1967, p. 1.

${ }^{25}$ Hughes to Rusk, "Counter-insurgency Running Wild," Oct. 23, 1967, LBJL, NSF, Country Files, Guatemala, Box 54, Folder: Guatemala, Vol 2, Cables, Jan. 1967-Dec. 1967.

${ }^{26}$ William Blum, The CIA: A Forgotten Documentary History, (London: Zed Books, 1986), pp. 144-145.

${ }^{27}$ Ibid, p. 146.

${ }^{28}$ Douglas Blaufarb, The Counter-insurgency Era: U.S. Doctrine and Performance, 1950 to the Present, (New York: Free Press, 19798), p. 143.

${ }^{29}$ Susanne Jonas, The Battle for Guatemala: Rebels, Death Squads and U.S. Power, (Boulder: Westview Press, 1991), p. 63. 
${ }^{30}$ Rostow to Johnson, "Assassination of Guatemala's MAAG Commander," Jan. 16, 1968, LBJL, NSF, Country Files, Guatemala, Box 54, Folder: Guatemala Vol. 2, Memorandums and Miscellaneous, Jan. 1966-Nov. 1968.

${ }^{31}$ El Imparcial, Jan. 17, 1968, pp. 2, 14.

${ }^{32}$ Time Magazine, Jan. 26, 1968, p. 23.

${ }^{33}$ Cesar Montes to the author, Alan Howard, "With the Guerrillas in Guatemala, New York Times Magazine, June 26, 1966, p. 25; Eduardo Galeano, Guatemala: Pais Occupada, pp. 30, 40 .

${ }^{34}$ Gabriel Aguilera, "The Process of Terror in Guatemala," p. 17.

${ }^{35}$ Breen to Assistant Secretary Oliver, "Morale of the Guatemalan Guerrillas," March 3, 1968, LBJ, NSF, Country Files, Guatemala, Box 54, File: Guatemala, Vol. 2, Cables, Jan 1966-Nov. 1968.

${ }^{36}$ Eduardo Galeano, Guatemala: Paix Ocupada, p. 59.

${ }^{37}$ Archbishop Caseriego to Pablo Richard, "Blessing the Powerful: An Interview with Archbishop Caseriego" from Jonathan Fried et al (eds.), Guatemala in Rebellion: A Documentary History, (New York: Grove Press, 1983), p. 221.

${ }^{38}$ McClintock, The American Connection, Vol 2, State Terror and Popular Resistance in Guatemala, (London: Zed Books, 1986), p. 94.

39 Ibid, p. 95; El Imparcial, March 18, 1968, pp. 1, 12; La Hora, March 18, 1968, pp. 1,8 .

${ }^{40}$ Mein to Oliver, "Archbishop's Abduction," March 20, 1968, LBJ, NSF, Country File, Guatemala, Box 54, Folder: Guatemala, Vol. 2, Cables, Jan. 1966-Nov. 1968.

${ }^{41}$ Henry Ginger, "Guatemala is a Battleground," New York Times Magazine, June 16, 1968, p. 14.

42 Ibid, p. 16.

43. "Guatemala: Crisis of the Military," CIA Intelligence Memorandum, May, 1968, LBJ, NSF, Country Files, Guatemala, Box 54, Folder: Guatemala, Vol. 2, Memoranda and Miscellaneous, Jan. 1968-Dec. 1968, pp. 3-5.

${ }^{44} \underline{\text { Ibid, }}$, pp. 7-8.

${ }^{45}$ U.S. Embassy, Guatemala City to Johnson, "Death of the Ambassador," Aug. 28, 1968, LBJL, NSF, country Files, Guatemala, Box 54, Folder: Guatemala, Vol. 2, Cables, Jan. 1966-Nov. 1968. 
46 "Assassination of Ambassador and Further Security Concerns," Aug. 30, 1968, CIA Intelligence Memorandum, LBJ, NSF, Country Files, Guatemala, Box 54, Folder: Guatemala, Vol. 2, Memoranda and Miscellaneous, Jan. 1968-Dec. 1968.

${ }^{47}$ New York Times, August 29, 1968, pp. 1, 16.

${ }^{48}$ Michael Klare and Cynthia Arnson, Supplying Repression: U.S. Support for Authoritarian Regimes Abroad, (Washington, DC: Institute for Policy Studies, 1981), p. 45. 1978, p. 4.

McClintock, The American Connection, p. 96; New York Times, Oct. 18,

so "Guatemala: Crisis of the Military," CIA Intelligence Memorandum, Ibid, p. 81.

${ }^{51}$ McNeill to the author, Carol A. Smith, "The Militarization of Civil Society in Guatemala: Economic Reorganization as a Continuation of War," in Latin American Perspectives (Fall 1990), p. 36.

${ }^{52}$ Richard N. Adams, Crucifixion by Power: Essays on Guatemalan Social Structure 1944-1968, (Austin: Univ. of Texas Press, 1970), p. 423.

${ }^{53}$ Reed to Rostow, "Abolition of the AID-Supported General Studies Program in Guatemala, Aug. 17, 1968, LBJL, NSF, Country Files, Guatemala, Folder: Guatemala Vol. 2, Memoranda and Miscellaneous, Jan. 19968-Dec. 1968.

${ }^{54}$ Breen to Oliver, Oct. 2, 1968, WNRC, RG 286, OPS, Box 63, Folder: Guatemala, General, p. 1.

${ }^{55}$ Sir Robert Thompson, Defeating Communist Insurgency, Experiences form Malaya to Vietnam, (London: Chatto and Windus, 1966), p. 53.

${ }^{56}$ Blase Bonpane, Washington Post, Feb. 2, 1968, p. 26.

${ }^{57}$ Quoted from New York Times, March 8, 1971, p. 8 in Walter La Feber, Inevitable Revolutions, (New York: W. W. Norton, 1984), p. 57. 
"Pamper the army and despise the rest"

Septimus Severus' deathbed advice to his son and successor Caracalla.

\section{CHAPTER VII CONCLUSION}

One of the difficulties in gauging the effects of United States military assistance, doctrine and training on the Guatemalan military and society is the lack of a control group. If one national military or country in Latin America developed without receiving U.S. military assistance, it could be studied and compared with Guatemala. Unfortunately no such army or country existed. In the 1960s the United States funded and trained all the militaries, police forces and nations of Central America, Latin America and the Caribbean. (Costa Rica had no Army but the United States trained and funded its police force.)

Cultural biases can present a problem as well in judging U.S.-Guatemalan military relations. Most Americans tend to view the concept of professionalizing and modernizing a military as depoliticizing it. In fact the American tradition of civilian control over a largely apolitical military is an historical anomaly. It also can be a racist generalization to suppose that there is something intrinsic in the Latin American character that lends itself to military rule. Probably the most professional and modern army of the nineteenth century was the Prussian Army which was deeply involved in the

politics of Germany. By comparison Guatemala's twentieth century military played a less prominent role in its government's affairs prior to the United States massive injection of aid, equipment, training and doctrine in the Kennedy years. 
Another seductive trap in analyzing U.S.-Guatemalan relations is to ascribe everything that occurred in Guatemala solely to outside forces. Many early revisionist historians succumbed to this temptation. According to this scenario, the United States commanded and Guatemala obeyed. Yet it would be an even greater miscalculation to discount the enormous economic, political and military power the United States wielded in the Caribbean in the early 1960s and the huge influence of its Cold War anti-communist ideology on militaries and economic elites in the region. Walter LaFeber in his 1984 Inevitable Revolutions correctly emphasizes the clear historical links from Teddy Roosevelt, Taft and Wilson to FDR, Eisenhower, Kennedy and Johnson in their overall view of the Caribbean as the United States mare nostrum and their consistent opposition to revolution in the region.

Anecdotal examples of the influence of American military indoctrination can be powerful but are they scientific? A Guatemalan-American, Carlos Caranza, who served in his country's military in the 1960s and trained in the United States remembered:

I don't think people here can appreciate what it's like to come from a poor village in Guatemala and at the age of nineteen go to a place like Fort Bragg. It was the greatest thing in my life...I don't think Americans understand how powerful their military is, what a reputation it has as the greatest and strongest Army in the world. Every day at Fort Bragg was like a dream to me to think that I was training and leaming from the richest, most powerful people in the world...The equipment, the money, the food! I don't think my whole country had as much food as was at Fort Bragg...Some of the people didn't like us. They thought they were better than us but I don't think I really even noticed it...At the graduation an important official from the American government came to address us. And all the officers up on the platform in their shiny uniforms and medals with the tanks and armored cars lined up, the band playing and paratroopers jumping into the sky. It was like a miracle. And I thought what an honor it is to be a part of this big fight against the people who were trying to destroy my country, my church and my people. I was sure we would defeat them. How could we not defeat them with the United States on our side? 
Young Turcios Lima expressed similar sentiments before he turned to Communism a few years later. American military indoctrination had no long term effects on him. For the average, barely literate Guatemalan conscript, however, U.S. training must have been a heady and extremely influential experience. Those who questioned U.S. doctrine and anti-communist ideology probably comprised a small minority of the thousands of officers and enlisted men who went through this process. More importantly their senior commanders -- Peralta and Arana -- and the governments they served, enthusiastically subscribed to said doctrine and ideology.

Guatemala was a racist authoritarian society for nearly four centuries before the United States intervened in its affairs significantly in the late nineteenth century. Post-revisionist historians, such as Stephen G. Rabe, Jim Handy and James Dunkerley, have explored the cultural and historical roots of Guatemala's social inequities. Jim Handy convincingly argues that three centuries of Spanish rule in Guatemala proved much more crucial in shaping Guatemalan society than the last hundred years or so of U.S. domination. Yet Guatemalans make a credible argument that they had begun to ascend from their own dark and troubled past during the "ten years of spring," 1944-1954 before anti-communist paranoia in the form of the Dulles State Department and the CIA crushed their small experiment in democracy. While the United States in the 1960 s invested, loaned, and donated enormous sums of money to Guatemala, it did so in ways which best served United States economic interests and favored traditionally U.S. allied elites. Castro undoubtedly posed a real threat to Washington policy-makers in the early 1960 s -- not so much Castro, the military leader, as Castro the example. A good deal of America's economic affluence remained tied to America's favorable 
balance of trade with Latin America -- cheap and vital imports combined with expensive manufactured exports. In 1960, $20 \%$ of all U.S. trade was with Latin America and 25\% of all U.S. investments overseas were concentrated there. But the Kennedy Administration's obsession with counter-insurgency warfare as a solution to the problems of poverty and underdevelopment in Guatemala proved contradictory, self defeating, and ultimately tragic.

Both the Kennedy and Johnson Administrations displayed a palpable sense contempt for Guatemala in their decision, based upon the pretext of a relatively small internal rebellion, to turn the whole country into a counter-insurgency laboratory. In 1963 General Maxwell Taylor stated in a Congressional Hearing on U.S. involvement in South Vietnam:

Here we have an ongoing laboratory where we see subversive insurgency, the Ho Chi Minh doctrine being applied in all its forms. This has been a challenge not only for the armed forces but for several of the agencies of government, as many of them are involved in one way or another in Vietnam. On the military side, however, we have recognized the importance of the area as a laboratory. We have teams out there looking at the equipment requirements of this kind of guerrilla warfare. We have rotated senior officers through there, spending several weeks just to talk to people and get the feeling of the operation so even though not regularly assigned to Vietnam, they are carrying their experience back to their own organizations in other countries. ${ }^{2}$

One of those "other countries" was Guatemala where a disproportionately amount of freshly assigned embassy and military personnel had Vietnam experience. In a September 25, 1968 speech to the Eighth Conference of American Armies in Rio de Janeiro, former Vietnam Commander General William Westmoreland stated:

I am pleased to accept this invitation because as military men, I believe that we, perhaps more than any other profession in the public service, recognize the immediate threat to the countries and people we serve that is posed by the sort of thing which is taking place today in Southeast Asia. We know that South Vietnam is a communist laboratory. We know that if aggression under the guise 
of "national liberation" succeeds there, it is ready to be marketed in our own Hemisphere. ${ }^{3}$

But Guatemala was clearly more of an American than a Communist laboratory. One way to establish proprietorship of a laboratory is to determine who owns the property and the equipment. In 1960 U.S. and other Western investors owned nearly $40 \%$ of the arable land of Guatemala. (The U.S. allied Guatemalan oligarchy owned another $40 \%$.) By the mid-1960s the United States had donated over $\$ 20$ million worth of sophisticated military èquipment to Guatemala -- jet bombers, helicopters, armored personnel carriers, artillery, communication equipment, night vision scopes, machine guns, mortars, sensory devices, and thousands of brand new M-16s. The Guatemalan rebels on the other hand possessed about $300 \mathrm{M}-1$ and M-14 rifles. If Guatemala was Castro's laboratory, it was severely underfunded, under-equipped and understaffed. The proportional ratio of permanent U.S. military advisors to the Guatemalan Army in the 1960s was the highest in the Western Hemisphere (see table).

TABLE XVI"

U.S. Military Advisors to National Armed Forces 1964-1968

$\begin{array}{ll}\text { Argentina } & 1 / 2034 \\ \text { Brazil } & 1 / 1760 \\ \text { Chile } & 1 / 1250 \\ \text { Colombia } & 1 / 1470 \\ \text { Ecuador } & 1 / 2010 \\ \text { Guatemala } & 1 / 300\end{array}$

But this only encompassed permanently stationed advisors within the Embassy's MAAG staff. Hundreds of additional American advisors (MTTs) were flown in during 
crisis periods such as the 1966-7 counter-insurgency war, bringing the ratio up to an almost incredible 1 to 9 .

The United States initially regarded its Guatemalan laboratory an enormous success, a clear cut victory compared to the murky, unsettling results in its Vietnamese lab. U.S. led Guatemala security forces crushed most of the rural insurgency while allied paramilitary forces decimated the urban left. But this "triumph" proved transitory. Turcios Lima and Yon Sosa, the communist guerrilla leaders who had ironically been trained by the U.S., never really established a broad Indian or ladino peasant base in Izabal and Zacapa. By the mid-1970s their successors (Yon Sosa was killed in 1970 by Mexican Police while crossing the border) put together a truly popular based insurgency among the Indians of El Quiche which the Guatemalan military, despite tens of thousands of atrocities and twenty years of fighting, have thoroughly failed to eradicate. Turcios Lima and Yon Sosa fielded about 500 guerrillas in the mid-1960s; the EGP currently maintains 6,000. Indeed the violent counter-terror of 1966-1969 planted the seeds for this new more virulent form of guerrilla revolution. The application of U.S. counter-insurgency doctrine radicalized the Indians, traditionally the most isolated and apathetic group in Guatemalan society.

The United States so lavished the Guatemalan military with equipment, training, advisors, education, money. and technology it virtually assured their becoming the dominant and most cohesive group in Guatemalan society. The corporate nature of the Guatemalan military; its insularism, emphasis on personalism, nepotism and graduate class loyalties contributed to this process, but without U.S. military assistance and political backing, it is difficult to imagine the military running Guatemalan society as it 
has from 1962 to the present as a virtual garrison state. In no other Central American nation has the military held such prolonged endemic and undisputed sway. On two separate occasions in April 1962 and May 1966 the United States exerted its considerable diplomatic pressure to assure Guatemalan military's dominance of the civilian government. In March 1963 the United States conspired with senior Guatemala officers to overthrow an elected government and install an illegal military one, which it recognized eighteen days later.

Did the United States have any credible policy options to simply militarizing Guatemala? All the steps fundamental to meaningful change for Guatemalan society -redistribution of land from the criollos to the Indians, nationalization of Guatemala's natural resources, guaranteeing of full democratic participation for all political parties (including socialists), subsistence farming as opposed to vast two crop agricultural exports, developing a Guatemalan industrial-manufacturing base instead of relying solely on imports from the West, the United States diametrically opposed, some on the grounds of economic self-interest, others due to even deeper ideological beliefs on the sanctity of property, investments and free market superiority over any collectivist solution. In order to bring real freedom and more equitable living standards to Guatemala, the United States purported Alliance for Progress goals, Washington would have had to let Guatemala go and become a sort of Caribbean Switzerland. But the Kennedy Administration believed in holding onto every square inch of the "Free World" in its zero sum game approach to the Cold War and was more than prepared to fight for Guatemala. I. F. Stone explained the political delusions of the Kennedy Administration's main doctrine better than most: 
In reading the military literature on guerrilla warfare now so fashionable in the Pentagon, one feels that these writers are like men watching a dance from outside through heavy plate glass windows. They see the motions but they can't hear the music. They put the mechanical gestures down on paper with pedantic fidelity. But what rarely comes through to them are the injured racial feelings, the misery, the rankling slights, the hatred, the devotion, the inspiration and the desperation. So they do not really understand what leads men to abandon wife, children, home, career, friends and to take to the bush and live gun in hand like a hunted animal; to challenge overwhelming military odds rather than acquiesce any longer in humiliation, injustice, or poverty... ${ }^{5}$

Between 100,000 to 140,000 Guatemalan civilians would die from political violence from 1960 to 1994 , due in no small part to this myopic tunnel vision of counter-insurgency. ${ }^{6}$

The United States' intervention in Guatemala in the 1960s closely mirrored its policy in Vietnam of the same time period and fit in neatly with the larger context of U.S. actions during this stage of the Cold War. As in Vietnam, the United States found itself on the wrong side of nationalism in Guatemala, resented by large segments of the Guatemalan people as a colonial overlord, not the liberal modernizer or concerned political mentor of American rhetoric. In order to prop up an unpopular government, Washington sent enormous amounts of economic and technical aid, military advisors and state of the art weaponry. Civic action, Peace Corps, and charitable programs built "model projects" and strategic hamlets. U.S. advisers at training facilities molded the local army and security forces. American officials launched a concerted effort at "nation building" and "wimning hearts and minds." But by 1965, with the advent of the new Johnson and Mann Doctrines, much of the energy and idealism had dissipated from the Alliance for Progress, from the spirit of Punta del Este. Obsessed with events in Southeast Asia, fiscally constrained by the growing cost of the war there and the Great Society at home, Johnson lost interest in Latin America as a vast social experiment. 
Whereas Kennedy, at least, started out with a dual program of reform and counter-insurgency, Johnson by the mid-sixties in both Vietnam and Guatemala concentrated solely on the latter, indeed on outright conventional war. Kennedy felt the U.S. should kill virulent communists, retain the ability to tear gas and club unruly leftists, yet also strive to prevent Third World peoples, like the Vietnamese and the Guatemalans, from becoming communists in the first place through social improvements and western style economic prosperity. Saddled with the abject failure of the Kennedy Doctrine to achieve any substantial results in these areas, Johnson simply unleashed the vast killing machine of the modern American military to cut down all real and potential enemies in both nations. Claymores, helicopter gunships, and airborne units, replaced Green Beret advisers and esoteric theories of the stages of economic growth. To paraphrase General Sheridan for the Johnson Administration, the only good Third World Communist was a dead Third World Communist. Yet in all fairness to Johnson, his policies were only the logical result of his predecessor's miscalculations and willful blindness to the realities of the Third World.

The Kennedy and Johnson White Houses made some undeniable efforts to institute improvements and local development projects in Guatemala, but the bulk of their foreign policy emphasis always rested with the elites and the security forces. The United States never really trusted a democratically elected liberal politician -- be it Jacobo Arbenz in the 1950 s or Mendez Montenegro in the 1960 s to govern Guatemala. A 1962 State Department telegram entitled: "Guatemala: Guidelines for Policy and Operations" clearly stated the U.S. political objectives.

1. The prevention of the ascension to power of Communists in Guatemala. 
2. The continuance if possible within the framework of objective no. 1 of a legally established constitutional government. ${ }^{7}$

By the very nature of its command structure and its intrinsic legitimization of violence, the military profession was not a good training ground for the techniques and processes of negotiation, consensus building and bargaining so necessary for effective democratic political leadership. Nonetheless obsessed with objective number one, the Kennedy and Johnson Administrations bet on an Army and not an Alliance for Progress in Guatemala. 


\section{CHAPTER VII FOOTNOTES}

${ }^{1}$ Carlos Caranza to the author, January 10, 1995.

2 cited in Michael Klare War Without End, (New York: Alfred Knopf, 1977), p. 49 from Subcommittee of the House Committee on Appropriations, Hearing on Department of Defense Appropriations for 1964, Part 1, February 13, pp. 483-84.

${ }^{3}$ cited in Thomas and Marjorie Melville, Guatemala -- Another Vietnam?, (London: Penguin Books, 1971), p. 288.

4 Andre Ronquie, The Military and the State in Latin America, (Berkeley: University of California Press, 1987), p. 133.

5 I. F. Stone, In Time of Torment, (New York: Random House, 1968), pp. $173-4$.

6 "Abandoning the Victims," The UN Advisory Services Program in Guatemala, Feb. 1990, p. 6.

${ }^{7}$ Guatemala Guidelines for Policy and Operations," Nov. 30,1962, JFKL, NSF, Country Files, Guatemala, Box 101, Folder 4, Guatemala, General, July 1962-Dec. 1962. 


\section{BIBLIOGRAPHY}

\section{Archival Sources:}

Lyndon Baines Johnson Library, National Security Files, Country Files, Guatemala 1963-1969.

John F. Kennedy Library, National Security Files, Country Files, Guatemala 1961-1963.

John F. Kennedy Library, Presidential Office Files, Country Files, Guatemala 1961-1963.

John F. Kennedy Library, Department of Defense Files and Regional Security Files, Latin America 1961-1963.

John F. Kennedy Library, Alliance for Progress Files, 1961-1963.

National Archives, Office of Public Safety, Country Files, Guatemala 1957-1974.

Office of Public Safety Records 1957 - 1974. National Archives, Washington, DC.

\section{Government Publications:}

Department of State Bulletins. 1954 -1969.

Foreign Relations of the United States: The American Republics, 1944-1964.

Washington: United States Government Printing Office, 1968, 1983.

Johnson, Kenneth F. The Guatemalan Presidential Election of March 6, 1966: An Analysis. Washington, DC: GPO, 1968.

The Speeches of John F. Kennedy, Presidential Campaign of 1960. Washington, DC: GPO, 1961.

The Speeches of John F. Kennedy: The White House Years. Washington, DC: GPO, 1964.

U.S. AID "Office of Public Safety Termination Phase-Out Report." Washington, DC: GPO, 1975. 


\section{Articles:}

"Abandoning the Victims." The UN Advisory Services Program in Guatemala. Feb., 1990.

Adams, Richard N. "The Guatemalan Military." Studies in Comparative International Development. Vol 4. No. 5. (March 1968), pp. 97-120.

Aguilera Peralta, Gabriel. "The Militarization of the Guatemalan State" from Fried, Jonathan, ed., Guatemala in Rebellion: A Documentary History. New York: Grove Press, 1983.

" Terror and Violence as Weapons of Counter-insurgency in Guatemala." Latin American Perspectives. (Spring-Summer 1980), pp. 103-125.

"The Process of Terror in Guatemala" in Central America: A Contemporary Crisis LARU Studies. vol. V, No. 1. (September 1982), pp. 3-21.

Ahmad, Eqbal. "The Theory and Fallacies of Counterinsurgency." The Nation. Aug. 2, 1971, pp. 70-85.

Angel Albizurez, Miguel. "The Oligarachy and the Kennedy Administration in Guatemala." Latin American Perspectives. Vol. 49. (Spring and Summer 1972), pp. 61-77.

Black, George. "Central America: Crisis in the Backyard." New Left Review. No. 135 (Sept. - Oct. 1982), pp. 20-42.

Castano, Camila. "Avec les Guerrilles de Guatemala." Partisans. No. 38. (July-Sept. 1967), pp. 128-153.

Collazo-Davila, Vincente. "The Guatemalan Insurrection" from O'Neill, Bard E., ed. Insurgency in the Modern World. Boulder: Westview Press, 1980.

de Coro, Alejandro. "Los commissionados militares en Guatemala, 1963-1966." Estudios Centroamericanas. Vol. 17, No. 7. (Spring 1972), pp. 43-59.

Crain, David A. "Guatemala Revolutionaries and Havana's Ideological Offensive of 1966-1968." Journal of Inter-American Studies. Vol. 17. No. 2. (Spring 1975), pp. 183-197.

Duncan, Donald. "The Whole Damned Thing is a Lie." Ramparts Vol. 9, No. 6 (Sept. 1969), pp. 38-52. 
Fisher, Albert L. "To Beat the Guerrillas at Their Own Game." Military Review. Vol. XIX, No. 5. (Dec. 1963), pp. 73-91.

Francis, Michael J. "Military Aid to Latin America in the U.S. Congress." Journal of Inter-American Affairs, Vol. 6, No. 3 (July 1964), pp. 389-404.

Gilly, Adolfo. "The Guerrilla Movement in Guatemala." Monthly Review. Vol. 17, No. 1. (Dec. 1965), pp. 21-49.

Hildebrand, John R. "Latin American Economic Development, Land Reform and U.S. Aid with Special Reference to Guatemala." Journal of Inter-American Studies 4 (July 1962), pp. 354-368.

Howard, Alan. "With the Guerrillas in Guatemala." New York Times Magazine. June 26, 1966., pp. 8-9, 16, 18, 20, 33, 35.

"Human Rights Development in Guatemala." Human Rights Watch World Report. 1993.

"Human Rights in Guatemala." National Academy of Sciences on Human Rights: 1992 Report of a Delegation.

Jenkins, Brian and Sereseres, Cesar D. "U.S. Military Assistance and the Guatemalan Armed Forces." Armed Forces and Society. Vol. 3, No. 4. (Aug. 1977), pp. 575-594.

"Little Hope: Human Rights in Guatemala January 1984 to January 1985." An Americans Watch Report. Feb., 1985.

Menchu, Rigubenta. "In Guatemala We Indians Have No Childhood" from Fried, Jonathan, ed. Guatemala in Rebellion: A Documentary History. New York: Grove Press, 1983.

Montes, Cesar. "Una ruptura logica y necesaria", Punto Final. Vol. 3, No. 23. (April 23, 1968), pp. 37-53.

Nairn, Allan. "Bank of America Asked to Explain Its Support for the Guatemala Death Squads." Multinational Monitor. (March 1972), pp. 12-19.

"To Defend Our Way of Life: An Interview with a U.S. Businessman" from Fried, Jonathan L., ed. Guatemala in Rebellion: A Documentary History. New York: Grove Press, 1983.

Payeras, Mario. "Guatemalan Army and U.S. Policy. Monthly Review. Vol 37, no. 10. (March 1987), pp. 14-20. 
Perlmutter, Amos. "The Praetorian State and the Praetorian Army." Comparative Politics. Vol. 1, No. 3 (April 1969)

Pye, Lucien, W. "Roots of Insurgency and Commencements of Rebellions in Eckstein, Henry. Internal War: Problems and Approaches. New York: Face Press, 1964.

Rabe, Stephen G. "Clues Didn't Check Out: Commentary on the CIA and Castillo Armas." Journal of Diplomatic History. Vol. 14, No. 1, pp. 67-95.

"Controlling Revolutions: Latin America the Alliance for Progress and Cold War Anti-Communism" from Paterson, Thomas G., ed. Kennedy's Quest for Victory: American Foreign Policy 1961-1963. New York: Oxford University Press, 1989.

Rogers, Robert and Yates, Ted. "The Undeclared War in Guatemala." Saturday Evening Post. June 18, 1966, pp. 30-33.

Saxe-Fernandez, John. "The Central American Defense Council and Pax Americana," from Horowitz, Irving Louis, ed. Latin American Radicalism. New York: Random House, 1969, pp. 68-93.

Smith, Carol A. "The Militarization of Civil Society in Guatemala: Economic Reorganization as a Continuation of War." Latin American Perspectives. (Fall 1990), pp. 8-41.

Streeter, Stephen M. "Reform or Revolution: The Alliance for Progress in Guatemala" (a paper presented at the Southwestern Social Science Association, March 17-20, 1993 at New Orleans, Louisiana).

Torres-Rivas, Edelberto. "Guatemala: Crisis and Political Violence." Latin America 1970: NACLA Report on the Americas. Vol. 2, XIV, No. 1. (Jan.-Feb. 1970), pp. 51-63.

"Seven Keys to Understanding Central America" from Wiarda, Howard J., ed. Rift and Revolution: The Central America Imbroglia. Washington, DC: American Enterprise for Public Policy Research, 1984.

Walker, William O. III. "Mixing the Sweet with the Sour: Kennedy, Johnson, and Latin America" from Kunz, Diane B., ed. The Diplomacy of the Crucial Decade: American Foreign Relations During the 1960s. New York: Columbia University Press, 1994.

Weaver, Jerry L. "The Political Style of the Guatemalan Military Elite." Studies in Comparative Political Development. Vol. V. (1969-1970), pp. 47-71.. 
"The Military Elite and Political Control in Guatemala, 1963-1966."

Social Science Quarterly. Vol. 50, No. 1. (June 1969), pp. 127-135.

Wickham-Crowley, Timothy P. "Winners, Losers and Also-Rans: Towards a

Comparative Sociology of Latin American Guerrilla Movements" from Eckstein, Susan, ed. Power and Popular Protest in Latin America. Berkeley: University of California Press, 1988.

Yates, Lawrence. "The United States and Rural Insurgency in Guatemala 1960-1970: An Inter-American 'Success Story?"' from Woodward, Ralph Lee Jr. Central America: Historical Perspectives on the Contemporary Crisis. New York: Greenwood Press, 1988.

Yurrita, Alfonso. "The Crisis of the Established Order in Guatemala" from Goodman, Louis W., ed. The Military and Democracy in Central America. Lexington: Lexington Books, 1990.

\section{Books and Dissertations:}

Adams, Richard. Guatemala: Crucifixion by Power. Boulder, Colo.: Westview Press, 1973.

Alba, Victor. Alliance Without Allies: The Mythology of Progress in Latin America. New York: Praeger, 1965.

Arevalo, Juan Jose. The Shark and the Sardines. New York: Lyle Stuart Co., 1963.

Barber, Willard F. and Ronning, C. Neale. Internal Security and Military Power: Counterinsurgency and Civic Action in Latin America. Columbus: Ohio State University Press, 1966.

Berry, Tom Dollars and Dictators: A Guide to Central America. New York: Grove Press, 1983.

Berry, Tom and Preusch, Deb. The Central American Fact Book. New York: Grove Press, 1986.

Black, George. Garrison Guatemala. New York: Monthly Review Press, 1985.

Blaufarb, Douglas. The Counter-insurgency Era: U.S. Doctrine and Performance, 1950 to the Present. New York: Free Press, 1978.

Blum, William. The CIA: A Forgotten Documentary History. London: Zed Books, 1986. 
Bonpane, Blase. Guerrillas of Peace. Boston: South End Press, 1985.

Burbeck, Roger and Flynn, Patricia. Agribusiness in the Americas. New York: Monthly Review Press, 1980.

Carmack, Robert M. Harvest of Violence. Norman: University of Oklahoma Press, 1988.

Chilcote, Ronald H., ed. Radical Thought in Latin America. Boulder: Westview Press, 1991.

Cook, Blanche. Declassified Eisenhower. Garden City, NY: Doubleday, 1981.

de Coro, Alejandro. Guatemala: la volencia. Mexico City: Nuestro Times, 1968.

Davis, Shelton and Hudsen, Julie. Witness to Political Violence in Central America. Boston: Oxfam America, 1982.

Dunkerly, James. Power in the Isthmus: A Political History of Central America. London: Verso, 1988.

Eisenhower, Dwight D. Waging Peace. Garden City, NY: Doubleday, 1965.

Etchison, Don L. The United States and Militarism in Central America. New York: Praeger, 1975.

Eulerman, Kenneth M. and Herring, George C., eds. The Central American Crisis: Sources of Conflict and the Failure of U.S. Policy. Wilmington, DE: Scholarly Resources Inc., 1988.

Fitzsimons, Louise. The Kennedy Doctrine. New York: Random House, 1972.

Fried, Jonathan L., Ed. Guatemala in Rebellion: A Documentary History. New York: Grove Press, 1985.

Galeano, Eduardo. Guatemala: Pais Ocupado. Mexico City: Nuestro Tiemeo, 1969.

Gleijses, Piero. Guatemala: Perspectives of a Regime's Transformation. Bonn: Friedrich Ebert Stiftuns, 1981.

Gott, Richard. Guerrilla Movements in Latin America. London: Thomas Nelson, 1970.

Handy, Jim. Gift of the Devil: A History of Guatemala. Boston: South End Press, 1984. 
Hanson, Simon G. Five Years of the Alliance for Progress: An Appraisal.

Washington: Inter-American Affairs Press, 1967.

Harnecker, Marta. Pueblos en Armas Managna. Nueva Nicaragua, 1983.

Immerman, Richard H. The CIA in Guatemala: The Foreign Policy of Intervention. Austin: University of Texas Press, 1982.

Jonas, Susanne. The Battle for Guatemala: Rebels, Death Squads and U.S. Power. San Francisco: Westview Press, 1991.

Jonas, Susanne and McCaughan, Ed. Guatemala, Tyranny on Trial: Testimony of the Permanent People's Tribunal. San Francisco: Synthesis Publications, 1985.

Jonas, Susanne and Tobis, David, eds. Guatemala. New York: NACL, 1974.

Klare, Michael T. and Arnson, Cynthia. Supplying Repression: U.S. Support for Authoritarian Regimes Abroad. Washington, DC: Institute for Policy Studies, 1981.

Kunz, Diane B., ed. The Diplomacy of the Crucial Decade: American Foreign Relations During the 1960s. New York: Columbia University Press, 1994.

LaFeber, Walter. Inevitable Revolutions: The United States in Central America. New York: W. W. Norton and Company, 1984.

Landau, Saul The Guerrilla Wars of Central America: Nicaragua, El Salvador, and Guatemala. New York: St. Martins Press, 1993.

Larteguy, Jean. Los Guerrilleros. Mexico City: Raoul Solar, 1970.

Lieuwen, Edwin. Arms and Politics in Latin America. New York: Praeger, 1961.

Generals vs. Presidents: Neo-Militarism in Latin America. New York: Praeger, 1965.

Lowenthal, Abraham F. and Fitch, Samuel J. Armies and Politics in Latin America. New York: Holmes and Meier, 1986.

Manz, Beatrice. Refugees of a Hidden War: The Aftermath of Counter-insurgency. New York: University of New York Press, 1988.

Martinez Polquez, Severo. La Patric del Criollo. San Jose, Costa Rica: Editorial Universitania Centroamericana, 1979. 
McClintock, Michael. The American Connection, State Terror and Popular Resistance in Guatemala. London: Zed Books, 1985.

Instruments of Statecraft: U.S. Guerrilla Warfare, Counterinsurgency and Counterterrorism 1940-1990. New York: Pantheon Books, 1992.

McNeil, Frank. War and Peace in Central America. New York: Charles Scribner, 1988.

Melville, Thomas and Melville, Marjorie. Guatemala: The Politics of Land Ownership. New York: The Free Press, 1971.

Penquin Books, 1971.

Guatemala-Another Vietnam? Harmondsworth:

Minoff, Bruce. Pragmatic Illusions: The Presidential Politics of John F. Kennedy. New York: David McKay, 1976.

Paterson, Thomas G., ed. Kennedy's Quest for Victory: American Foreign Policy 1961-1963. New York: Oxford University Press, 1989, pp. 70-85.

Phillips, David Atlee. The Night Watch. London: Robert Hale, 1978.

Prados, John. The Presidents' Secret Wars: CIA and Pentagon Covert Operations Since World War Two. New York: William and Morrow, 1986.

Rabe, Stephen G. Eisenhower and Latin America: The Foreign Policy of Anti-Communism. Chapel Hill: University of North Carolina Press, 1988.

Revel, Jean-Francois. How Democracies Perish. Garden City, NY: Doubleday, 1984.

Rouquie, Alain. The Military and the State in Latin America. Berkeley: University of California Press, 1987.

Schlesinger, Stephen and Kinzer, Stephen. Bitter Fruit: The Untold Story of the American Coup in Guatemala. Garden City, NY: Anchor Press, 1983.

Sereseres, Cesar D. "Military Development and the U.S. Military Assistance Program for Latin America: The Case of Guatemala." Ph.D. dissertation, University of California, Riverside, 1971.

Sloan, John W. "The Electoral Gam in Guatemala." Ph.D dissertation, University of Texas at Austin, 1970. Department of Political Science.

Steel, Ronald. Pax Americana. New York: Viking Press, 1967. 
Stone, I.F. In a Time of Torment. New York: Random House, 1968.

Streeter, Stephen M. "Managing the Counter-Revolution: The United States and Guatemala, 1954-1961." Phd dissertation. University of Connecticut, Storrs, 1994.

Thompson, Sir Robert. Defeating Communist Insurgency, Experiences from Malaya to Vietnam. London: Chetto and Windus, 1966.

Toriello Garrido, Guillermo. Guatemala, Mas de 20 anos de traicion. Caracas: Editorial Altereo de Caracas, 1980.

Walton, Richard J. Cold War and Counterrevolution: The Foreign Policy of John F. Kennedy. New York: Viking Press, 1972.

Wright, Thomas C. Latin America in the Era of the Cuban Revolution. New York: Praeger, 1991.

Wythe, George. The United States and Inter-American Relations: A Contemporary Appraisal. Gainesville: University of Florida Press, 1965.

Ydigoras Fuentes, Miguel. My War with Communism. Englewood Cliffs, New Jersey: Prentice Hall, 1963.

\section{Newspapers:}

Chicago Daily News. December 1966.

El Imparcial. 1960-1969.

La Hora. 1960-1969.

Miami Herald. 1966.

New York Times. 1960-1969.

Prensa Libre. 1960-1969.

Washington Post. 1964-1969. 